U. S. DEPARTMENT OF THE INTERIOR

FORTY-FIFTH ANNUAL REPORT OF THE DIRECTOR OF THE GEOLOGICAL SURVEY TO THE SECRETARY OF THE INTERIOR FOR FISCAL YEAR ENDED JUNE 30, 1924 
DEPARTMENT OF THE INTERIOR

HUBERT WORK, Secretary

UNited States Geological SURVEY George Otis SMith, Director

\section{FORTY-FIFTH ANNUAL REPORT}

OF THE

\section{DIRECTOR OF THE UNITED STATES GEOLOGICAL SURVEY \\ TO THE}

\section{SECRETARY OF THE INTERIOR}

FOR THE FISCAL YEAR

ENDED JUNE 30

1924

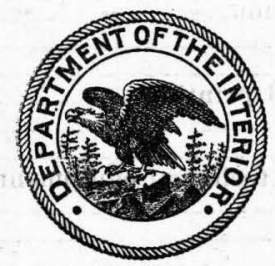

WASHINGTON

GOVERNMENT PRINTING OFFICE 


\section{Directors of the U. S. Geological Survey}

\section{CONTENTS}

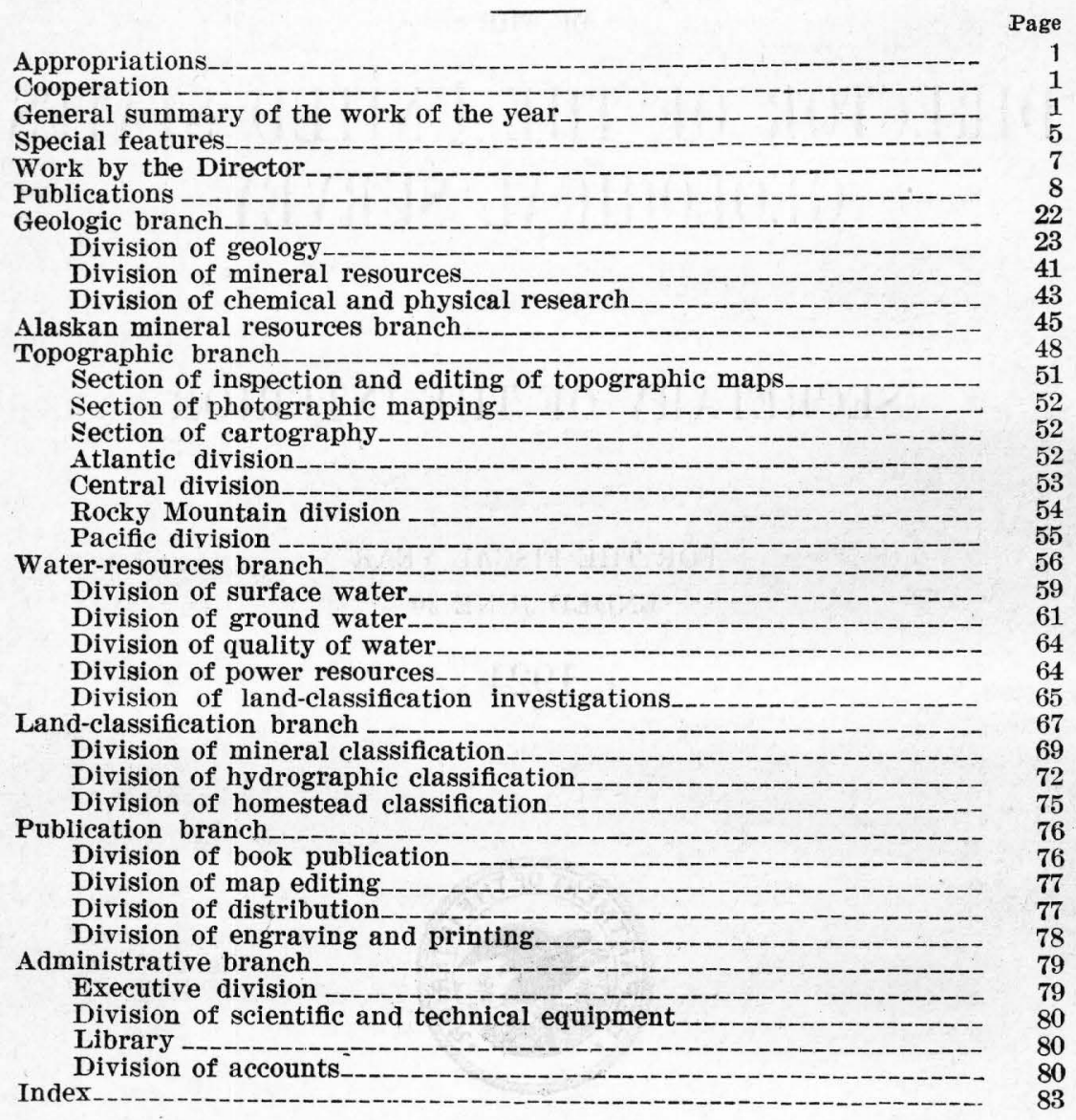

\section{ILLUSTRATION}

PLATE I. Areas covered by topographic surveys made by United States Geological Survey prior to July 1, 1923 


\title{
FORTY-FIFTH ANNUAL REPORT OF THE DIRECTOR OF THE UNITED STATES GEOLOGICAL SURVEY
}

\author{
George Otis Smith, Director
}

\section{APPROPRIATIONS}

The appropriations made directly for the work of the Geological Survey for the fiscal year 1924 included 11 items, amounting to $\$ 1,670,190$. In addition $\$ 110,000$, to be disbursed under the direction of the Public Printer, was appropriated for printing the reports of the Survey and allotments of $\$ 10,000$ for miscellaneous printing and binding and of $\$ 4,280$ for miscellaneous supplies were made to the Survey from appropriations for the Interior Department.

A detailed statement of the amounts appropriated and expended is given at the end of this report.

\section{COOPERATION}

Cooperation with States was continued in general accordance with the plans followed for many years. Thirty-six States thus shared in the cost of the geologic, topographic, and hydrologic work of the Survey. This form of cooperation is not only of mutual pecuniary advantage to State and Nation but serves to maintain that relation between the two which is the ideal of American government. Counties and municipalties also participated in this cooperative work. The total amount expended in such cooperative work during the year was $\$ 600,000$. Cooperation was also continued with other bureaus of the Government service. Funds aggregating $\$ 184,720$ were placed to the credit of the Geological Survey for work done by it for other Government bureaus and offices.

\section{GENERAL SUMMARY OF THE WORK OF THE YEAR.}

The work of the Geological Survey during the fiscal year 1924 is set forth in detail in this report in the statements of work done by its several branches. A brief itemized summary of the principal features of the work is given below.

\section{WORK IN GEOLOGY}

Made geologic surveys in 44 States and in Alaska, the work done including geologic mapping, determinations of stratigraphy, structure, and geologic history, and examinations of mineral resources.

Made studies in 8 States to determine the prospects of obtaining on or gas, and prepared reports showing the results of the studies. 
Continued laboratory work to discover the sources of petroleum and the mode of its formation and the features of oil sands-such as texture and porositythat are favorable to the accumulation of petroleum.

Made researches in the field and the laboratory to determine the mode of formation of oil shale.

Continued to assist the United States Coal Commission by furnishing facts concerning the coal regions.

Continued cooperation with the General Land Office, the Indian Office, and the Forest Service in the examination and classification of public lands, the work being done especially to determine whether they contain oil, gas, or other mineral deposits.

Examined coal fields in 6 States, prepared 8 reports ( 4 for publication elsewhere), and published 3 reports and 4 press notices on fields examined.

Made cooperative field studies of ore deposits, coal beds, and geologic formations with 12 States.

Made special studies of metalliferous deposits in Michigan and California with a view to the broader application of the results.

Continued the search for deposits of potash and found deposits in southwestern Texas that promise to be of commereial value.

Made field investigations to determine resources of arsenic in Western States.

Made geologic examinations of sites for dams and reservoirs in Western States in cooperation with the Bureau of Reclamation, to determine the strength, imperviousness, and other features of the rocks.

Completed cooperative field work on a geologic map of Arizona, to be published by the State, and completed oflice work on a geologic map of Wyoming, now in preparation for publication.

Aided in completing and publishing a report on the geology of Haiti, the cost of which was borne by the Haitian Government.

Identified thousands of fossils sent in from different parts of the United States and from the West Indies and Central and South America, for stratigraphic determination and correlation, principally as a means of discovering the geologic horizons at which oil may be found.

Continued to study the San Andreas earthquake rift in California in cooperation with the Seismological Society of America, the Carnegie Institution, and the Coast and Geodetic Survey.

Published 30 reports on the geologic features and mineral resources of areas in different parts of the United States.

\section{WORK ON MINERAI RESOURCES}

Collected and published statistics of mineral production and cooperated in this work with 16 States and the Bureau of the Census.

Assisted the United States Coal Commission to the date of its termination, maintained contact with the Department of Commerce in its studies of special features of the coal industry, and made and reported on four canvasses of consumers' stocks of coal in cooperation with the Bureau of the Census.

Issued weekly reports showing the production of coal, prepared and published monthly statements on the production of petroleum, and compiled for the Federal Trade Commission special statistical reports on petroleum.

Prepared a map showing petroleum and natural-gas fields and petroleum pipe lines in Texas.

Continued the compilation of data showing mineral production in foreign countries and the world's fuel reserves.

WORK IN CHEMISTRY AND PHYSICS

Made 782 quantitative analyses of rocks and minerals and identified 2,698 mineral specimens.

Made laboratory studies to determine the mode of formation of metallic copper in ore deposits.

Made studies of the chemical nature of the organic matter in oil shale in onder to discover the mode of formation of petroleum and other natural hydrocarbons.

Made a series of assays for determining the presence of small quantities of platinum in rocks.

Made 662 analyses of potash salts in material from Texas, disclosing promising potash-rieh beds. 
Measured deep earth temperatures and temperatures of hot springs in a study of the temperatures at depths in the earth's crust.

Made laboratory studies of the texture, pore space, and productivity of oil sands.

$$
\text { WORK IN ALASKA }
$$

Continued the survey of Naval Petroleum Reserve No. 4, traversing areas aggregating 220 linear miles along six rivers and exploring the lower part of Wainwright Inlet, mapping 2,150 square miles in northern Alaska.

Made reconnaissance geologic surveys elsewhere in Alaska covering 8,570 square miles and reconnaissance topographic surveys covering 4,300 square miles.

Continued the study of the copper deposits of Prince William Sound and of the geology and mineral resources of southeastern Alaska, especially the Hyder district, and of the nickel deposits in the Sitka district.

Continued the study of the stratigraphy of Alaska Peninsula, especially the Cold Bay petroleum field and the Chignik district.

Completed a report on the Mesozoic geology of Alaska.

Continued an examination of the ore deposits and other mineral resources in the region along the Alaska Railroad and prepared and published a report (Bulletin 755-C) giving its results.

Completed a study of the Tertiary flora of Alaska and assembled the results in form for early publication.

Revised for republication the geographic dictionary of Alaska.

Published a report on work done in Alaska in 1921, three chapters of a similar report on work done in 1922, and a bulletin on the Ruby-Kuskokwim region.

Published a large relief map of Alaska in which the topographic features are brought out by brown shading and the water features are shown in blue.

\section{TOPOGRAPHIC WORK}

Surveyed for mapping $\mathbf{1 6 , 0 2 1}$ square miles in the United States, resurveyed. 644 square miles, and made river profile surveys covering 818 linear miles, running in connection with these surveys 7,781 linear miles of primary levels and setting 2,059 permanent bench marks.

Occupied 177 triangulation stations, of which 122 were permanently marked.

Ran primary traverse lines aggregating 5,832 miles and in connection therewith set 1,450 permanent marks.

Completed 696 square miles of topographic surveys in Hawaii, the work including the running of 228 miles of primary levels and the establishment of 90 bench marks.

Compiled for the air service of the United States Army air-route maps of more than 100,000 square miles of territory.

Prepared maps of proposed dam sites on Colorado River and a map of Arizona showing their location.

Assembled and redrafted reconnaissance maps of streams in Colorado and Wyoming and made a series of maps of Missouri River.

Continued cooperation in topographic surveys with 19 States and with Hawaii and performed base-map work for the National Park Service, the United States Coal Commission, the General Land office, and the Federal Board for Vocational Education.

Published editions of 70 new topographic maps that form sheets of the Topographic Atlas of the United States (including shaded relief editions of 7 standard maps), maps of Alabama and Arizona, a shaded relief map of Kentucky, and photolithographic editions of 92 new maps (to be engraved later), of 34 maps not yet scheduled for engraving, and of 17 river plans and profiles.

Published a bulletin (No. 709) giving in one volume the results of triangulation in the United States in 1916-1918.

Published a bulletin (No. 689) describing the boundaries, areas, geographic centers, and altitudes of the United States and the several States.

WORK ON WATER RESOURCES

Continued stream gaging at more than 1,600 stations on rivers in 41 States and in Hawaii to determine the quantities of water available for irrigation, power, and other uses, performing part of the work in cooperation with 29 
States and Hawaii and with the Bureau of Reclamation, Forest Service, National Park Service, Office of Indian Affairs, Federal Power Commission, Office of the Chief of Engineers, and city of San Francisco.

Made investigations of ground water in 16 States, cooperating in this work in certain areas with 5 States, the Bureau of Reclamation, and the General Land Office.

Analyzed 819 samples of water and made studies to improve methods of water analysis.

Prepared monthly reports on the production of electricity and the consumption of fuel by public-utility power plants and on the stocks of coal on hand at such plants and a report on the developed water power of the United States.

Made surveys of all promising dam sites along Colorado River from Lees Ferry to the lower end of Black Canyon and began the preparation of a report showing the results of the work done.

Made examinations of power sites, proposed power developments, the powervalue of streams and lands, and the use of water for power and irrigation in 8 States, these examinations including sereral items of work done for the Federal Power Commission.

Continued examinations of public lands for classification under the enlarged and stock-raising homestead laws, performing such work in 18 States and covering areas embraced in about 2,000 applications.

WORK IN CIASSIFICATIOX OF PUBLIC LAXDS

Classified 1,812,685 acres of public land as coal land and 4,105 acres as oil land and made other classifications involving a net decrease of $2,998,210$ acres in areas withdrawn as possible coal land and of 421,723 acres in areas withdrawn as possible oil land.

Reported on 14,782 cases arising under the administration of the public-land laws.

Reported on 6,282 applications made for permits, leases, or patents under the mineral-land laws.

Recommended the addition of 153,052 acres to the power-site reserves and the elimination of 58,537 acres.

Increased the area withdrawn under the Nerada ground-water reclamation act from $1,300,940$ acres to $1,425,060$ acres.

Recommended designations involving $1,379,449$ acres of land arailable for settlement under the enlarged-homestead acts and the cancellation of designations involving 12,379 acres.

Recommended the addition of 107,384 acres to the public water reserves and the elimination of 6,783 acres.

Recommended the designation of 1,801,441 acres as stock-raising homestead land and the cancellation of designations covering 760 acres.

\section{WORK IN PRINTING AND PUBLICATION}

Edited and otherwise prepared for printing 27,981 pages of manuscript, read and corrected 2,306 galley proofs and 15,928 page proofs, and prepared indexes for 25 reports covering 4,455 pages.

Prepared for reproduction in reports 4,442 illustrations.

Edited for engraving 90 new topographic maps, edited for reprint 222 topographic maps, edited 54 plan and profile river survey sheets for photolithographic reproduction, edited 249 maps for incorporation in Survey reports, and read proofs of 613 maps.

Published 114 reports containing 14,543 pages in editions amounting to 351,107 copies, 4 geologic folios in editions amounting to 15,485 copies, and 92 new or revised topographic maps and 203 reprinted maps in editions amounting to $1,339,173$ copies.

Distributed 521,548 books and pamphlets, 16,681 geologic folios, 923 copies of the World Atlas of Commercial Geology, and 735,573 maps, a total of 1,274,725 publications, of which 617,391 were sold.

Engraved and printed 70 new maps and completed the engraving for 32 new maps, photolithographed and printed 92 new maps, made corrections on the engraved plates for 214 maps, and reprinted editions of 193 maps and of 10 corrected State and other photolithographed maps.

Printed for other branches of the Government or for incorporation in reports in the Geological Survey $4,655,982$ copies of maps, plans, sections, ete., the work involving more than $23,000,000$ impressions. 
OTHER WORK

Maintained a photographic laboratory, making an output of 11,279 negatives, 1,609 lantern slides, 111,037 prints, and other material.

Maintained a geologic library, receiving 14,655 books, pamphlets, periodicals, and maps, affording facilities for 12,908 readers, and lending for use outside of the library 7,054 books and maps.

Received 348,361 letters and other pieces of mail, sent out 883,179 pieces, and handled 3,505 pieces of freight and express outgoing and incoming.

\section{SPECIAL FEATURES}

To catalog the activities or even the accomplishments of the year is not enough: special mention needs to be made of a few outstanding items in the record. To stress these may serve both to set forth the nature of the public service rendered by this scientific bureau and to link up its present-day activities with what had been done earlier.

The Colorado Canyon expedition, which attracted some public attention, well exemplifies the success won by uniting specially trained topographic, hydraulic, and geologic engineers in a carefully planned and skillfully executed effort. This traverse of the Grand Canyon completed the instrumental surveys of Colorado River that had been begun 12 years before at Kremmling, in northern Colorado. The mapping of 253 miles of canyons and the examination of 22 possible dam sites during the year was a task fraught with danger, but the Government engineers regarded the danger as only " in the day's work" of scientific exploration. Colonel Birdseye and his associates carried on the traditions of the field service, for the second Director, Major Powell, had made the first boat trip through the Grand Canyon in 1869. This thorough survey of the Colorado and its principal tributaries is the necessary preliminary to the making of Federal and State plans for the full utilization of the natural resources in a region where water gives value to land.

Equally noteworthy and equally spectacular are the exploratory expeditions into Arctic Alaska, the first made in the summer of 1923 and the second started in the following winter. This geologic examination of the naval petroleum reserve in northern Alaska has been undertaken at the request of the Secretary of the Navy to determine the possibility of finding oil in quantities sufficient to add materially to the reserves for the future use of the Navy, if not indeed large enough to augment the Nation's supply for other needs. The first season's examination along the Arctic coast of Alaska verified the reports of large seepages of oil and of geologic conditions sufficiently favorable to oil accumulation to warrant the second expedition, which started northward with dog sledges from the Yukon in February last and had crossed the Endicott Range by March. The area to be traversed and mapped by the three parties of this expedition is roughly 3,700 square miles and includes the largest tract of unexplored United States territory. Dr. Philip S. Smith is the geologist in charge of this exploration, and his plans for it were made 13 years before, when he was working on the southern margin of the area.

This search for an oil field in Aretic Alaska illustrates the emphasis now put on geologic work in the exploitation of fuel resources, but 
the nature of the exploration and the experienced personnel available for it fittingly mark the status of the Geological Survey's work in Alaska after 25 years of uninterrupted effort. In the quarter of a century since 1898 slightly more than $\$ 2,000,000$ has been appropriated for the investigation of the mineral resources of Alaska, and by this means over one-fifth of the area of the Territory has been covered by reconnaissance geologic surveys and more than onequarter of the area by reconnaissance topographic surveys. Exploratory surveys over many thousands of square miles and visits to hundreds of mining camps, large and small; maintenance of scores of stream-gaging stations; and the publication of 420 maps and 383 reports are other items in the systematic scientific investigations carried on in this outlying territory-the whole making up a record of consistent promotion of Alaskan interests in which the Department. of the Interior may take justifiable pride. Since July, 1903, Alfred $\mathrm{H}$. Brooks has been in active charge of the work, and he has become the recognized authority on the geography, geology, and resources of Alaska, but the credit for what has been accomplished he would wish to divide among his associates, some 120 geologists and engineers who have shared in this pioneering work.

The Director's service as a member of the United States Coal Commission ended on September 22, and he resumed his duties with the Survey on September 24. This connection of the Survey with the special investigation assigned to the commission was the logical outcome of the particular attention given to the country's resources in coal ever since the Geological Survey undertook the technical supervision of the statistical study of the coal industry for the census of 1880 , and especially since the general review of the coal fields made 20 years later and fully summarized in Part III of the Twenty-second Annual Report. The geologic and economic studies of the coal resources of the country to an increasing extent engaged the attention of Federal geologists and statisticians until the Geological Survey had become the largest single repository of facts relating to the coal industry, and of this accumulation the Coal Commission made full use.

Similarly, the appointment, in March, of the Director as a member of the President's Naval Oil Commission was a recognition of the leading part played by the Survey in the geologic and economic study of the oil resources of the country, and especially in the development of the national policy of conservation through leasing publicly owned oil land and setting aside reserves for naval purposes. Again the accumulated information and the trained geologists of the Survey were thus made available, to assist the commission in determining the policy and procedure to be recommended to the President.

Still another item may be mentioned as linking present with past work. In April, 1924, the Survey published a "shorter contribution" by Dr. F. W. Clarke entitled "The evolution and disintegration of matter." More than 50 years ago Doctor Clarke attacked the same subject in a paper on evolution and the spectroscope, and his recent contribution may be regarded as a by-product of this senior chemist's long service in geochemical research-a contribution not unconnected with his service for many years as chairman of the International Committee on Atomic Weights. Further evidence of the value of 
Doctor Clarke's contribution to geologic and chemical science is found in his completion this year of the manuscript for a fifth, revised and enlarged edition of the Data of Geochemistry, which was first published in 1908.

\section{WORK BY THE DIRECTOR}

The Director resumed his administrative duties in the Survey on September 24, immediately after the legal termination of the existence of the Coal Commission, on which he had served. His year's absence had in no wise interrupted nor retarded the progress of the work; indeed, notable advances had been made in the effectiveness of this branch of the public service.

On March 25 the President appointed the Director as one of three members of a commission to study matters pertaining to the naval oil reserves, and on the organization of the commission he was selected to act as chairman. His service on this informal investigating body did not conflict with his regular duties or involve his absence from Washington, except for a visit in May to the naval oil reserves in California and Wyoming.

Late in June the Director attended the first World Power Conference in London as the personal representative of the Secretary of the Interior. At one of the opening general sessions he served as chairman, the subject under discussion being a national review of power resources.

Some of the points of contact between the Survey's scientific and engineering investigations and the public are indicated in the following titles of addresses given by the Director during the year:

October 16, "Lessons from the Coal Commission's work," American Institute of Mining and Metallurgical Engineers, Boston sect:on.

November 20, "The recommendations of the United States Coal Commission," Academy of Political Science, New York.

December 5, "Relations of the Geological Survey to chemical engineer.ng," American Institute of Chemical Engineers, Washington.

December 17, "Engineering outlook on the coal problem," American Institute of Mining and Metallurgical Engineers, Washington section.

December 28, "Fluctuations in mineral output," American Statistical Association, Washington.

January 17, "Coal a national issue," Washington Academy of Science.

February 5, "Foundations of industry," Providence Engineering Society.

February 26, "New England's interest in power," Economic Club, Worcester, Mass.

March 8, "Why superpower?" Economic Club, Portland, Maine.

March 26, "Industrial relations in the coal industry," New Jersey Chamber of Commerce, Newark.

April 1, "Conservation as applied to coal," Lafayette College, Easton, Pa.

April 7, "Coal and law," Federal Law Association, Washington.

May 22, "Planning for power," Massachusetts State Chamber of Commerce, Worcester.

Less formal addresses on the subject of coal were given before the Rotary Club of Skowhegan, Maine; the students at Colby College; the students at Lehigh University; the Women's City Club, Washington; the Thursday Evening Club, Bethlehem, Pa.; the Conservation Society, York, Pa.; the National Industrial Conference Board, New York; and the Delta Kappa Epsilon Association, Washington.

Most of these addresses were printed in technical journals or in proceedings of the societies. 
Supplementing their testimony before the Senate and House committees on agriculture, the Director and Mr. Mansfield prepared an article, "Potash - the key to prosperous agriculture," for publication in the May number of the American Bankers' Association Journal.

\section{PUBLICATIONS}

The publications of the year consisted of 114 books and pamphlets of the regular series, 104 new or revised maps, 203 reprinted maps, and numerous circulars, inquiry forms, lists of publications, etc. The total number of pages in the new book publications was 14,553.

Brief notices of the publications in the regular series and of the new maps are given below.

Forty-Fourth Annual Report of the Director of the United States Geological Survey to the Secretary of the Interior, for the fiscal year ended June 30, 1923. 91 pp., 1 pl. (map).

A tetailed account of the work of the Geological Survey during the year.

Professional Paper 126. Geology of the Coastal Plain of Texas west of Brazos River, by Alexander Deussen. 151 pp., 36 pls. (incl. 2 maps), 38 figs.

Sets forth the results of a geologic investigation of an area of about 38,900 square miles extending from Brazos River southwestward nearly to the Rio Grande.

Frofessional Paper. 131. Shorter contributions to general geology, 1922; David White, chief geologist. 216 pp., 50 pls. (incl. 1 map), 12 figs.

A consofidation of papers published separately in advance. Includes papers on paleontology, stratigraphy, and physiography, covering areas in New England, the Southeastern States, Texas, Colorado, Wyoming, and Ârizona.

I'rofessional Paper 132-A. Rock formations in the Colorado Plateau of southeastern Utah and northern Arizona, by C. R. Longwell, H. D. Miser, R. C. Moore, Kirk Bryan, and Sidney Paige. 25 pp., 10 pls., 1 fig.

Report on the rock formations within the area to be flooded by a proposed storage reservoir to be created by the construction of a large dam on Colorado River at Lees Ferry, Ariz. Covers the geology of the canyons of Colorado and San Juan rivers and the lower parts of tributary canyons.

Professional Paper 132-B. A new fauna from the Colorado group of southern Montana, by J. B. Reeside, jr. 11 pp., 11 pls.

Describes a small but interesting fauna recently collected in the Crow Indian Reservation, Big Horn County.

Professional PaPer 132-C. Notes on the geology of Green River valley between Green River, Wyo., and Green River, Utah, by J. B. Reeside, jr. 18 pp., 6 figs.

Presents notes on geologic features observed during an expedition to gather data needed to complete a study of the power resources of Green River.

Frofessional Paper 132-D. The evolution and disintegration of matter, by F. W. Clarke. $38 \mathrm{pp}, 1$ pl.

The discovery of the "periodic law" led to the conclusion that the so-called chemical elements must have had some community of origin. The suggestion was first published by Doctor Clarke more than 50 years ago that the evolution of planets from nebulae was accompanied by an evolution of the chemical elements. The discovery of radioactivity led to the further discovery that the elements can decay. In the appearance of the so-called "new" stars we probably see a reversion of the evolutiomary process and a return to a nebular condition. In this paper Doctor Clarke summarizes the researches that have led to these conclusions and explains the processes involved.

Professional Paper 132-E. An early Eocene florule from central Texas, by E. W. Berry. 8 pp., 1 pl.

Describes a smanl collection of fossil plants including ten species, obtained near Sayersville, Bastrop County, Tex.

Professionat PAPER 133. The correlation of the Vicksburg group, by C. W. Cooke, and The Foraminifera of the Vicksburg group, by J. A. Cushman. 73 pp., 8 płs., 1 insert.

Mr. Cooke's paper sets forth the results of recent investigations on the Oligocene formations of the Southeastern States and corrects certain errors in the standari correlation tables. Mr. Cushman describes the numerous species of Foraminifera found in the formations of the Vicksburg group and figures many of them. The paper contains a table showing the distribution of the species described. 
Bulletin 689. Boundaries, areas, geographic centers, and altitudes of the United States and the several States, with a bref record of important changes in their territory, by E. M. Douglas. 240 pp., 7 pls. (incl. 4 maps), 22 figs.

A revision of Bulletin 226, published in 1904, with much new matter concerning boundaries and related subjects. Contains a large amount of interesting detailet information on the history of the several boudaries, numerous quotations fron treaties, acts, and other documents, reproductions of ancient maps, and diagrams showing successive changes in boundaries.

Bulletin 709. Triangulation and primary traverse, 1916-1918; С. H. Birdseye, chief topographic engineer. 920 pp., 2 pls. (incl. 1 map).

Gives computed results of the field work of primary control by the Geological Surver. The matter had been published in separate chapters, each covering a State or a group of States.

Bulletin 718. Geology and ore deposits of the Creede district, Colo., by W. H. Emmons and E. S. Larsen. 208 pp., 12 pls. (incl. 3 maps), 32 figs., 1 insert (table of geologic formations).

Ore deposits were discovered near the site of Creede, in Mineral County, Colo.. in 1883 , and the finding of rich ore on several claims in 1891 stimulated a boom that rivaled anything in the earlier history of western mining camps. In the four decades since the first discovery the district has produced over $\$ 40,000,000$ in gold, silver, copper, lead, and zinc. This district is a part of the San Juan Mountains.

Butletry 723. Geology and ore deposits of the Manhattan district, Nev., by H. G. Ferguson. 173 pp., 18 pls. (incl. 5 mars), 15 figs.

Gold was discovered in the Manhattan district in 1905. The greatest production was reached in 1911, and since then mining has declined. This report describes the geology of the district. The author concludes that the lode deposits belong to two periods of metallization-one early Cretaceous and one late Tertiary - and that much of the rich ore mined in the early days of the camp was produced by downward enrichment. Placer gold has been found in the gravel of Manhattan Gulch. The district has probably passed its most productive stage, though many more small ore bodies may still be found.

Burfetrs 735. Contributions to economic geologs (short papers and preliminary reports), 1922, Part I, Metals and nonmetals except fuels; F. $\mathrm{L}$. Ransome, G. R. Mansfield, and E. F. Burchard, geologists in charge. 346 pp., 15 pls. (incl. 4 maps), 67 figs.

The papers in this volume have been published separately, most of them in 1922 The principal subjects considered are silver ores in Nevada, Colorado, and Arizona, iron ores in North Carolina and Tennessee, and peridotite in Arkansas.

BUlletin 736. Contributions to economic geology (short papers and prelimiwary reports), 1922, Part II, Mineral fuels: K. C. Heald, geologist in charge. 260 pp., 24 pls. (incl. 11 maps), 12 figs., 1 insert.

Contains eight papers, previously published in separate form, on oil or gas in Oklahoma, Texas, Montana, Wyoming. and Arkansas.

Litlutrix 739. Mineral resources of Alaska; report on progress of investiga. tions in 1921, by A. H. Brooks and others. 190 pp., 3 pls. (maps), 8 figs.

The eighteenth of a series of annual bulletius summarizing the results of work done by the Geological Survey in Alaska. Contains papers on the Alaska mining industry in 1921, the Wrangell, Cold Bay, Iniskin Bay, and Anchorage districts, and metalliferous deposits in the Yukon and Kuskokwim regions.

Bridstix 744. The lime helt of Massachusetts and parts of eastern New York and western Connecticut, hy T. N. Dale. 77 pp.. 8 pls. (incl. 4 maps), 23 figs.

The lime-producing belt of western Massachusetts and adjacent States contains bot in calcitic and dolomitic limestones, and as each of these varieties bas properties that specially fit it for certain us's a geologic map showing their boundaries is of ceonomic value. This report wives the results of a field study in which these boundaries were traced, describing the areal distribution and characteristic properties of the limestones and the salient features of the quarries that have been opened in them and presenting other pertinent information.

Brimetin 746. Geologic literature on North America, 1785-1918, by J. M. Nickles. Part I, Bibliography, 1169 pp.

Felletin 747. Geologic literature on North America, 1785-1918, by J. M. Nickles. Part II, Index, $660 \mathrm{pp}$.

Bulletin 746 is a cumulation of the series of bibliographies of North American geology issued by the United States Geological Survey as 16 separate bulletins, with the addition of many titles not previously listed. The papers of each author are listed in chronologic order by years, and with each title is given the information needed in finding the paper in a library. Bulletin 747 is an index to the publications listed in Bulletin 746. These books are an essential part of the equipment of every geologist. 
Bulletrin 748. The Twentymile Park district of the Yampa coal field, Routt County, Colo., by M. R. Campbell, 86 pp., 13 pls. (incl. 1 map).

The commercial development of the Yampa coal field was begun in 1906, when the "Moffat railroad" reached its eastern border. Operations have been undertaken in several parts of the field, but there has been a dearth of reliable information as to the correlation of the coal beds and the relative value of the coal mined at different places. This report has been written to supply such information for an important part of the larger field. It describes the geology and gives analyses of the coals and comparisons of their heating value.

Butckerin 749. Geology of the Tullock Creek coal field, Rosebud and Big Horn Counties, Mont., by G. S. Rogers and Wallace I.ee. 187 pp., 16 pls. (incl. 5 maps), 5 figs.

The Tullock Creek coal field includes 900 square miles in the angle formed by the junction of Big Horn River with the Yellowstone, about halfway between Miles City and Billings. It consists of the lands east of the Big Horn ceded to the Government by the Crow Indians in 1904. The coal is subbituminous and compares favorably with the commercial varieties now sold in neighboring markets. This report gives full information concerning the beds considered workable at present. About 20 per cent of the field has been classified as coal land.

Bulletin 750-A. Ilsemannite at Ouray, Utah, by F. L. Hess. 18 pp., 2 pls.. 1 fig.

Describes a water-soluble molybdenum-bearing mineral found in sandstone of Eocene age and gives a brief review of the few known occurrences of ilsemannite elsewhere in the world.

Bulletin 750-B. Origin of certain rich silver ores near Chloride and Kingman, Ariz., by E. S. Bastin. 25 pp., 11 figs.

One of the papers giving the results of Mr. Bastin's general study of silver enrichment in many parts of the Western States. Although some of the richest silver ores of the area, now exhausted. were the products of downward enrichment, the rich ruby silver ores are in the main primary and may be expected to continue to greuter depths than the enriched ores.

Buluetin 751-B. Progress report on a subsurface study of the Pershing oil and gas field, Osage County, Okia., by W. W. Rubey. 52 pp., 3 pls. (incl. 2 maps), 9 figs.

A preliminary statement of the results of an intensive study of the Pershing field, which lies in the east-central part of Osage County a few miles southeast of lawhuska.

Bulletrix 752. Coal resources of the Raton coal field. Colifax County, N. Mex.. by W. T. Lee. 260 pp., 22 pls. (incl. 2 maps), 18 figs.

The Raton coal field is a small part of a great region of coal-bearing rocks in Colorado and New Mexico, which extends about 90 miles from north to south and 50 miles from east to west and includes also the Trinidad coal field of Colorado The coal of this region compares favorably with the best bituminous coai of Ohio and some other fields. Much of it will coke, and at many places it oceurs in thick beds that are easily mined. During the 10 years ending in 1920 this region yielded more than $27,000,000$ tons of coal. The Raton field contains a large quantity of coal in beds of great commercial value, but the geologic conditions are so diverse that careful prospecting is necessary to determine a good location for a mine. This paper gives geologic information concerning the field, paying special attention to genlogic structure, relation of the coal outcrops to slopes, canyons, and other features as bearing on ease of transportation, quality of the coal, and methods of mining.

Bulnetro 754. The Ruby-Kuskokwim region, Alaska, by J. B. Mertie, jr., and G .L. Harrington. 137 pp., 9 pls. ( ncl. 4 maps), 2 figs.

The region described lies in west-central Alaska and includes three of the more productive placer districts of the Yukon Valley-Iditarod, Ruby, and Innoko-also the Candle Creek district. the most productive placer camp in the Kuskokwim Valley. The total valne of the gold and silver produced in these districts to the end of 1922 was over $\$ 27,500,000$. The camps in this region have been describer separately in previous reports, most of which are now either out of stock or out of date. The present volume is a summary report on the whole region and includes much geologle information not previously published.

Buthetin 755-A. The Alaskan mining industry in 1922, by A. H. Brooks and S. R. Capps. 72 pp.

The first chapter of the nineteenth annual bulletin on the mineral resources of Alaska. Shows that the value of the total mineral production in 1922 was $\$ 2,500,000$ greater than in 1921. Expresses the conviction that in spite of rather widespread pessimism the Alaskan mining industry is now on a more substantial basis than ever. before and is advancing, not retrograding. Gives statistics covering several years for all the principal mining districts and contains a list of recent Survey publications on Alaska.

Butuetin 755-B. The metalliferous deposits of Chitina Valley, Alaska, by F. H. Moffit. $18 \mathrm{pp}$.

Summarizes the mode of occurrence of the valuable minerals so far discovered in Chitina Valley and points out their relation to the geologic formations and strueture. Copner is the chief metal mined commercially, but gold and silver have also been produced. 
Fulletin 755-C. Geology and mineral resources of the region traversed by the Alaska Railroad, by S. R. Capps. 82 pp., 7 pls., 1 fig.

The Government railroad between Seward and Fairbanks, Alaska, completed in March, 1923, has profoundly affected the welfare of a large region, providing, for example, a comfortable journey of a few hours in place of weeks of severe physical exertion over a trailless country. The effects of the stimulus of better transportation are already evident, but the railroad has been in operation too short a time to do more than start the intensive development of the country, and the population now served by the railroad is no index of the number of people this region may some time support. In the development that is to come an inventory of the resources of the region will be of great assistance, and this bulletin supplies such information for the mineral industry. The railroad also provides an easy summer tourist trip that includes a great variety of scenery, and the notes on the geography of the region given in this bulletin will be of interest to the prospective traveler.

Bumetin 760-A. Pedestal rocks in the arid Southwest, by Kirk Bryan. 13 pp., 5 pls.

One of the "Contributions to the geography of the United States.", Considers the causes that produce the peculiar forms sometimes called "hoodoos" or " mushrooms," and concludes from a study of some of these rocks in Arizona and New Mexico that even in an arid regicn water erosion as well as wind scour may contribute to their formation.

WATER-Supply PAPER 489. The occurrence of ground water in the United States, with a discussion of principles, by 0 . E. Meinzer. 333 pp., 31 pls. (incl. 5 maps), 110 figs.

The first of a series of papers on the general subject of ground water in the United States. Discusses principles of occurrence, kinds of rocks and their waterbearing properties, structure of rocks and its influence on ground water, and waterbearing formations in the United States. The paper is abundantly illustrated by diagrams and photographic views.

WATER-SUPPLY PAPER 492. Summary of hydrometric data in Washington, 1878-1919, by G. L. Parker and Lasley Lee. 371 pp., 9 pls. (incl. 1 map).

Records of stream flow in Washington were first collected by the United States Geological Survey in 1893, and from that time to September 30,1919 , records have been made at 209 gaging stations. The details of these records, which are given in 45 different volumes published by the Survey, are summarized in this paper in convenient form. Data based on earlier records showing the discharge of lower Columbia River since 1878 and Spokane River since 1891 are also given. The paper contains a bibliography.

WATER-Supply PAPER 494. Outline of ground-water hydrology, with definitions by 0 . E. Meinzer. 75 pp., 35 figs.

This paper gives the results of an attempt to find the concepts involved in the seience of ground-water hydrology, to ascertain their relations to one another, to state accurately what these concepts are, and to find terms for the concepts defined.

Th ATER-Supply PAPER 497. The Salton Sea region, Calf., a geographic, geologic, and hydrologic reconnaissance, with a guide to desert watering places, by J. S. Brown. 308 pp., 19 pls. (incl. 4 maps), 18 figs.

One of the final reports on the desert watering place survey authorized by Congress in 1917. The places in this region at which water can be had are widely separated oases in a vast territory that must always remain essentially a desert, though it contains prosperous cities, fertile agricultural districts, and rich mines. The information given is of prime value to travelers. The present volume covers an area of 10,000 square miles in southeastern California that includes the Salton Sea, which lies far below sea level and has had a unique geologic history; the famous Imperial Valley, one of the largest irrigation districts in the country; and the Government experimental date gardens, which promise to establish a permanent industry.

WATEn-SUPPLy PAPER 498. The lower Gila region, Ariz., a geographic, geologic, and hydrologic reconnaissance, with a guide to desert watering places, by C. P. Ross. 251 pp., 23 pls. (incl. 5 maps), 16 figs.

Another of the final reports on the survey of desert watering places authorized by Congress in 1917. Four preliminary guidebooks have been issued covering areas amounting to 60,000 square miles in southeastern California and southwestern Arizona, and the present paper is one of four detailed reports on the same areas. Besides specific information in regard to watering places and routes of travel, it gives general information in regard to the geography, geology, and hydrology of the region, some of it compiled from existing publications, but a large part of it new. The lower Gila region is mainly in Yuma and Maricopa counties, Ariz., north of Gila River and east of Colorado River. Among the illustrations in this report are three large-scale relief maps.

W Ater-Supply Paper 501. Surface water supply of the United States, 1919-20, Part I, North Atlantic slope drainage basins; N. C. Grover, chief hydraulic engineer; C. H. Pierce, C. C. Covert, O. W. Hartwell, and G. C. Sterens, district engineers. 330 pp., 2 pls. 
WATER-SUPPLY PAPER 502. Surface water supply of the United States, 1919 and 1920, Part II, South Atlantic slope and eastern Gulf of Mexico basins: N. C. Grover, chief hydraulic engineer; G. C. Stevens, C. G. Paulsen, and W. E. Hall, district engineers. 84 pp., 2 pls.

Water-Supply Paper 503. Surface water supply of the United States, 1919 and 1920, Part III, Ohio River basin; N. C. Grover, chief hydraulic engineer ; O. W. Hartwell, G. C. Stevens, W. E. Hall, W. R. King, and C. G. Paulsen, district engineers. 263 pp., 2 pls.

Water-Supply PAPre 505. Surface water supply of the United States, 1919 and 1920, Part V, Hudson Bay and upper Mississippi River basins ; N. C. Grover, chief hydraulic engineer; W. A. Lamb and W. G. Hoyt, district engineers. 293 pp., 2 pls.

Water-Supply Paper 506. Surface water supply of the United States, 1919 and: 1920, Part VI, Missouri River basin; N. C. Grover, chief hydraulic engineer; W. A. Lamb, Robert Follansbee, W. G. Hoyt, and R. C. Rice, district engineers. 411 pp., 2 pls.

Water-Supply Paper 510. Surface water supply of the United States, 1919 and: 1920, Part X, The Great Basin; N. C. Grover, chief hydraulic engineer;: A. B. Purton, H. D. MeGlashan, F. F. Henshaw, C. G. Paulsen, and Robert Follansbee, district engineers. 354 pp., 2 pls.

Water-Supply Paper 511. Surface water supply of the United States, 1919 and 1920, Part XI, Pacific slope basins in California ; N. C. Grover, chief hydraulic engineer; H. D. McGlashan and F. F. Henshaw, district engineers. 464 pp., 2 pls.

WATER-Supply PAPER 512. Surface water supply of the United States, 1919 and 1920, Part XII, North Pacific slope drainage basins, A, Pacific basins in Washington and upper Columbia River basin; N. C. Grover, chief hydraulic. engineer; G. L. Parker and IV. A. Lamb, district engineers. 268 pp., 2 pls.

Eight papers of a series giving results of stream gaging during the years ended September 30,1919 and 1920 .

Water-Supply Paper 515. Surface whter supply of Hawaii, July 1, 1918. to June 30, 1919; N. C. Grover, chief hydraulic engineer; C. T. Bailey and: J. E. Stewart, acting district engineers. 127 pp.

The regular report on stream gaging.

WATER-SUPPly PAPER 520-A. Variation in annual run-off in the Rocky Mountain region, by Robert Follansbee. 16 pp., 2 pls., 2 figs.

Gives the results of a study of records of stream flow at 20 gaging stations on 19 rivers in the Rocky Mountain region for periods ranging from 14 to 38 years.

Water-Supply PAPER 520-B. Additional ground-water supplies for the city of Enid, Okla., by B. C. Renick. 14 pp., 3 figs.

Report of an investigation made at the request of the city of Enid to obtain information bearing on a proposed increase in the city water supply. Concludes that at relatively small cost the present supply can be increased to yield 110 gallons a day per capita for 30,000 people.

WATER-StPPIY PAPER 524. Surface water supply of the United States, 1921, Part IV, St. Lawrence River hasin; N. C. Grover, chief hydraulic engineer : S. B. Soulé, A. H. Horton, C. C. Covert, and C. H. Pierce, district engi-neers. 116 pp.. 2 pls.

WATER-Supply PAPER 527. Surface water supply of the United States. 1921, Part VII, Lower Mississippi River basin; N. C. Grover, chief hydraulic engineer; Robert Follansbee and E. L. Williams, district engineers. $43 \mathrm{pp}$. . 2 pls.

WATER-SUPPLY PAPER 528. Surface water supply of the United States. 1921. Part VIII, Western Gulf of Mexico basins; N. C. Grover, chief hydraulic engineer ; C. E. Ellsworth, district engineer. 100 pp., 2 pls.

Three reports giving results of stream gaging in the basins indicated during the year ended Sept. 30, 1921.

Mineral Resources of The United States, 1920; G. F. Loughlin, geologist in charge, division of mineral resources. Part I, Metals, 766 pp. 2 pls., 17 figs.

A consolidation of reports on the different metals published separately between May, 1921, and July, 1922, with a summary covering both metals and nonmetals. 
Mineral Resources of the United States, 1920; G. F. Loughlin, geologist in charge, division of mineral resources. Part II, Nonmetals, 533 pp., 2 pls., 25 figs., 1 insert.

A consolidation of chapters published at intervals between July, 1921, and December, 1922.

Mixeral Resources of the United States, 1921; G. F. Loughlin, geologist in charge, division of mineral resources. Part I, Metals, 751 pp., 1 pl., 14 figs.

Mineral Resources of the United States, 1921; G. F. Loughlin, geologist in charge, division of mineral resources. Part II, Nonmetals, 688 pp., 1 pl., 53 figs., 1 insert.

These books consist of a consolidation of more than 60 separate chapters, which were issued at different dates between April, 1922, and October, 1923 (one chapter issued during the year). The grand total value of all mineral products for the year was about $\$ 4,138,670,000$, a decrease of 41 per cent from the total for 1920 .

Mineral Resources of the United States, 1922. 57 advance chapters.

Mineral Resources of the United States, 1923. 1 advance chapter.

Geologic Folio 215. Hot Springs, Ark., by A. H. Purdue and H. D. Miser. 12 folio pages of text, 2 maps, 1 columnar-section sheet, 1 structure-section sheet, 8 pls., 8 figs.

The area described as the Hot Springs district covers about 245 square miles around the city of Hot Springs, Ark., mostly in Garland County. It lies in the eastern part of the Ouachita Mountain region, a mountainous province that extends from Atoka, okla., to Little Rock, Ark. This folio sets forth the general geography and geology of this province as an introduction to the more detailed presentation of the geology of the Hot Springs district. The district is known principally for the famous hot springs from which its only city is named. These springs and the mountains adjacent to them are under the control of the Government as a national park. The origin of the hot springs is discussed at length. The principal mineral resources of the district are rock suitable for making oilstones, road material, clay, and shale.

Gelologic Folio 216. Carlyle-Centralia, Ill., by E. W. Shaw. 10 folio pages of text, 4 maps, 5 figs.

Describes an area of 466 square miles in southwestern Illinois, lying in the Till Plains section of the Central Lowland province, a region that consists chiefly of glaciated plains and lies between the Appalachian Highlands and the Great Plains. A general description of the geography and geology of this province is given as an introduction to the detailed description of the two quadrangles. The bedrocks are exposed at few places in this area, being almost everywhere buried under beds of loess, glacial till, and alluvium, but information concerning them is afforded by records of borings made for oil and coal. The section on geologic history includes a detailed account of the glaciation of this area. Its ehief economic mineral resources are coal, oil, and gas.

Geologic Folio 217. Ray, Ariz., by F. L. Ransome. 24 fol o pages of text, 4 maps, 8 pls., 13 figs.

Describes the geology of an area of 250 square miles in Glla and Pinal counties, Ariz., in which the principal industries are the mining, milling. and smelting of copper ore. Ray and a few other settlements contain a total population of about 10,000 , but much of the area is a wilderness. The geologic formations exposed in this area range in age from pre-Cambrian to Cretaceous, and the geologic history is: a record of sedimentation, deformation, intrusion, metamorphism, eruption, uplift, and erosion. The copper deposits are the chief resources of the area, but it contains also ores that yield gold, silver, lead, zinc, and vanadium.

Geologic Folio 218. Riddle, Oreg., by .J. S. Diller and G. F. Kay. 8 folio pages of text, 3 maps, 8 figs.

The Riddle quadrangle covers an area of 910 square miles in southwestern Oregon, between the Cascade Range on the east and the Coast Ranges and Klamath Moun tains on the west. The population is about 5,000 and the chief industries are lumbering and mining. The geologic formations include both sedimentary and igneous rocks and are of Paleozoic and later age. These formations record re peated uplift and mountain building, subsidence and sedimentation, erosion, and volcanism. The mineral resources are gold, nickel, and copper. This folio describes the geology of the quadrangle and of the larger region of which it forms a part.

TOPOGRAPHIC AND OTHER MAPS as follows. The maps marked with an asterisk (*) were published also with green overprint showing woodland.

\section{Alabama}

State of Alabama. Scale, 1 inch $=8$ miles.

Base map of the State of Alabama, printed in black. Shows county boundaries, location and names of all towns and most of the smaller settlements, railroads, rivers, and many of the smaller streams and water features. This map does not show contours. 
Alaska

Alaska (relief map). Scale, 1 inch=391/2 miles; no contour lines.

Shaded relief map in which the physical features are brought out by an overprint in shades of brown, on the conventional plan of assumed illumination from the northwest. The water features are shown in blue, and the glaciers are shown by a blue overprint in a conventional pattern. 'The shading brings out well the trend of the chief mountain ranges and the difference in height between the ranges of southern Alaska and those of the central and northern parts of the Territory, as well as the contrast in relief between the mountain ranges and the coastal plains, interior basins, and Arctic slope. The contrast of the brown-tinted land and the blue-tinted ocean emphasizes the raggedness of the coast of southeastern and southwestern Alaska and the comparative smoothness of the coast of western and northern Alaska. The map shows that the glaciers are confined to the higher mountains of the south and southeast and illustrates the fact that the existence of glaciers is more dependent on altitude and precipitation than on latitude alone.

Alaska Railroad-Seward to Matanuska coal field: Latitude, $59^{\circ} 40^{\prime}$ to $61^{\circ} 55^{\prime}$; longitude, $147^{\circ}$ to $151^{\circ}$. Scale, 1 inch $=4$ miles; contour interval, 200 feet.

Topographic map of the region adjacent to the southern third of the Alaska Railroad, including the country between Prince William Sound on the east and the head of Cook Inlet on the west, and extending from the Pacific Ocean at Seward northward to the Talkeetna Range. Considerable portions of the coast line and the adjacent country have been mapped in detail, as well as a belt of territory several miles wide along the line of the railroad, but the remainder of the region is only imperfectly known, and the features of some areas in it are represented only by blank spaces. Among the striking features shown are the deep fiords of the northwest coast of Prince William Sound, the huge glaciers among the mountains back of that coast, and the great depression which separates the Kenai Mountains on the south from the Chugach Mountains on the north, and through which the waters of Prince William Sound and Cook Inlet almost meet.

\section{Arizona}

State of Arizona. Scale, 1 inch $=8$ miles.

Base map of the State of Arizona, printed in two colors. Shows county boundaries, location and names of all towns and most of the smaller settlements, and railroads (in black) and rivers and many of the smaller streams and water features (in blue). This map does not show contours.

\section{California}

Bullard: Latitude, $36^{\circ} 45^{\prime}$ to $36^{\circ} 52^{\prime} 30^{\prime \prime}$; longitude, $119^{\circ} 45^{\prime}$ to $119^{\circ} 52^{\prime} 30^{\prime \prime}$. Scale, 1 inch $=1 / 2$ mile; contour interval, 5 feet.

Map of an area in Fresno and Madera counties at the northeast side of San Joaquin Valley, just south of the place where San Joaquin River emerges from the foothills of the Sierra. The area is crossed by several low southwestward trending alluvial ridges built by distributaries of the river at times of flood, which are now traversed by irrigation ditches that bring water from the foothills. San Joaquin River crosses the northwestern part of the area. Part of the city Fresno is included in the southern part of the area.

Citrus Cove: Latitude, $36^{\circ} 37^{\prime} 30^{\prime \prime}$ to $36^{\circ} 45^{\prime}$; longitude, $119^{\circ} 15^{\prime}$ to $119^{\circ} 22^{\prime}$ $30^{\prime \prime}$. Scale, 1 inch $=1 / 2$ mile; contour interval, 5 feet.

Map of parts of Fresno and Tulare counties, in the eastern part of San Joaquin Valley, at the base of the foothills of the Sierra Nevada.

Clovis: Latitude, $36^{\circ} 45^{\prime}$ to $36^{\circ} 52^{\prime} 30^{\prime \prime}$; longitude, $119^{\circ} 37^{\prime} 30^{\prime \prime}$ to $119^{\circ} 45^{\prime}$. Scale, 1 inch $=1 / 2$ mile; contour interval, 5 feet.

Map of an area in Fresno County, in the eastern part of San Joaquin Valley

Conejo: Latitude, $36^{\circ} 30^{\prime}$ to $36^{\circ} 37^{\prime} 30^{\prime \prime}$; longitude, $119^{\circ} 37^{\prime} 30^{\prime \prime}$ to $119^{\circ} 45^{\prime}$. Scale, 1 inch $=1 / 2$ mile; contour interval, 5 feet.

Map of part of Fresno County, in San Joaquin Valley, whose surface is crossea by an irregular line of depressions, 15 to 20 feet deep, which probably mark the course of a former distributary of Kings River. Many of the deeper depressions contain ponds, some of them intermittent. The area contains no permanent streams but is crossed by irrigation ditches that reach all parts of it.

Englebrecht Ranch : Latitude, $36^{\circ} 30^{\prime}$ to $36^{\circ} 37^{\prime} 30^{\prime \prime}$; longitude, $120^{\circ} 15^{\prime}$ to $120^{\circ} 22^{\prime} 30^{\prime \prime}$. Scale, 1 inch $=1 / 2$ mile; contour interval, 5 feet.

Map of an area in Fresno County, in the southwestern part of San Joaquin Valley. It contains no permanent streams and is inhabited only in a part of its northeast corner, which is irrigated by ditches.

Gravelly Ford: Latitude, $36^{\circ} 45^{\prime}$ to $36^{\circ} 52^{\prime} 30^{\prime \prime}$; longitude, $120^{\circ} 7^{\prime} 30^{\prime \prime}$ to $120^{\circ} 15^{\prime}$. Scale, 1 inch $=1 / 2$ mile; contour interval, 5 feet.

Map of an area in Madera and Fresno counties, on the alluvial plain of San Joaquin River. Across this plain the river flows in a channel 5 to 10 feet in depth. 
Herndon: Latitude, $36^{\circ} 45^{\prime}$ to $36^{\circ} 52^{\prime} 30^{\prime \prime}$; longitude, $119^{\circ} 52^{\prime} 30^{\prime \prime}$ to $120^{\circ}$. Scale, 1 inch $=1 / 2$ mile; contour interval, 5 feet.

Map of an area in Fresno and Madera counties, in San Joaquin Valley a little east of the great bend of San Joaquin River, which crosses the northern part of the area, swinging from side to side of a slightly sinuous trench half a mile wide and 50 feet deep.

Laguna Seca Ranch: Latitude, $36^{\circ} 45^{\prime}$ to $36^{\circ} 52^{\prime} 30^{\prime \prime}$; longitude, $120^{\circ} 45^{\prime}$ to $120^{\circ} 52^{\prime} 30^{\prime \prime}$. Scale, 1 inch $=1 / 2$ mile; contour interval, 5 and 25 feet.

Map of an area in Fresno and Merced counties, on the west side of San Joaquin Valley, at the northeast base of the Panoche Hills.

Levis: Latitude, $36^{\circ} 30^{\prime}$ to $36^{\circ} 37^{\prime} 30^{\prime \prime}$; longitude, $120^{\circ} 22^{\prime} 30^{\prime \prime}$ to $120^{\circ} 30^{\prime}$. Scale, 1 inch=1/2 mile; contour interval, 5 and 25 feet.

Map of an area in Fresno County, in the western part of San Joaquin Valley, at the northeast base of Monocline Ridge. The southwest corner is occupied by a part of Monocline Ridge, one peak of which stands 1,150 feet above sea level.

Malaga: Latitude, $36^{\circ} 37^{\prime} 30^{\prime \prime}$ to $36^{\circ} 45^{\prime}$; longitude, $119^{\circ} 37^{\prime} 30^{\prime \prime}$ to $119^{\circ} 45^{\prime}$. Scale, 1 inch $=1 / 2$ mile; contour interval, 5 feet.

Map of an area in Fresno County, in the eastern part of San Joaquin Valley, including in its northwest corner part of the city of Fresno.

Mendota : Latitude, $36^{\circ} 45^{\prime}$ to $36^{\circ} 52^{\prime} 30^{\prime \prime}$; longitude, $120^{\circ} 15^{\prime}$ to $120^{\circ} 22^{\prime} 30^{\prime \prime}$. Scale, 1 inch $=1 / 2$ mile; contour interval, 5 feet.

Map of parts of Madera and Fresno counties, in San Joaquin Valley, at the junction of San Joaquin River and Kings River Slough.

Monocline Ridge: Latitude, $36^{\circ} 30^{\prime}$ to $36^{\circ} 37^{\prime} 30^{\prime \prime}$; longitude, $120^{\circ} 30^{\prime}$ to $120^{\circ}$ $37^{\prime} 30^{\prime \prime}$. Scale, 1 inch $=1 / 2$ mile; contour interval, 5 and 25 feet.

Map of an area in Fresno Ccunty, in the western part of San Joaquin Valley, at the northeast base of Monocline Ridge.

Orangedale School : Latitude, $36^{\circ} 45^{\prime}$ to $36^{\circ} 52^{\prime} 30^{\prime \prime}$; longitude, $119^{\circ}, 22^{\prime} 30^{\prime \prime}$ to $119^{\circ} 30^{\prime}$. Scale, 1 inch $=1 / 2$ mile; contour interval, 5 feet.

Map of an area in Fresno County, in the valley of Kings River, where it emerges from the foothills of the Sierra Nevada. Kings River emerges from its gorge at an elevation of 500 feet as a braided stream and is tapped by irrigation canals' at several places in the next few miles. The floor of the valley widens from one-fourth of a mile at the mouth of the gorge to more than a mile at the south margin.

Reedley: Latitude, $36^{\circ} 30^{\prime}$ to $36^{\circ} 37^{\prime} 30^{\prime \prime}$; longitude, $119^{\circ} 22^{\prime} 30^{\prime \prime}$ to $119^{\circ} 30^{\prime}$. Scale, 1 inch $=1 / 2$ mile; contour interval, 5 feet.

Map of parts of Tulare and Fresno counties, in the eastern part of San Joaquin Valley. Kings River flows southward across the western part of the area between banks 20 to 50 feet high, and an abandoned channel about 20 feet deep lies' west of the present one.

Selma : Latitude, $36^{\circ} 30^{\prime}$ to $36^{\circ} 37^{\prime} 30^{\prime \prime}$; longitude, $119^{\circ} 30^{\prime}$ to $119^{\circ} 37^{\prime} 30^{\prime \prime}$. Scale, 1 inch $=1 / 2$ mile; contour interval, 5 feet.

Map of a part of Tulare and Fresno counties, in San Joaquin Valley. Kings River, the principal stream of the region, crosses the southeast corner of the area. and its water, which is taken from the river farther up and carried in ditches or canals, is used to irrigate the entire area. A first-class automobile road crosses the area through the towns of Kingsbury and Selma.

Stokes Mountain: Latitude, $36^{\circ} 30^{\prime}$ to $36^{\circ} 37^{\prime} 30^{\prime \prime}$; longitude, $119^{\circ} 7^{\prime} 30^{\prime \prime}$ to $119^{\circ} 15^{\prime}$. Scale, 1 inch $=1 / 2$ mile; contour interval, 5 feet.

Map of part of Tulare County, along the foothills on the east side of San Joaquin Valley. Only the part of the area lying below 600 feet above sea level has been mapped.

Sultana : Latitude, $36^{\circ} 30^{\prime}$ to $36^{\circ} 37^{\prime} 30^{\prime \prime}$; longitude, $119^{\circ} 15^{\prime}$ to $119^{\circ} 22^{\prime} 30^{\prime \prime}$. Scale, 1 inch=1/2 mile; contour interval, 5 and 25 feet.

Map of an area in Fresno and Tulare counties, in the northeastern part of San Joaquin Valley. The area is crossed by the shallow furrows of a few intermittent streams. Two mountains-Smith Mountain and Curtis Mountain-rise boldly above the plain to heights of 1,019 and 1,310 feet, respectively.

Tierra Loma School : Latitude, $36^{\circ} 37^{\prime} 30^{\prime \prime}$ to $36^{\circ} 45^{\prime}$; longitude, $120^{\circ} 37^{\prime} 30^{\prime \prime}$ to $120^{\circ} 45^{\prime}$. Scale, 1 inch $=1 / 2$ mile; contour interval, 5 feet and 25 feet.

Map of an area in Fresno County, in the southwestern part of San Joaquin Valley, at the base of the Panoche Hills.

Torrance: Latitude, $33^{\circ} 48^{\prime}$ to $33^{\circ} 54^{\prime}$; longitude, $118^{\circ} 18^{\prime}$ to $118^{\circ} 26^{\prime}$. Scale, 1 inch $=2,000$ feet ; contour interval, 5 feet.

Map of part of Los Angeles County, in southern California, on the coast just north of the San Pedro Hills, whose northern base enters the southern part of the area mapped. Off Redondo Beach the under-water contours reveal a deep channel. which leads out from the shore and descends sharply to a depth of more than 800 feet below sea level.

$11580-24-2$ 
Tumey Hills : Latitude, $36^{\circ} 32^{\prime} 30^{\prime \prime}$ to $36^{\circ} 37^{\prime} 30^{\prime \prime}$; longitude, $120^{\circ} 37^{\prime} 30^{\prime \prime}$ to $120^{\circ} 45^{\prime}$. Scale, 1 inch $=1 / 2$ mile; contour interval, 5 and 25 feet.

Map of part of an area in Fresno and San Benito counties, among the foothills on the southwest side of San Joaquin Valley. The area is crossed by the gulches of Panoche and Silver creeks, which are several hundred feet deep.

Wahtoke: Latitude, $36^{\circ} 37^{\prime} 30^{\prime \prime}$ to $36^{\circ} 45^{\prime}$; longitude, $119^{\circ} 22^{\prime} 30^{\prime \prime}$ to $119^{\circ} 30^{\prime}$. Scale, 1 inch $=1 / 2$ mile; contour interval, 5 and 25 feet.

Map of part of Fresno County on the east side of San Joaquin Valley, where Kings River emerges from the foothills of the Sierra Nevada. Kings River flows southward across the western part of the area in several shallow interlaced channels on a broad flood plain bounded by banks 25 to 30 feet high.

Wisdom Well : Latitude, $36^{\circ} 45^{\prime}$ to $36^{\circ} 52^{\prime} 30^{\prime \prime}$; longitude, $120^{\circ} 30^{\prime}$ to $120^{\circ}$ $37^{\prime} 30^{\prime \prime}$. Scale, 1 inch $=1 / 2$ mile; contour interval, 5 feet.

Map of part of Fresno County, in the western part of San Joaquin Valley. There are no permanent streams in the area, which is elmost uninhabited, excent a small part at its eastern margin, which is irrigated from deep wells.

\section{Hawaii}

* Honuapo: Latitude, $19^{\circ}$ to $19^{\circ} 15^{\prime}$; longitude, $155^{\circ} 30^{\prime}$ to $155^{\circ} 45^{\prime}$ Scale 1 inch $=1$ mile; contour interval, 50 feet.

Map of part of the southeastern side of the island of Hawaii, extending from sea level in the southeastern part of the area to 7,350 feet in the northwest corner on the slope of Mauna Loa. The outlines of extensive recent lava flows are indicated and the character of the lava, whether aa or pahoehoe, is shown by a convention of the contouring. Parasitic cones, fault scarps, and earthquake cracks are also indicated.

* Kalae: Latitude, $18^{\circ} 45^{\prime}$ to $19^{\circ}$; longitude, $155^{\circ} 35^{\prime}$ to $155^{\circ} 50^{\prime}$. Scale, 1 inch $=1$ mile; contour interval, 50 feet.

Map of part of the southern angle of the island of Hawaii, which ranges in altitude from sea level along the shore to 1,150 feet at Puu Kauwila, near the northern margin. A great fault scarp extends from the shore northward beyond the area. The outlines of extensive recent lava flows are indicated, and the two kinds of lava, a and pahoehoe, are shown by a convention of the contouring.

"Pahala: Latitude, $19^{\circ}$ to $19^{\circ} 15^{\prime}$; longitude, $155^{\circ} 15^{\prime}$ to $155^{\circ} 30^{\prime}$. Scale 1 inch $=1$ mile; contour interval, 50 feet.

Map of part of the Kau district, on the southeastern coast of the island of Hawaii, on the southern slope of the great volcano of Mauna Loa. The surface of the area rises from sea level to 2,700 feet in the northwest corner. The outlines of several recent lava flows are inclicated, as well as a number of large cracks and a few parasitic cones, and the difference in the character of the surface of the two sorts of lava, a and pahoehoe, is shown by a convention of the contouring.

\section{Idaho-Oregon}

Snake River. Plan and profile of Snake River, Lewiston, Idaho, to Huntington, Oreg. Scale, 1 inch=1/2 mile; contour interval, on land, 25 feet, on river surface, 5 feet; vertical scale of profiles, 1 inch $=20$ feet. Size, 20 by 19 inches (except sheet $\mathrm{I}$, which is 23 by 19 inches). 17 sheets (10 plans, 7 profiles).

Sheets A to $\mathrm{H}$ show the course of Snake River from the mouth of Burnt River, near Huntington, Oreg., to the mouth of Clearwater River, at Lewiston, Idaho. All rapids and islands in the stream and the sand flats along its course are shown, and the form of the immediately adjacent slopes is shown by contours. Sheet I is a map of the part of the Nez Perce National Forest that lies between Snake and Salmon rivers. Sheet J shows the topography of several proposed dam sites, on the scale of 1 inch to 400 feet and with 10 -foot contours. Sheets $K$ to $Q$ show the profile of Snake River throughout the stretch mapped.

\section{Illinois}

*Buda: Latitude, $41^{\circ} 15^{\prime}$ to $41^{\circ} 30^{\prime}$; longitude, $89^{\circ} 30^{\prime}$ to $89^{\circ} 45^{\prime}$. Scale, 1 inch $=1$ mile; contour interval, 20 feet.

Map of an area in Bureau County, in the Glacial Till Plains. The most prominent features of the relief are several broad, irregular morainal ridges 50 to 200 feet high. The Illinois and Mississippi Canal crosses the area from east to west through a low gap in the moraine.

*Dongola : Latitude, $37^{\circ} 15^{\prime}$ to $37^{\circ} 30^{\prime}$; longitude, $89^{\circ}$ to $89^{\circ} 15^{\prime}$. Scale, 1 inch $=1$ mile; contour interval, 20 feet.

Map of parts of Union, Pulaski, Johnson, and Alexander counties, in the southern end of the State. An old abandoned river valley, 3 to 4 miles wide, crosses the southern part of the area and is traversed by Cache River in a marsh-bordered course, which is remarkably straight, as conpared with the meandering courses of the other streams. The southern margin of the area lies in the Mississippi embayment portion of the Gulf Coastal Plain. 
*Monmouth: Latitude, $40^{\circ} 45^{\prime}$ to $41^{\circ}$; longitude, $90^{\circ} 30^{\prime}$ to $90^{\circ} 45^{\prime}$. Scale, 1 inch $=1$ mile; contour interval, 20 feet.

Map of part of Warren County, in the Till Plains. The nearly flat surface of the area lies 700 to 785 feet above sea level and is cut to a depth of 20 to 60 feet by the steep-sided valleys of several creeks and by the ravines of numerous small tributaries.

\section{Illinois-Missouri}

Jonesboro: Latitude, $37^{\circ} 15^{\prime}$ to $37^{\circ} 30^{\prime}$; longitude, $89^{\circ} 15^{\prime}$ to $89^{\circ} 30^{\prime}$. Scale, 1 inch=1 mile; contour interval, 20 feet. (New edition, showing entire quadrangle; previous edition showed only the portion in Illinois.)

Map of parts of Union and Alexander counties, Ill., and Cape Girardeau County, Mo., in the extreme southeast corker of the Ozark upland. The summit of Atwood Ridge rises 900 feet above sea level. Mississippi River flows southward across the western part of the area in a trench 3 to 4 miles wide and nearly 300 . feet deep.

\section{Illinois-Wisconsin}

\section{[See also Wisconsin-Illinois]}

*Grays Lake: Latitude, $42^{\circ} 15^{\prime}$ to $42^{\circ} 30^{\prime}$; longitude, $88^{\circ}$ to $88^{\circ} 15^{\prime}$. Scale, 1 inch $=1$ mile; contour interval, 10 feet.

Map of parts of Lake and McHenry counties, Ill., and Kenosha County, Wis., in the Eastern Lake section. The terminal moraine of the Lake Michigan lobe of the' Wisconsin ice sheet traverses the western part of the area, where some knolls and short ridges stand 100 feet above the general level. Many of the hollows: throughout the area are occupied by swamips and small ponds, and Fox River flows southward across its western part through a chain of lakes of irregular form, most of which have marshy shores.

\section{Kentucky}

*Bowling Green: Latitude, $36^{\circ} 45^{\prime}$ to $37^{\circ}$; longitude, $86^{\circ} 15^{\prime}$ to $86^{\circ} 30^{\prime}$. Scale; 1 inch=1 mile; contour interval, 20 feet.

Map of parts of Warren, Allen, and Simpson counties, in a relatively low part of the Highland Rim Plateau. The northwestern half of the area is a gently rolling plain, which stands 500 to 600 feet above sea level and which, especially in its eastern part, is pitted with hundreds of sinkholes and larger irregular depressions. Nearly all the drainage ways except the large streams ard underground. The southeastern half of the area is an upland, whose rather irregular surface, much cut by ravines, lies 600 to 800 feet above sea level and is drained ehíefly by surface streams. Barren River and several branches of Drakes Creek cross the area in meandering trenches cut 100 feet or more below the level.

* Mammoth Cave: Latitude, $37^{\circ}$ to $37^{\circ} 15^{\prime}$; longitude, $86^{\circ}$ to $86^{\circ} 15^{r}$. Scale, 1 inch $=1$ mile; contour interval, 20 feet.

Map of parts of Edmonson, Barren, Warren, and Hart counties, near the northwestern margin of the Highland Rim Plateau. The upland surface is cut by the winding trenches of Green and Nolin rivers. The conspicuous featwres of the area are the absence of surface drainage in a large part of it and the hundreds of sink holes. Mammoth Care is in a ridge in the northeast-central part of the area, among the largest and deepest sinks.

State of Kentucky (relief map). Scale, 1 inch $=8$ miles; no contour lines.

Shaded relief map in which the physical features are brought out by an overprint in shades of brown, on the conventional plan of assumed illumination from the northwest. The water features are shown in blue. The shading brings out strongly the hilly character of the two coal fields of the State, particularly the eastern field, in which the topography is very rugged. A belt of hills surrounds the bluegrass region of Lexington and Frankfort, accentuating the level character of this region, which is broken only by the deep gorges of Kentucky and Licking rivers. The Jackson Purchase region, west of Tennessee River, is the lowest part of the State. The only mountainous topography is in the southeast corner of the State, where Pine and Cumberland monntains, typical Appalachian ridges, enter the State from the south.

\section{Maine}

* Farmington: Latitude, $44^{\circ} 30^{\prime}$ to $44^{\circ} 45^{\prime}$; long tude, $70^{\circ}$ to $70^{\circ} 15^{\prime}$. Scale, 1 inch $=1$ mile ; contour interval, 20 feet.

Map of part of Franklin. Kennebec, and Somerset counties, just off the southeastern border of the mountainous part of the State. More than half the area is forested, the cultivated land being limited to that which is most easily accessible. Sandy River, a tributary of the Kennebec, drains all of the area except the southwest corner, which is crossed by Androscoggin River. The map shows a secondary automobile highway across the area from south to north, passing through the town of Jay, Wilton, Farmington, and Fairbanks. South of Chesterville, for a distance of 4 miles, a road occupies the crest of a narrow ridge which in places is 50 feet high. Such ridges, known as eskers, were formed under a great ice sheet that once covered all this region. 


\section{Michigan}

* Marshall: Latitude, $42^{\circ} 15^{\prime}$ to $42^{\circ} 30^{\prime}$; longitude, $84^{\circ} 45^{\prime}$ to $85^{\circ}$. Scale,

1 inch=1 mile; contour interval, 10 feet.

Map of an area in Calhoun and Eaton counties. in the western part of the Thumb Wupland. Much of the area is occupied by irregular morainal ridges and groups of small knolls 50 to 150 feet high, interspersed with numerous kettle holes, some of which contain small ponds. Much of the low ground between the morainal ridges is accupied by swamps or ponds, and most of the small streams have been artificially straightened by ditehing.

\section{Mississippi}

*Morton: Latitude, $32^{\circ} 15^{\prime}$ to $32^{\circ} 30$; longitude, $89^{\circ} 30^{\prime}$ to $89^{\circ} 45^{\prime}$. Scale, 1 inch $=1$ imile; contour interval, 20 feet.

Map of : an area in the eastern part of the Gulf Coastal Plain, between 25 and 40 miles east of Jackson, mostly in Scott Counts, though it extends westward about a mile into the eastern part of Rankin County.

* Pelahatchee: Latitude, $32^{\circ} 15^{\prime}$ to $32^{\circ} 30^{\prime}$; longitude, $89^{\circ} 45^{\prime}$ to $90^{\circ}$. Scale, 1 inch $=1$ mile; contour interval, 20 feet.

Map of parts of Rankin, Seott, and Marlison counties, in the Coastal Plain. The principal streams flow in zigzag courses on flood plains a mile or so in width, which in some rylaces ave marshy.

*Tupelo: Latitude, $34^{\circ} 15^{\prime}$ to $34^{\circ} 30^{\prime}$; longitude, $88^{\circ} 30^{\prime}$ to $88^{\circ} 45^{\prime}$. Scale, 1 inch $=1$ mile; contour interval, 20 feet.

Map of an area in Lee. Itawamba, Prentiss, and Cnion counties, near the inner margin of the Gulf Coastal Plain.

\section{Missouri}

\section{[See also Hllinois-Missouri]}

* Polo: Latitude, $39^{\circ} 30^{\prime}$ to $39^{\circ} 45^{\prime}$; longitude, $94^{\circ}$ to $94^{\circ} 15^{\prime}$. Scale, 1 inch $=1$ mile; contour interval, 20 feet.

Map of most of the western half of Caldwell County and a strip 2 to 3 miles wide along the eastern border of Clinton County near and south of Cameron. Shows also a narrow strip at the north edge of Ray County and a very small part of Dekalb County. This area lies not far east of st. Joseph in the southern part of the dissected till plains of the Central Lowland, in the region that was traversed by one or more of the oldest of the glaciers of the great ice age. Most of the drainage is tributary to Grand River, but the streams in the northwestern part flow directly to the Missouri.

\section{Montana}

State of Montana. Scale, 1 inch $=8$ miles.

Base map of the State of Montana, in two sheets, printed in two colors. Shows county boundaries, location and names of all towns and most of the smaller settlements, and railroads (in black) and rivers and many of the smaller streams and swater features (in blue). This map does not show contours.

\section{New York}

* Cattaraugus: Latitude, $42^{\circ} 15^{\prime}$ to $42^{\circ} 30^{\prime}$; longitude, $78^{\circ} 45^{\prime}$ to $79^{\circ}$. Scale, 1 inch $=1$ mile; contour interval, 20 feet.

Map of an area in Cattaraugus County, near the northwestern margin of the Allegheny Plateau. The northern and northwestern parts of the area are occupied by a huge recessional moraine, through which Cattaraugus Creek and its south branch have cut postglacial gorges, parts of which are between rock walls several hundred feet high. These gorges, although very little known, are two of the deepest of the postglacial gorges of western New York. The subcontinental divide between the drainage basins of the $\mathbf{S} t$. Lawrence and the Mississippi crosses the quadrangle from east to west in a zigzag course, Conewango, Little Valley, and other creeks in the southern part of the area being tributaries of Allegheny River, whereas Cattaraugus Creek flows to Lake Erie.

* Randolph: Latitude, $42^{\circ}$ to $42^{\circ} 15^{\prime}$; longitude, $78^{\circ} 45^{\prime}$ to $79^{\circ}$. Scale, 1 inch $=1$ mile; contour interval, 20 feet.

Map of part of Cattaraugus County, in the Allegheny Plateau. Allegheny River flows southwestward across the area. From Cold Spring a broad preglacial valley extends northwestward beyond the limits of the area. This valley is crossed neal Price Corners by the terminal moraine of the Wisconsin drift sheet that now forms the divide between Cold Spring Creek, which flows directly to the river, and Little Conewango Creek, whose waters join the river farther down after taking a devious route. The southeastern part of the area is included in the new Allegany State Park. 
* Santa Clara : Latitude, $44^{\circ} 30^{\prime}$ to $44^{\circ} 45^{\prime}$ : longitude, $74^{\circ} 15^{\prime}$ to $74^{\circ} 30^{\prime}$. Scale, 1 inch $=1$ mile; contour interval. 20 feet.

Map of an area in Franklin County, in the northern part of the Adirondacks. The area shows the effects of heavy glaciation in the rounded contour of the hills, the drift-choked and swampy vallevs, and the diverted and unsystematic drainage and it contains sereral kame and kettle moraines and some chains of eskers.

\section{Oregon}

[See also Idaho-Oregon]

"Mount Angel: Latitude, $45^{\circ}$ to $45^{\circ} 15^{\prime}$ : longitude, $122^{\circ} 45^{\prime \prime}$ to $123^{\circ}$. Scale. 1 inch $=1$ mile; contour interval, 25 feet.

Map of parts of Marion, Clackamas, and Tamhill counties, in the eastern part of the Willamette Valley. The greater part of the area is an alluvial flat that rises: from 75 feet above sea level in the northwest corner to 200 feet in the southeast corner, where a few outliers of the foothills reach altitudes of about 500 feet. The principal streams flow in meandering courses in flat-bottomed trenches 25 to 50 feet below the general level.

*Reelsport: Latitude, $43^{\circ} 30^{\prime}$ to $43^{\circ} 45^{\prime}$; longitude, $124^{\circ}$ to $124^{\circ} 15^{\prime \prime}$. Scale 1 inch $=1$ mile; contour interval, 50 feet.

Map of parts of Douglas and Coos counties, on the coast at the mouth of Umpqua: River. The greater part of the area is rather rough, being oceupied by the western foothills of the Oregon Coast Range. some peaks of which, in the southeastern part of the area, stand 1,500 feet above sea level. Along the coast is a belt about a mile wide and less than 100 feet above the sea, occupied chiefly by wind-blown sand, which has choked the mouths of sereral valleys so that they are now occupied by narrow, winding lakes. Most of the area, which is very sparsely settled, is in the Siuslaw National Forest.

State of Oregon. Scale, 1 inch $=1$ mile.

Base map of the State of Oregon, printed in two colors. Shows county boundaries, location and names of all towns and most of the smaller settlements, and: railroads (in black) and rivers and many of the smaller streams and water features (in blue). This map does not show contours.

\section{Pennsylvania}

*Howard: Latitude, $41^{\circ}$ to $41^{\circ} 15^{\prime}$ : longitude, $77^{\circ} 30^{\prime \prime}$ to $77^{\circ} 45^{\prime}$. Scale, 1 inch $=1$ mile; contour interval, 20 feet.

Map of an area in Clinton and Center connties, partly in the Allegheny Plateau and partly in the Appalachian Ranges. In the northeastern part of the area the West Branch of Susquehanna River flows in a gorge nearly 1,000 feet deep and only a mile wide at the top. The platean is bounded on the southwest by the escarp. ment of the Allegheny Front, marking an abrupt descent to the Bald Eagle Valley. Fublished also in an edition with gray overprint showing the relief by shading.

* Milton: Latitude, $41^{\circ}$ to $41^{\circ} 15^{\prime}$; longitude, $76^{\circ} 45^{\prime}$ to $77^{\circ}$. Scale, 1 inch $=1$ mile; contour interval, 20 feet.

Map of an area that includes parts of Lycoming, Union, NorthumberIand, and Montour counties, in the Appalachian Valley beIt southeast of Williamsport. The quadrangle is crossed by the West Branch of Susquehanna River, which flows at levels between 430 and 500 feet above the sea. State Highway No. 18: runs southeastward from Williamsport to Muncy and thence southward through the Muncy IIills to Milton, and the valley of the river is traversed by railroads.

* Shippensburg: Latitude, $40^{\circ}$ to $40^{\circ} 15^{r}$; longitude, $77^{\circ} 30^{\prime}$ to $77^{\circ} 45^{\prime \prime}$. Seale, 1 inch $=1$ mile; contour interval, 20 feet.

Map of an area in Franklin, Cumberland. Perry, and Huntingdon counties, im the Appalachian Valley and Ranges. The extreme southeast corner of the area lies on the lowermost slope of the northwestern base of South Mountain.

* Trout Run: Latitude, $41^{\circ} 15^{\prime}$ to $41^{\circ} 30^{\prime}$; longitude, $77^{\circ}$ to $77^{\circ} 15^{\prime \prime}$. Scale; 1 inch $=1$ mile; contour interval, 20 feet.

Map of an area in Lycoming Connty, partly in the Allegheny Platear and partly in the Appalachian Valley belt. The surface of the plateau is trenched by the deep gorge of Lycoming Creek, which at some places reaches a depth of 1,500 feet, and by many smaller valleys and ravines. The Allegheny Front crosses the area a little south of its center as a bold escarpment 600 to 900 feet high. The extreme southeast corner of the area, less than f00 feet above sea level, is in the valley of the West Branch of Susquehanna River:

* Tyrone: Latitude, $40^{\circ} 30^{\prime}$ to $40^{\circ} 45^{\prime}$; long tude, $78^{\circ}$ to $78^{\circ} 15^{\prime}$. Scale, 1 inch $=$ 1 mile; contour interval, 20 feet.

Map of an area in Huntingdon, Blair, and Center counties, among the Appalachian Ranges. The north-central part of the area is accupied by the broad Nittany Valley. On the northwest the Nittany Valley is separated from the Bald Eagle Valley by the nearly even-crested ridge of Bald Eagle Mountain, which rises to 1,800 feet in some points. The northwest corner of the area lies at an altitude of 2,360 feet on the crest of the Allegheny Front. Juniata River and the Frankstown Branch of that stream cross the area in narrow, steep-walled trenches and cut through Bald Eagle and Tussey mourtains in deep gorges.. Published also in an edition with gray overprint showing the relief by shading. 
Texas

* Ketchum Mountains: Latitude, $31^{\circ} 15^{\prime}$ to $31^{\circ} 30^{\prime}$; longitude, $101^{\circ}$ to $101^{\circ} 15^{\prime}$. Scale, 1 inch=1 mile; contour interval, 25 feet.

Map of an area in Irion County, in the Texas Hill section of the Great Plains. The southeastern part of the area lies on the northern fringe of the Edwards Plateau. The remainder of the area is chiefly a lower upland, whose surface is cut into irregular mesas by Middle Concho River, the only permanent stream in the area.

Lopena Island: Latitude, $26^{\circ} 45^{\prime}$ to $27^{\circ}$; longitude, $97^{\circ} 15^{\prime}$ to $97^{\circ} 30^{\prime}$. Scale, 1 inch $=1$ mile; contour interval, 5 feet.

Map of part of Kenedy County, on the Gulf coast near the southern corner of the State. Only in the western half of the area is there land, and most of this part consists of a tidal flat, Laguna Madre, which is separated from the Gulf by the long barrier beach called Padre Island.

* Saltillo Ranch: Latitude, $26^{\circ} 45^{\prime}$ to $27^{\circ}$; longitude, $97^{\circ} 30^{\prime}$ to $97^{\circ} 45^{\prime}$. Scale, 1 inch $=1$ mile; contour interval, 5 feet.

Map of part of Kenedy County, in the Gulf Coastal Plain. The land surface of the area, which is everywhere less than 50 feet above sea level, is crossed by a maze of small, roughly linear southeastward-trending ridges and hollows. Apparently all the inequalities in the relief of the area are due to the work of the wind. The area contains no streams. Its eastern part is occupied by the tidal flat of Laguna Madre.

* Sierra Madera: Latitude, $30^{\circ} 30^{\prime}$ to $30^{\circ} 45^{\prime}$ : longitude, $102^{\circ} 45^{\prime}$ to $103^{\circ}$. Scale, 1 inch $=1$ mile; contour interval, 25 feet.

Map of part of Pecos County, in the eastern part of the trans-Pecos country. Most of the area is occupied by several irregular groups of small mountains which are separated and sourrounded by sloping plains.

\section{Vermont}

*Camels Hump: Latitude, $44^{\circ} 15^{\prime}$ to $44^{\circ} 30^{\prime}$; longitude, $72^{\circ} 45^{\prime}$ to $73^{\circ}$. Scale, 1 inch $=1$ mile; contour interval, 20 feet.

Map of parts of Chittenden, Washington, Addison, and Lamoille counties, in the Green Mountains. Camels Hump. 4,083 feet above sea level, in the south-central part of the area, is one of the highest points in the State. Winooski River flows northwestward across the center of the area in a remarkably straight gorge cut down to about 400 feet. A narrow strip of flood plain in the bottom of the gorge is traversed by the Central Vermont Railway and the Theodore Roosevelt International Highway, and the Green Mountain Club trail has been laid out along or near the erest of the main range of the mountains.

\section{Virginia}

[See West Virginia-Virginia]

\section{Washington}

Corfu: Latitude, $46^{\circ} 45^{\prime}$ to $47^{\circ}$; longitude, $119^{\circ} 15^{\prime}$ to $119^{\circ} 30^{\prime}$. Scale, 1 inch $=1$ mile; contour interval, 25 feet.

Map of an area in Grant and Adams counties, in the Walla Walla Plateau portion of the Clolumbia Plateaus. The entire area is a part of a great lava plateau. Two great ridges of lava cross the area from east to west. The Frenchman Hills, in the northern part, reach an altitude of 1,740 feet above sea level at one point, and the Saddle Mountains, in the southern part, reach altitudes of 2,000 and 2,200 feet in several peaks. Crab Creek flows southward and westward across the area, in a large valley that was occupied by Columbia River in late Pleistocene time. The northern part of the area is a portion of the bed of a late Pleistocene lake, now largely floored with drifting sand.

\section{West Virginia}

* Alderson : Latitude, $37^{\circ} 30^{\prime}$ to $37^{\circ} 45^{\prime}$; longitude, $80^{\circ} 30^{\prime}$ to $80^{\circ} 45^{\prime}$. Scale, 1 inch $=1$ mile; contour interval, 50 feet.

Map of an area in Monroe, Summers, and Greenbrier counties, in the Greenbrier Basin section of the Appalachian Ranges. The area is a confused maze of short, irregular ridges trending in different directions. A belt in the eastern part contains many sink holes. Greenbrier River crosses the northern part of the area.

*Callaghan: Latitude, $37^{\circ} 45^{\prime}$ to $38^{\circ}$; longitude, $80^{\circ}$ to $80^{\circ} 15^{\prime}$. Scale, 1 inch $=1$ mile; contour interval, 50 feet.

Map of part of Greenbrier County. W. Va., among the Appalachian Ranges, several of which cross the area from northeast to southwest. Allegheny Mountain, along whose crest the State boundary lies, here forms the divide between the streams flowing to the ohio and those flowing to the Atlantic. 
*Capon Bridge: Latitude, $39^{\circ} 15^{\prime}$ to $39^{\circ} 30^{\prime}$; longitude, $78^{\circ} 15^{\prime}$ to $78^{\circ} 30^{\prime}$. Scale, 1 inch $=1$ mile; contour interval, 50 feet.

Map of an area in Hampshire and Morgan counties, among the Appalachian Ranges, a number of which trend north-northeastward across it. Cacapon Mountain, the highest, stands 2,550 feet above sea level at one point, and the crests of other ridges range from 1,500 to 2,300 feet. Cacapon River flows northward through the area.

* Clintonville: Latitude, $37^{\circ} 45^{\prime}$ to $38^{\circ}$; longitude, $80^{\circ} 30^{\prime}$ to $80^{\circ} 45^{\prime}$. Scale, 1 inch $=1$ mile; contour interval, 50 feet.

Map of an area in Greenbrier and Summers counties, partly in the Kanawha Hills section of the Allegheny Plateau and partly in the Greenbrier Basin section of the Appalachian Ranges. A group of mountains, which culminates at 4,035 feet above sea level in Cross Mountain, occupies the northeastern part of the area ; and a similar group, which culminates at 3,945 feet in Keeney Knob, occupies the southwestern part. Meadow River flows across the area in a flood plain that is in some places more than a mile wide. The southeastern part of the area is crossed by James River and by Kanawha Turnpike, the principal and oldest highway across the mountains of central West Virginia. Published also in an edition with gray overprint showing the relief by shading.

* Edinburg: Latitude, $38^{\circ} 45^{\prime}$ to $39^{\circ}$; longitude, $78^{\circ} 30^{\prime}$ to $78^{\circ} 45^{\prime}$. Scale, 1 inch $=1$ mile; contour interval, 50 feet.

Map of a small area in the Appalachian Ranges, in Hardy County, W. Va.

* Hanging Rock: Latitude, $39^{\circ} 15^{\prime}$ to $39^{\circ} 30^{\prime}$; longitude, $78^{\circ} 30^{\prime}$ to $78^{\circ} 45$. Scale, 1 inch $=1$ mile; contour interval, 50 feet.

Map of an area in Hampshire and Mineral counties, among the Appalachian Ranges. The South Branch of Potomac River flows in a sinuous course northeastward across the northwestern part of the area.

* Middletown: Latitude, $39^{\circ}$ to $39^{\circ} 15^{\prime}$; longitude, $78^{\circ} 15^{\prime}$ to $78^{\circ} 30^{\prime}$. Scale, 1 inch $=1$ mile; contour interval, 50 feet.

Map of an area in Hampshire County among the Appalachian Ranges. The,area is crossed by two mountain ranges whose crests rise 1,400 to 2,800 feet above sea level. Between them, at a general altitude of about 1,200 feet, lies the valley of Cacapon River, which is cut by the immediate trench of the river, about 400 feet deep and half a mile wide.

* Orkney Springs: Latitude, $38^{\circ} 45^{\prime}$ to $39^{\circ}$; longitude, $78^{\circ} 45^{\prime}$ to $79^{\circ}$. Scale, 1 inch $=1$ mile; contour interval, 50 feet.

Map of an area in Hardy County, W. Va., among the Appalachian Ranges, several of which cross the area mapped. The crests of the ranges stand 2,200 to 3,200 feet above sea level. Moorefield and Lost rivers flow northeastward in valleys 1,000 feet or more deep, and several tributaries of Lost River cut through some of the ranges in deep gorges.

* Pearisburg: Latitude, $37^{\circ} 15^{\prime}$ to $37^{\circ} 30^{\prime}$; longitude, $80^{\circ} 30^{\prime}$ to $80^{\circ} 45^{\prime}$. Scale, 1 inch $=1$ mile; contour interval, 50 feet.

Map of part of Monroe County, W. Va., among the Appalachian Ranges, two of which cross the area mapped. Peters Mountain, along whose crest the State bound ary lies, stands 3,400 to 4,000 feet above sea level. The northwest corner of the area stands 2,100 to 2,300 feet above sea level and is cut by small valleys about 200 feet deep.

* Richwood: Latitude $38^{\circ}$ to $38^{\circ} 15^{\prime}$; longitude, $80^{\circ} 30^{\prime}$ to $80^{\circ} 45^{\prime}$. Scale, 1 inch $=1$ mile; contour interval, 50 feet.

Map of an area in Greenbrier and Nicholas counties, in the Kanawha Hills section of the Allegheny Plateau.

* White Sulphur Springs: Latitude, $37^{\circ} 45^{\prime}$ to $38^{\circ}$; longitude, $80^{\circ} 15^{\prime}$ to $80^{\circ} 30^{\prime}$. Scale, 1 inch $=1$ mile; contour interval, 50 feet.

Map of an area in Greenbrier County, mainly in the Greenbrier Basin section of the Appalachian Ranges. The plateau surface is trenched to a depth of 100 to 200 teet by the narrow, $V$-shaped valleys of a few small streams, but sink holes abound and the drainage of a large part of the surface is underground. The eastern third of the area is occupied by the ranges of Greenbrier and other mountains. The extreme southeast corner of the area is crossed by the ridge of Allegheny Mountain, which forms the divide between the drainage flowing to the Ohio and that flowing directly to the Atlantic; beneath this ridge passes the Allegheny tunnel of the Chesapeake \& Ohio Railway. Greenbrier River flows southward across the middle of the area in a meandering trench incised 300 to 500 feet in the plateau.

\section{West Virginia-Virginia}

* Ronceverte: Latitude, $37^{\circ} 30^{\prime}$ to $37^{\circ} 45^{\prime}$; longitude, $80^{\circ} 15^{\prime}$ to $80^{\circ} 30^{\prime}$. Scale, 1 inch $=1$ mile; contour interval, 50 feet.

Map of parts of Monroe and Greenbrier counties in West Virginia and Craig and Alleghany counties in Virginia, among the Appalachian Ranges. The northwestern part of the area lies in the broad basin of Greenbrier River. Published also in an edition with gray overprint showing the relief by shading. 


\section{Wisconsin}

[See also Illinois-Wisconsin.]

* Blanchardrile: Latitude, $42^{\circ} 45^{\prime}$ to $43^{\circ}$; longitude, $89^{\circ} 45^{\prime}$ to $90^{\circ}$. Scale, 1 inch $=1$ mile; contour interval, 20 feet.

Map of parts of Iowa, Dane, Lafayette, and Green counties, in the Driftless Area.

\section{Wisconsin-Illinois}

* South Wayne: Latitude, $42^{\circ} 30^{\prime}$ to $42^{\circ} 45^{\prime}$; longitude, $89^{\circ} 45^{\prime}$ to $90^{\circ}$. Scale, 1 inch $=1$ mile; contour interval, 20 feet.

Map of parts of Lafayette and Green counties, Wis., and Stephenson and Jo Daviess counties, Ill., in the Driftless Area. Pecatonica River and its East Branch cross the area in meandering courses in flat-bottomed valleys half a mile wide and 150 to 200 feet deep.

\section{GEOLOGIC BRANCH}

SCOPE AND ORGANIZATION OF WORK

The field and laboratory work of the geologic branch should logically be coextensive with the science of geology. The fundamental principles of the science are now more firmly established and more broadly applicable than ever before, and intense specialization in many fields, in harmony with that prevailing in all scientific research, is constantly accelerating the growth of geology and increasing its useful applications. Ideally the work of the Geological Survey should embrace all fields of geologic research and should keep pace with the progress of the science. Practically, in view of the limits imposed upon personnel and funds and laboratory space, this ideal is unattainable. The efforts of the organization are therefore directed mainly to the performance of work that will be of greatest obvious public benefit. A balance is struck between fundamental research that may yield practical results only after many years and the solution of special problems by work whose results are without doubt immediately useful.

The Geological Survey cooperates actively with other Government bureaus, with most of the State geological surveys, with many of the geologic faculties of the universities, and with several of the great endowed research institutions. Through correlated research, attendance at scientific congresses, interchange of ideas, and conjoined effort the many workers in this branch of science bring to the solution of current practical problems the best geologic thought of the day.

Field and laboratory investigations in many departments of geology are made. The field studies yield geologic maps showing stratigraphy and structure and interpretative reports on such subjects as glaciology and physiography; work done in field and laboratory yields results in paleontology, mineralogy, petrography, chemistry, and physics; and combinations of all these results are used in solving practical problems connected, for example, with the occurrence, reserves, and availability of fuels, minerals and water resources, the strength of foundations of dams, or the suitability of reservoir sites. The work done yields by-products that are of present scientific value or of ultimate practical application, though between the two classes no sharp line of demarcation can be drawn. for the scientific theory of to-day governs the business practice of to-morrow.

Statistical compilations of mineral production and resources are directed to the solution of problems of mineral economics. The ideal 
here is to use specialists geologically trained in order that a knowledge of such fundamental factors as reserves (both domestic and foreign), markets, and general business conditions may be intelligently correlated and interpreted to yield an invaluable fund of useful information. It is unfortunate that money is not available to enable the Survey to attain this ideal throughout the work, for mere statistics without such a setting are of correspondingly less value.

Research work in chemistry and physics supplements and supports geologic work. Many of the most practical geologic investigations could not be carried on without such aid.

The work of the geologic branch is performed through three coordinate divisions-geology, chemical and physical research, and mineral resources. The general organization during the fiscal year has been as follows:

Geologic branch: W. C. Mendenhall, chief geologist.

Division of geology: W. C. Mendenhall, geologist in charge.

Division of mineral resources: G. F. Loughlin, geologist in charge until May 15 ; F. J. Katz, geologist in charge from May 15 to June 30.

Division of chemistry and physies: George Steiger, chief chemist, acting in charge.

\section{APPROPRIATIONS}

The act making appropriations for the Department of the Interior for the fiscal year ending June 30, 1924, carried four items, aggregating $\$ 484,950$, by which the work of the geologic branch was maintained. In addition, geologic field work required for the classification of mineral lands was done by means of the appropriation made for the classification of the public lands, at a total cost of $\$ 44,000$. By comparison with the amounts appropriated for similar work in the preceding fiscal year the figures given show a decrease of $\$ 750$ in the amount available for work on mineral resources and an increase of $\$ 10,350$ in the amount available for land classification.

The Geological Survey cooperates with other organizations, State and Federal, by assigning its members to the study of special problems, either wholly at the expense of the organization that requires the cooperation or by sharing the cost of the work. The Forest Service, the General Land Office, the Office of Indian Affairs, the Department of Justice, the Bureau of Reclamation, and several States thus received the benefit of the special training available in the branch. The cost to the cooperating organizations during the fiscal year, either in the form of salaries assumed or field expenses borne, was $\$ 16,000$ (repay work $\$ 6,600$, cooperating States $\$ 9,400$ ). The total amount made available to the branch for the fiscal year, including direct appropriations, allotments for land classification, and cooperative funds, was thus $\$ 544,950$.

\section{DIVISION OF GEOLOGY}

\section{ORGANIZATION AND PERSONNEL}

The division of geology as at present organized includes the ten sections indicated below. It also exercises technical supervision over the section of geologic map editing, a part of the publication branch. 
Geology of metalliferous deposits: F. L. Ransome, geologist in charge until May 15, 1924; G. F. Loughlin, geologist in charge from May 15 to June 30.

Paleontology and stratigraphy: 'T. W. Stanton, geologist in charge.

Glacial geology: W. C. Alden, geologist in charge.

Geology of iron and steel metals : E. F. Burchard, geologist in charge.

Coastal Plain investigations: L. W. Stephenson, geologist in charge.

Areal geology: Sidney Paige, geologist in charge.

Geology of nonmetalliferous deposits: G. R. Mansfield, geologist in charge.

Petrology : E. S. Larsen, jr., geologist in charge until October 1, 1923; C. S.

Ross, geologist acting in charge from October 1, 1923, to June 30, 1924.

Geology of oil and gas fields: K. C. Heald, geologist in charge.

Geology of coal fields: W. T. Thom, jr., geologist in charge.

In addition to the units of administrative organization the division includes two advisory committees-the committee on geologic names, T. W. Stanton, chairman, and the physiographic committee, M. R. Campbell, chairman. These committees consider in detail all problems falling within their respective fields and advise the chief geologist of their findings as a basis for administrative action.

At the beginning of the fiscal year the division included 124 geologists of various grades. During the year 5 resigned, 1 retired, 1 was transferred to another branch, and 15 were added, so that the number employed at the end of the year was 132. The division ineluded also 5 draftsmen and 7 preparators of fossils and skilled laborers. In the clerical force there were 4 accessions and 3 separations, and the number employed at the end of the year was 31 .

The resignation of Frederick Leslie Ransome, who had directed the work of the section of metalliferous deposits since 1912, is a great loss to the Survey. Doctor Ransome resigned to become professor of economic geology at the University of Arizona.

T. Wayland Vaughan and Esper S. Larsen, jr., each distinguished in his own field of work, have also left the Survey, Doctor Vaughan to become Director of Scripps Institute at Palo Alto, Calif., and Doctor Larsen to become professor of petrology at Harvard University.

J. S. Diller retired from the Survey December 31, 1923, after 40 years of active service.

B. S. Butler was reinstated as a member of the Survey April 16, 1924 , after four years of service in economic research concerning eopper deposits in Michigan under the auspices of Harvard University and the Calumet \& Hecla Mining Co.

\section{ALLOTMENTS AND EXPENDITURES}

The funds available for the work of the division of geology for the fiscal year were as follows:

Geologic surveys

Classification of lands $\$ 300,000$

Scientific assistants 44,000

Search for potash deposits (allotted from the appropriation for chemical and physical research) 17,700

Repayments on account of work done for other Government establishments or other Geological Survey units_.

6,600 
The expenditures from these funds may be classified by subjects approximately as follows:

Economic geology of metalliferous deposits $\$ 31,300$

Economic geology of nonmetalliferous deposits______.___ 15,500

Economic geology of fuels (oil, gas, coal) _..._._. 95,000

Scientific researches not directly connected with economic geology (paleontology, glaciation, Coastal Plain formations, etc.)

Supervision, administration, salaries of clerical, technical, and skilled-labor forces, purchase and repair of instruments, office supplies, etc.

Reserve and balance 106,500

Of the amounts available for geologic work, approximately $\$ 84,000$ was used directly to pay field expenses, including those incurred in the search for potash. About 65 per cent of this amount was expended for work done west of the one hundredth meridian and about 35 per cent for work done east of it.

\section{COOPERATION}

By cooperation, formal or informal, with State geological surveys, research institutions, and other organizations the sum of geologic work accomplished during the year is materially increased. Examples of such cooperative work with State surveys are the completion of a geologic map of Arizona, the preparation of a revised geologic map of Alabama, the preparation of a map and report on the geology and oil possibilities of Russell County, Kans., the preparation of a bulletin on the physiography of Georgia and of another on the stratigraphy of Mississippi (all these to be published by the States), and the preparation of a report on the ground waters of Mississippi to be published by the United States Geological Survey. A report on the Valley coal fields of Virginia, in preparation, is to be published by the State.

The publication of the English edition of a report on the geology of Haiti completes part of an important cooperative work, the expenses of which were borne by the Haitian Grovernment. The French edition is now in type.

The identification of fossils sent in from different parts of the United States and from the West Indies and Central and South America is a cooperative service of great usefulness to State surveys and to the oil industry. Studies of Samoan fossils were made in cooperation with the Carnegie Institution of Washington.

A detailed study of the San Andreas rift, in southern California, is being made by L. F. Noble as the Survey's part of cooperative rearthquake studies under the auspices of the Seismological Society of America. The Carnegie Institution and the Coast and Geodetic Survey are each carrying on coordinated parts of this work.

In its capacity as expert adviser in the solution of problems involving geology and mineral economics the cooperation of the Survey is increasingly requested by many Federal departments. Such cooperation was maintained with the Office of Indian Affairs in 
matters involving the leasing of oil lands, with the Bureau of Reclamation in the examination of reservoir and dam sites, and with the Forest Service in the examination of lands proposed for purchase under the Appalachian National Forest Act. Assistance has been given to the Department of Justice, and a report on the zinc deposits of the world is being prepared for the Department of Commerce.

Through the service of the Director as a member of the United States Coal Commission the largest possible use was made of the Survey's data and personnel in an inquiry of dominant public interest. Similar cooperation has resulted from his appointment on the President's Taval Oil Commission.

\section{GENERAL REVIEW OF WORK OF THE YEAR}

Partly, perhaps, because the adjustment of Government salaries to new price levels lags somewhat behind such adjustment in outside institutions, but largely because the Survey has always been compelled to surrender its trained specialists to commercial companies and educational institutions, separations from the technical force have continued. Two universities and one research institution have taken three men, each difficult to replace in his particular field.

The work of the year, which is set forth below in detail by States, was, as heretofore, so directed as to assist the economical development of the country's mineral resources. It is gratifying, however, to note that many so-called "purely scientific" investigations are byproducts of the rork of solving "practical" problems and derive a large part of their value from their connection with that work.

Although the limit placed on the funds available for the classification of millions of acres of withdrawn coal lands prevents rapid progress in that work, it nevertheless goes steadily forward from year to year. In connection with this work certain kinds of research concerning coal are pressingly demanded, such as research as to its nature and composition, its origin, and its special fitness for use in particular industries. So far as money and personnel will permit, such research is being made, for the ever-increasing demand for power implies the necessity for a more intelligent and therefore more economical use of the heat units in coal, now so lamentably wasted.

The intensive study of oil fields continues, and more general surveys designed to outline favorable territory have been made, notably in the Northwest. The classification of oil lands by the Survey must be based upon accurate geologic information and can not proceed faster than the information is accumulated. Research here also follows closely the pressing need for accurate information. The employment of more refined methods of study - by means of the microscope, for example - in discovering the distinguishing characteristics of key strata has been considerably increased and has afforded better interpretations of well logs, with all the advantages that follow this method of ascertaining underground structure in regions where surface exposures are inadequate.

Throughout the year a form of research that had been neglected temporarily-the study of the nature and origin of oil shale-has been carried on. Field studies leading to a clearer understanding of 
the conditions under which oil shales were laid down have been coupled with laboratory research-by the microscope and by chemical, biological, and botanical studies-in attempts to determine the constitution of oil shale, not only with reference to its commercial use but with reference to its bearing on the origin of oil. The results of these studies will certainly promote a more intelligent search for oil when failing supplies necessitate the location of the less easily exploited sources.

An investigation of unusual interest embraces the folded, faulted, and possibly oil-bearing belt that surrounds the Bearpaw Mountains, in Montana. Here the complexity, not of the observed facts but of the theoretical considerations that will determine a correct interpretation of underground structure - the shape and depth of folds and faults - is an illustration of the need for fundamental studies of the mechanics of the earth's crust.

In the study of metalliferous deposits two investigations, it is hoped, will throw light on the occurrence of gold and copper-one a critical study of the quartz veins of the Mother Lode, CaliA, where apparently significant relations between ore shoots and barren veins have yet to be made out; the other a thorough study, surface and underground, of the Michigan copper country. The investigation in Michigan, begun by private companies actuated by enlightened selfinterest, was carried out by them in a thoroughly scientific manner at great expense. Through their generosity the results of this work will be embodied in a report covering a much wider area. These results should be of great scientific and practical value.

In Nevada broad areal, structural, and economic studies in the Basin Range province continue to throw light on a little-known region, with the unexpected result that the older conception of widely prevalent simple block faulting is being supplanted by a conception of complicated overthrust faults and folds.

Investigation to discover deposits of potash has centered largely in southwestern Texas. Here the discovery of potash in well after well, the definite recognition of a potash-bearing mineral (polyhalite), the presence of potash of commercial grade, and the prospects of finding commercial deposits of potash similar to those of Germany and Alsace are all encouraging. In this work the Survey maintains cooperation with drillers and with oil companies operating in the region. Samples are collected and studied in the field and sent to Washington for analysis.

Among the papers published during the year is one entitled "The evolution and disintegration of matter," by F. W. Clarke (Professional Paper 132-D), which summarizes the progress of research that has led to the conclusion that the so-called chemical elements have originated by a definite evolutionary process and that this process may be reversible.

Three papers on coal, one on the Twentymile Park district of the Yampa coal field, Colorado (Bulletin 748), one on the Tullock Creek coal field, Montana (Bulletin 749), and one on the Raton coal field, New Mexico (Bulletin 752), were published during the year.

A progress report on a subsurface study of the Pershing oil and gas field, in Oklahoma (Bulletin 751-B), is of special interest. 
The following reports, published during the year, are of special interest to the mining industry:

Geology and ore deposits of the Creede district, Colo. (Bulletin 718).

Geology and ore deposits of the Manhattan district, Nev. (Bulletin 723).

Origin of certain rich silver ores near Chloride and Kingman, Ariz. (Builetin $750-\mathrm{B})$.

A report on the lime belt of Massachusetts and parts of eastern New York and western Connecticut was published as Bulletin 744 .

A publication that will be welcomed by all geologists is a bibliography and index of geologic literature on North America from 1785-1918 (Bulletins 746 and 747).

\section{WORK OF THE YEAR BY STATES}

\section{ALABAMA}

Field work--E. F. Burchard examined bauxite deposits in northwesterm Alabama and conferred with geologists and mining men at Birmingham in connectign with the compilation of additional geologic data on the iron ores of the Birmingham district. Charles Butts, in cooperation with the Geological Survey of Alabama, examined the Paleozoic areas of Alabama for a revision of the geologic map of the State. G. R. Mansfield examined a deposit of arsenopyrite near Cragford and conferred with its operators at Birmingham regarding its features. He also visited the plant of the Federal Phosphorus Co. at Anniston to study the method of manufacturing ferrophosphorus and phosphoric acid in the electric furnace.

Office work.-Work on a revised geologic map of Alabama, to be issued by the State in cooperation with the United States Geological Survey, is being carried on by L. W. Stephenson, C. W. Cooke, and Charles Butts, Messrs, Stephenson and Cooke determining the boundaries of the Upper Cretaceous, Tertiary, and Quaternary formations that crop out in the Coastal Plain and Mr. Butts studying the Paleozoic areas in the northern part of the State. G. R. Mansfield prepared a short report on the occurrence of arsenopyrite near Cragford. A paper on the Mississippian formations of the Tennessee Valley in northern Alabama is in preparation by Charles Butts. R. D. Mesler studied several collections of fossils from Alabama for comparison with similar faunas of other areas. M. N. Bramlette made a stratigraphic study of formations that may carry oil in northwestern Alabama.

\section{ARIZONA}

Field work.-N. H. Darton, in cooperation with the Arizona Bureau of Mines, made additional field studies in connection with the preparation of a geologic map of Arizona and a report on the physiography of the State. W. T. Thom, jr., in cooperation with H. I. Smith, of the United States Bureau of Mines, made an examination of the coal mines at the Keams Canyon Agency in northeastern Arizona for the Office of Indian Affairs, to determine the quantity of coal available there and the best method of mining it. $H$. A. C. Jenison continued his study of the geology of proposed dam sites on Colorado River in Boulder and Black canyons and of the valuation of mines and prospects adjacent to these sites. Edward Sampson made studies of the asbestos deposits near Globe. G. I. Finlay, assisted by Carle H. Dane, began work on the Four Corners project, their initial work being adjacent to the Gypsum Creek anticline.

Office work.-F. L. Ransome continued work on his detailed report on the geology and ore deposits of the Oatman district and made some additions to his general report on the geology and ore deposits of Arizona. N. H. Darton compiled supplemental data for the cooperative geologic map of Arizona and made some progress on a bulletin on the physiography of the State. A report by Waldemar Lindgren on the ore deposits of the Jerome and Bradshaw Mountain quadrangles, Yavapai County, was completed and transmitted for publication. Edward Sampson prepared a review of a paper by A. M. Bateman on asbestos of Arizona. P. V. Roundy studied cuttings from a well drilled for oil in northcentral Arizona, and K. C. Heald and J. G. Douglas studied cuttings from a 
well on Gypsum Creek. T. W. Stanton, G. H. Girty, and Edwin Kirk studied and reported on Cambrian, Carboniferous, and Cretaceous fossils from the State. E. F. Burchard and G. F. Loughlin made a study of materials from dam sites in Arizona for the Bureau of Reclamation. W. T. Thom, jr., prepared, for transmission to the Office of Indian Affairs, a report giving the results of the examination of coal mines at the Keams Canyon Agency.

Publications.-Bulletin 750-B, Geologic Folio 217.

ARKANSAS

Field work.-H. D. Miser examined the manganese deposits of the Batesville district, Ark., inspected diamond-bear ng rocks near Murfreesboro, conferred with operators of diamond mines at Murfreesboro, and collected fossil plants from a sandy shale near Gilham. H. D. Miser and C. S. Ross studied the Upper Cretaceous tuff and ash beds in southwestern Arkansas. Julia Gardner made a short field trip in Arkansas with the Shreveport branch of the Southwestern Genlogical Society. E. O. Ulrich and R. D. Mesler made studies of Paleozoic stratigraphy in the vicinity of Black Rock and Batesville.

Office work.-G. H. Girty continued work on his report on the fauna of the Morrow formation of Arkansas. C. S. Ross revised his paper on diamonds in Arkansas for publication in a report of the Smithsonian Institution and began to prepare a report on the volcanic tuffs and ash of the Upper Cretaceous rocks of southwestern Arkansas. H. D. Miser wrote a paper entitled "Diamondbearing peridotite in Pike County, Ark.," for publication in the appendix to the annual report of the Smithsonian Institution for 1923 . E. W. Berry has in preparation a report on additions to the Wilcox flora, which includes material from Arkansas. T. W. Stanton and G. H. Girty studied and reported on Cretaceous and Carboniferous fossils from the State. K. C. Heald and H. D. Miser studied drill cuttings from wells in southern and southwestern Arkansas for purposes of correlation.

Publication.-Geologic Folio 215.

\section{CALIFORNIA}

Field work.-F. E. Matthes completed a physiographic reconnaissance of the upper San Joaquin basin, Calif. W. S. W. Kew completed field work on the geology of the oil fields of southern Los Angeles County, revised his work in the San Pedro Hills and Inglewood Hills, and inspected fossil human remains. found near Santa Barbara. L. F. Noble continued his studies of the San Andreas rift zone, investigated the Kramer borate deposits, and visited the plants of the Burnham Chemical Co. and American Trona Corporation, at Searles Lake. W. P. Woodring and P. V. Roundy, assisted by H. W. Hoots, began a geologic study of Naval Reserve No. 1. Adolph Knopf, assisted by T. B. Nolan, resumed field work in the Mother Lode district in cooperation with the State.

Office work.-W. A. English submitted a report on the oil resources of the Puente Hills (Bulletin 768). W. S. W. Kew completed reports on the San Pedro Hills, Los Angeles County, and on the geology and oil prospects of the Inglewood Hills district, studied data on the Inglewood earthquake, and compiled a map of southern California. F. E. Matthes continued work on the physiography of the upper San Joaquin basin, revised a report on the origin of Yosemite Valley, and prepared other papers for outside publication. F. C. Calkins continued the preparation of a report on the bedrock of the Yosemite region. L. F. Noble prepared a report on the Kramer borate deposits and worked on a report on the San Andreas rift. W. H. Dall revised a report by T. Oldroyd on the Pleistocene fossils of San Pedro and reported on Pleistocene, Eocene, Pliocene, and other fossils. Adolph Knopf prepared a paper on the Mother Lode for unofficial publication. Robin. Willis submitted a report on the geology of the San Andreas fault from San Juan Bautista to the Cholame Plains.

COLORADO

Field work.-J. D. Sears, assisted by P. C. Benedict and Q. D. Singewald, examined coal lands on Vermilion Creek, Colo., for land classification. Messrs. Sears, Mather, Gilluly, and Lusk did reconnaissance geologic mapping in northeastern Colorado. J. B. Eby continued examinations of the eastern part of the Yampa coal field and examined numerous tracts in adjacent areas for land classification. Mr. Eby visited and sampled mines at Mount Harris and. in 
company with J. B. Reeside, jr., and C. E. Dobbin, made a trip through parts of northwestern Colorado and southern Wyoming to study the correlation of the coal-bearing and related formations. W. W. Boyer reexamined parts of the Grand Mesa coal field and examined tracts in La Plata, Las Animas, and Huerfano counties for land classification. He also inspected reported gas wells in San Luis Valley and the area corered by an oil-prospecting permit. C. D. Avery inspected drilling operations near Loveland and Fort Collins and collected well data in Denver. F. L. Hess examined platinum, uranium, and vanadium deposits in Colorado. W. H. Bradley began investigations of oil shale in Rio Blanco and Garfield counties. Adolph Knopf reexamined the Aspen district with a view to giving advice on the possible extension of mining.

Office work,-C. W. Cross, E. S. Larsen, C. S. Ross, and Kirtley Mather continued work on reports on the geology of the San Juan region. G. F. Loughlin continued the revision of the monographic report on the Leadville district that was left incomplete in 1917 by the death of Capt. J. D. Irving. Adolph Knopf completed a report entitled "Notes on the Aspen district." A report by E. T. Hancock on the economic geology of the Meeker quadrangle was revised by W. T. Thom, jr., assisted by J. B. Eby, and a report on the geology of the Axial and Monument Butte quadrangles (Bulletin 757), by E. T. Hancock, was revised by J. D. Sears, W. T. Thom, jr., and J. B. Eby. Mr. Eby nearly completed a report on the eastern part of the Yampa coal field and prepared a press notice on the Elkhead district, in that field. J. D. Sears revised his report on oil prospects in a part of Moffat County (Bulletin 751-G), and prepared a paper on the Browns Park formation and Bishop conglomerate for outside publication. J. B. Reeside, jr., prepared a report on the geology of Green River valley, Wyoming. Colorado, and Utah, for inclusion in a paper by R. R. Woolley on power sites and revised parts of a report on the Cretaceous and Tertiary formations of the western part of the San Juan Basin, in Colorado and New Mexico. T. W. Stanton made a preliminary report on Upper Cretaceous invertebrates from Colorado. K. C. Heald prepared a press bulletin entitled "Promising places for oil in Moffat County, Colorado," covering the Hamilton dome and Seeping Spring Gulch dome. G. H. Girty, F. H. Knowlton, and J. B. Reeside, jr., prepared paleontologic reports on material from Colorado.

Publications.-Bulletins 718,748 ; press notices on coal in the Elkhead district of the Yampa coal field (No. 16653) and promising places for oil in Moffat County (No. 16037).

\section{CONNECTICUT}

Publication.-Bulletin 744 .

DISTRICT OF COLUMBIA

Field work.-Laurence La Forge worked in the District of Columbia in connection with a geographic handbook of Virginia.

FLORIDA

Field work.-Julia Gardner continued a study of lower Miocene formations in Florida, chiefly in Walton and Washington counties, in informal cooperation with the State. C. W. Cooke examined some islands in Lake Worth with respect to age, for the General Land Office, and began geologic studies near Tallahassee and Marianna. J. T. Pardee supervised the classification of phosphate land in Polk, Marion, Hillsborough, Leon, and Jefferson counties.

office work.-Julia Gardner completed the preparation of the third part of her paper on the mollusks of the Alum Bluff formation of Florida and began to prepare a paper on the mollusks of the lower Miocene reefs of Florida. W. H. Dall studied Pleistocene fossils from the State and completed, for the National Museum, a report on Pleistocene and recent fossils from Florida. C. W. Cooke prepared a report on the age of islands in Lake Worth for the Commissioner of the General Land Office. W. C. Mansfield began the preparation of a preliminary report on Pliocene and Pleistocene fossils from the Florida Everglades. J. T. Pardee is preparing reports on the classification of phosphate lands in Florida.

GEORGIA

Field work.-C. W. Cooke and Laurence LaForge made field studies of the physiographic features of Georgia. 
Office work.-C. W. Cooke and Laurence LaForge began work on a cooperative report on the physiography of Georgia. Julia Gardner began to prepare a paper on the lower Miocene mollusks of Georgia and Florida.

IDAHO

Field work.-G. R. Mansfield, assisted at times by W. B. Lang, completed the geologic mapping and study of the phosphate deposits of the Portneuf quadrangle and of part of the Paradise Valley quadrangle, Idaho. Mr. Mansfield, accompanied by H. T. Stearns, also reviewed the Island Park irrigation project and the Empire irrigation district. At the request of the State Bureau of Mines and Geology Mr. Mansfield visited Moscow for conference on the geology of southeastern Idaho. In cooperation with the State Bureau of Mines C. P. Ross brought up to date the field work in the Hailey quadrangle. He also examined copper deposits near Salmon. E. F. Burchard inspected some iron-bearing mineral deposits in northern Idaho. F. C. Schrader examined molybdenite deposits at Rocky Bar.

Office work.-F. C. Calkins is preparing a report on the dam sites of the King Hill project. Edward Sampson and J. L. Gillson are writing a report on the geology of ore deposits near Lake Pend Oreille in cooperation with the State. A report by J. P. Buwalda on the oil and gas possibilities of southwestern Idaho was submitted to the Idaho Bureau of Mines and Geology for publication. T. W. Stanton, Edwin Kirk, G. H. Girty, and W. H. Dall prepared reports on Cambrian, Silurian, Jurassic, Ordovician, and Carboniferous fossils of Idaho. L. G. Westgate and C. P. Ross made progress on a cooperative report on the Hailey quadrangle. C. P. Ross submitted a report on the copper deposits near Salmon and prepared for unofficial publication a summary of the report. G. R. Mansfield prepared a paper on Tertiary planation in Idaho for publication in the Journal of Geology and a paper on the geography of southeastern Idaho for publication in the Annals of the Association of American Geographers. Mr. Mansfield made progress on reports on the Portneuf and Paradise Valley quadrangles. F. C. Schrader completed a paper on molybdenite in the Rocky Bar district (Bulletin 750-F). P. V. Roundy studied material from outcrops in the State in connection with his work in micropaleontology. J. T. Pardee, Kirk Bryan, and F. H. Knowlton prepared a paper on the relations of the Latah formation to the lavas of the Columbia Plateau. W. H. Dall continued the revision of a report on the remarkable fauna of the Idaho formation (Professional Paper 132-G).

\section{ILLINOIS}

Field work.-Frank Leverett studied glacial drift and glacial filling of the Missisippi River valley in western Illinois.

office work.-G. H. Girty studied Carboniferous fossils from the State. Frank Leverett wrote a paper on glacial studies in western Illinois for presentation at a meeting of the American Association for the Advancement of Science.

Publication.--Geologic Folio 216.

\section{INDIANA}

Frank Leverett began studies of older glacial drift in southern Indiana and Ohio and carried on office work in connection with these studies.

IOWA

Field work.-W. C. Alden made brief examinations of glacial deposits of western Iowa in company with Dr, G. F. Kay, State geologist.

Office work.-G. H. Girty studied Carboniferous fossils from Iowa and revised a report on the typical Kinderhook fauna.

\section{KANSAS}

Field work.-W. W. Rubey, M. N. Bramlette, and N. W. Bass studied the geologic structure in parts of Kansas in cooperation with the State in a search for oil and gas, mapping Russell County and parts of northeastern Ellis County and southwestern Osborne County. 
Office work.-W. W. Rubey and R. C. Moore identified microscopic fossils in well cuttings. G. H. Girty studied collections of Carboniferous fossils. T. W. Stanton reported on Cretaceous fossils. Frank Leverett wrote a paper on glacial deposits in Kansas for the American Association for the Advancement of Science. K. C. Heald prepared a paper on the stratigraphy of western Kansas for the American Association of Petroleum Geologists. W. W. Rubey and N. W. Bass completed a report on the oil and gas resources of Russell County. M. N. Bramlette worked on subsurface correlations in west-central Kansas.

\section{KENTUCKY}

Field work.-Charles Butts examined a proposed addition to a national forest in eastern Kentucky for the Forest Service and investigated the relation of the Sample sandstone of Breckenridge to the Bethel sandstone of western Kentucky and southern Illinois.

Office work.-Charles Butts prepared a report on Cumberland County for the State Geological Survey. G. H. Girty studied collections of Carboniferous fossils. M. N. Bramlette and K. C. Heald examined drill cuttings from a deep well near Bowling Green that indicate possible oil production from Ordovician rocks.

\section{LOUISIANA}

Field work.-M. I. Goldman collected specimens and data in Louisiana for his study of salt-dome cap rocks. Sait domes were visited by W. C. Mendenhall, David White, W. T. Thom, jr., and K. C. Heald.

office work.-M. I. Goldman continued the study of salt-dome cap rocks and prepared a paper on their petrography for the American Association of Petroleum Geologists. E. W. Berry and Julia Gardner reported on fossil plants. M. N. Bramlette wrote a paper on bentonite in the Upper Cretaceous of Louisiana, to be read before and published by the American Association of Petroleum Geologists, and studied well samples. He also prepared a paper on the occurrence of volcanic rocks in the Cretaceous beds of Louisiana, for publication in the Bulletin of the American Association of Petroleum Geologists.

\section{MAINE}

Laurence LaForge examined the Portland quadrangle, Maine, in connection with his office work in the preparation of the Portland folio. J. S. Diller studied postglacial faulting in the Sunday River, White Cap, and Ice Cave mountains.

\section{MARYLAND}

Field work.-Work in Carroll and Frederick counties, Md., was carried on by A. I. Jonas and in Harford County by E. B. Knopf and Miss Jonas.

Office work.-A. I. Jonas continued work on a report on Carroll County for the Maryland Geological Survey and prepared a paper on the pre-Cambrian beds of the southwestern Piedmont region of Maryland for presentation at a meeting of the Geological Society of America. E. B. Knopf began a cooperative report on Harford County and prepared a paper on the physiography of eastern Pennisylvania and Maryland. W. C. Mansfield studied Pleistocene invertebrate fossils from Wailes Bluff.

\section{MASSACHUSETTS}

Laurence LaForge did supplemental field work near Boston in connection with the Boston folio, which is practically completed. L. M. Prindle continued office work on the Taconic folio.

\section{MICHIGAN}

Field work.-Frank Leverett, in cooperation with the Michigan Geological Survey, completed the map of the Port Huron morainic system in Arenac, Iosco, and Ogemaw counties and was engaged in a cooperative study of the glacial deposits in Antrim County. He also completed cooperative field mapping of the Marshall quadrangle. E. O. Ulrich, in company with members of the Michigan Geological Survey, made a reconnaissance study of the Ordovi- 
cian and Silurian formations of northern Michigan. B. S. Butler, assisted by W. S. Burbank, made studies in the Michigan copper district.

office work.-Frank Leverett prepared a report on the surficial geology of Antrim and Ogemaw counties for the Michigan Geological Survey. E. O. Ulrich studied Ordovician and Silurian fossils collected in northern Michigan and compared faunas from the Collingwood and Maquoketa black shales.

\section{MINNESOTA}

E. F. Burchard held conferences with geologists and mining engineers at Minneapolis. Frank Leverett worked on a report on the Quaternary geology of Minnesota and bordering districts.

\section{MISSISSIPPI}

Field and office work.-E. F. Burchard examined the bauxite area of northeastern Mississippi and prepared a report on it (Bulletin $750-\mathrm{G}$ ). M. N. Bramlette made a microscopic study of samples of rock from wells in northeastern Mississippi and wrote a paper describing and correlating formations drilled through in two wells in the Paleozoic beds of northern Mississippi.

Publication.-Professional Paper 133.

\section{MISSOURI}

Field work--E. O. Ulrich, assisted by R. D. Mesler, in association with members of the Missouri Geological Survey, examined the stratigraphy in southern Missouri. Frank Leverett studied the borders of the Mississippi Valley to determine the relations of the several glacial formations to drainage in the ice age and considered other related problems.

Office work.-C. E. Siebenthal continued the preparation of a report on the lead and zinc deposits of the Wyandotte quadrangle, Missouri-Oklahoma. Frank Leverett prepared a paper on glacial studies in Missouri for presentation at the meeting of the Geological Society of America. M. N. Bramlette made microscopic examination of well cuttings from Missouri. R. D. Mesler studied fossils from the Eminence and Forsyth quadrangles. G. H. Girty studied Carboniferous fossils and continued a report on the Pennsylvanian beds of the Joplin district.

MONTANA

Field work.-J. T. Pardee mapped glacial drift in Blackfoot, Jocko, and Flathead valleys, Mont., reexamined the Melrose phosphate field and some adjacent territory, and examined the Morrison potash claim for land classification. C. E. Dobbin and N. W. Bass completed an examination of the Forsyth coal field. A. J. Collier examined Devonian rocks in the Little Rocky Mountains that may be a primary source of oil in northern Montana, and, with R. G. Lusk, completed work southeast of the Sweetgrass region. W. T. Thom, jr., examined the Taylor Fork coal field and, with C. E. Dobbin, studied the Lance and Fort Union formations in eastern Montana and western North Dakota. S. H. Catheart began work in the Jardine district. J. B. Reeside, jr., and C. E. Dobbin studied the stratigraphy between Billings and Forsyth. N. W. Bass mapped part of the Tongue River coal field for land classification. A. A. Baker, assisted by John B. Stone, continued an examination of the Tongue River coal field. W. T. Lee extended into the Big Horn Basin his work on the correlation of Mesozoic formations of Wyoming. Frank Reeves and W. S. Burbank studied the Bearpaw Mountains. In June Sidney Paige visited this party.

Office work.-A report on the northern Big Horn district by G. F. Moulton was transmitted for publication. A revised report on the Tullock Creek coal field (Bulletin 749) by G. S. Rogers and Wallace Lee was transmitted for publication. W. T. Thom, jr., prepared a report on coal in the vicinity of Taylor Fork (Madison Range) for land classification, continued work on reports on the Judith River and Poplar coal fields and the coal lands in the Crow Indian Reservation, and prepared a press notice on the discovery of oil in Lake Basin. K. C. Heald and W. C. Mendenhall prepared a memorandum to the Commissioner of Indian Affairs on the adequacy of test wells drilled on the Milk River anticline, in the Blackfeet Reservation. W. C. Alden continued work on the Cenozoic history of eastern Montana and wrote papers 
on this subject and on the physiographic development of the Great Plains for presentation at the meeting of the Geological Society of America. He also prepared a popular geologic story of the great overthrust in Glacier National Park for outside publication. W. T. Thom, jr., assisted by A. A. Baker, revised and submitted for publication a report by C. M. Bauer on the Ekalaka lignite field (Bulletin 751-F). M. I. Goldman studied phosphate from the Ryan-Stephenson well. K. C. Heald was engaged in preparing a report on the Ingomar dome and prepared a paper for the Great Falls Leader on the Geological Survey and the Montana oil fields. W. T. Lee presented before the Society of Economic Geologists a paper on the continuity of some oilbearing sands in Montana and Wyoming. N. W. Bass prepared a press notice on coal in the Tongue River valley. J. T. Pardee prepared a map of the glacial drift and associated deposits in the Jocko and Flathead valleys and a map, for exhibition before the Geological Society of America, showing the glacial and physiographic geology of the northern Rocky Mountains, and began the preparation of a report on glaciation and gold-bearing gravels in the Pioneer district. He also prepared a report on the Morrison potash claim, near Whitehall, Mont., for land classification and completed a report on the geology of the Melrose phosphate field (Bulletin 750-H). A. J. Collier began work on a report on the geology and oil resources of the Sweetgrass arch and submitted for publication a report on the Scobey lignite field (Bulletin 751-E). G. H. Girty, T. W. Stanton, Edwin Kirk, and J. B. Reeside, jr., examined and reported on Carboniferous, Devonian, Jurassic, and Cretaceous fossils. C. E. Dobbin and N. W. Bass completed a report on the Forsyth coal field for land classification, and Mr. Dobbin prepared a press notice covering coal lands along the projected Armells Creek branch of the Northern Pacific Railway. W. T. Thom, jr., and C. E. Dobbin prepared a paper on the stratigraphy of the Cretaceous-Eocene transition beds in eastern Montana, for presentation at a meeting of the Geological Society of America. Frank Reeves prepared a report on the oil and gas resources of the faulted area south of the Bearpaw Mountains (Bulletin 751-C) and prepared for the Geological Society of America a paper on the structure of the Bearpaw Mountains. B. C. Renick prepared a paper entitled "Some problems of ground water and associated natural gas."

Publications,-Professional Paper 132-B ; Bulletin 749; press notices, "New oil field in Lake Basin, Mont., indicates artesian control of oil and gas accumulation" (No. 17340) ; "Oil and gas prospects north of the Pryor Mountains, Mont." by G. F. Moulton (No. 16001) ; "Coal in Tongue River valley, Mont." (No. 16748) ; "The Rosebud coal bed south of Forsyth, Mont." (No. 16925).

NEBRASKA

J. A. Douglas examined microscopically drill cuttings from a deep well near Lakeside.

NEVADA

Field work.-T. W. Stanton studied the Mesozoic stratigraphy of the Spring Mountain Range, in the Las Vegas quadrangle. L. G. Westgate, assisted by J. L. Gillson, continued a study of the Pioche mining district. H. G. Ferguson and S. H. Cathcart continued the mapping of the Tonopah and Hawthorne quadrangles, in which T. W. Stanton reviewed the marine Triassic and Lower Jurassic sections.

office work.-D. F. Hewett began the preparation of a report on the Goodsprings mining district and wrote a paper on dolomitization near Goodsprings for the Geological Society of Washington. He transmitted for publication a report on magnesia alum near Fallon (Bulletin 750-E). G. H. Girty studied Carboniferous fossils; T. W. Stanton studied Mesozoic, Jurassic, and Triassic fossils; F. H. Knowlton reported on fossil plants near Mina; and Edwin Kirk studied Ordovician, Cambrian, Silurian, and Devonian fossils. H. G. Ferguson and S. H. Cathcart wrote jointly a paper on mountain structure in western Neavda for the Geological Society of Washington and began the preparation of a report on the Hawthorne and Tonopah quadrangles. H. G. Ferguson revised a report on the Manhattan district (Bulletin 723). Adolph Knopf revised a report on the Rochester district (Bulletin 762).

Publication.-Bulletin 723.

NEW HAMPSHIRE

J. S. Diller made glacial studies in the White Mountains and prepared field maps of the White Mountains and vicinity. Arthur Keith continued the preparation of a geographic handbook of New England. 


\section{NEW JERSEY}

W. S. Bayley studied in the field the pre-Cambrian geology of the Delaware Water Gap and Easton quadrangles in connection with studies of magnetite deposits, and began the preparation of a paper on pre-Cambrian geology and ore deposits of these quadrangles.

\section{NEW MEXICO}

F'ield work.-N. H. Darton extended his work in the Red Beds area to supplement the knowledge of the potash-bearing region of New Mexico. J. B. Reeside, jr., mapped the Ute and Barker Creek domes, Southern Ute Indian Reservation, San Juan County, and mapped the Hogback anticline near Shiprock, at the request of the Office of Indian Affairs.

Office work.-T. W. Stanton reported on Upper Cretaceous fossils. G. H. Girty studied Carboniferous fossils. N. H. Darton redrew the contours of the geologic map of New Mexico. K. C. Heald prepared memoranda on the oil resources of the Navajo Reservation for the commissioner of the reservation. J. B. Reeside, jr., revised a manuscript on the Cretaceous and Tertiary formations of the western part of the San Juan Basin, Colorado and New Mexico. He also prepared reports on the Hogback anticline and the Ute and Barker Creek domes, which were transmitted to the Office of Indian Affairs.

Publications.-Bulletins 752, 760-A.

\section{NEW YORK}

Field and office voork.-L. M. Prindle continued field studies of the geology of the Hoosick and Berlin quadrangles, N. Y., and office work on the Taconic geologic folio. W. H. Dall studied two large collections of fossils sent from the Brooklyn museum.

Publication.-Bulletin 744.

\section{NORTH CAROLINA}

Field work.-C. S. Ross revisited the Ore Knob copper mine, in Ashe County, N. C. C. W. Cooke collected Miocene fossils near Jacksonville.

Office work.-E. W. Berry began the preparation of a manuscript on the Pleistocene flora of North Carolina. L. B. Kellum completed a paper on the paleontology and stratigraphy of the Castle, Hayne, and Trent marls of North Carolina.

\section{NORTH DAKOTA}

Field work.-W. T. Thom, jr., and C. E. Dobbin made an extensive reconnaissance through the lignite fields of western North Dakota to discover the relations of the coal-bearing formations.

Office work.-W. T. Thom, jr., assisted by J. B. Eby and A. A. Baker, revised a report by C. J. Hares on the geology and lignitic resources of the Marmarth field, in southwestern North Dakota, and submitted it for publication. W. T. Thom, jr., and C. E. Dobbin completed a paper on the Cretaceous-Eocene transition beds, Dakota-Montana. J. B. Reeside, jr., reported on Cretaceous fossils.

\section{онто}

Frank Leverett began field studies of the older glacial drift in southern Indiana and Ohio. G. H. Girty reported on Carboniferous fossils.

\section{OKLAHOMA}

Field work.-H. D. Miser was engaged in field work required for a geologic map of Oklahoma. A. F. Melcher collected data on the production and texture of producing oil sands in the Tonkawa and Burbank fields. K. C. Heald, at the request of the Commissioner of Indian Affairs, attended the sale of Osage leases at Pawhuska. David White, K. C. Heald, and H. D. Miser participated in a conference at Houston about work on the Oklahoma geologic map and subsurface work in Oklahoma for which the State legislature has made an appropriation.

Office work.-H. D. Miser compiled data for a geologic map of Oklahoma. In response to a request from the Office of Indian Affairs $K$. C. Heald and W. T. Thom, jr., considered the possible yield of oil from 1,328 undrilled oil leases in the Osage Reservation and prepared recommendations regarding them. P. V. Roundy prepared data for use at the sale of Osage leases at Pawhuska and studied outcrop material and well cuttings from Oklahoma. 
A. F. Melcher examined chunk samples of oil and gas sands of the Tonkawa and Burbank districts and prepared a paper on the application of productionporosity curves to the Burbank field for publication in the Bulletin of the American Association of Petroleum Geologists. A part of a diamond-drill core from the Tonkawa field is being studied in an attempt to establish a type stratigraphic section for western Oklahoma. G. H. Girty revised his report on the fauna of the Morrow formation of Arkansas and Oklahoma. T. W. Stanton identified Cretaceous invertebrates, G. H. Girty studied Carboniferous fossils, W. H. Dall reported on Pleistocene fossils, and E. O. Ulrich prepared reports on the Stanley, Jackfork, and Caney formations and reported on fossils from a deep well in Oklahoma. G. H. Girty and P. V. Roundy worked on a report on the Moorefield fauna of northeastern Oklahoma. O. E. Siebenthal is preparing a report on the lead and zine deposits of the Wyandotte quadrangle, Missouri-Oklahoma.

Publication:-Bulletin 751-B.

OREGON

Field work.-W. H. Bradley examined the deposits in Goose Lake and Upper Klamath Lake in a study of the origin of oil shale.

Office work. - C. P. Ross revised a report on the Wallowa Mountains. F. C. Calkins continued the preparation of a report on dam sites in Idaho and Oregon for the Bureau of Reclamation. W. S. W. Kew prepared a report on the occurrence of oil shale near Medford, a copy of which was sent to the Oregon Corporation Commission.

Publication.-Geologic Folio 218.

\section{PENNSYLVANIA}

Field work.-Field conferences were held in Pennsylvania by Sidney Paige, Adolph and E. B. Knopf, and Florence Bascom relative to mapping the Quarryville and McCalls Ferry quadrangles and adjoining areas. Mrs. Knopf studied the pre-Cambrian rocks of Pennsylvania near Coatesville and Oxford. A. F. Melcher inspected pressure apparatus at the University of Pittsburgh and visited the Bradford oil field. G. W. Stose worked in the Lancaster, New Holland, Coatesville, Honeybrook, Phoenixville, and Doylestown quadrangles. W. S. Bayley worked in the Easton and Delaware Water Gap quadrangles in a study of the pre-Cambrian magnetite-bearing rocks. David White, with 0 . C. Postley and A. M. Farrell, studied the stratigraphy of the Brookville coal in the vicinity of the type locality. W. C. Mendenhall, with other members of the Survey, made a trip through central and southern Pennsylvania and southwestern New England to obtain a general idea of the geologic succession.

Office work.-E. B. Knopf and A. I. Jonas continued work on a report on the Quarryville and McCalls Ferry quadrangles, and Miss Jonas began the preparation of a report on the Lancaster and New Holland quadrangles. Mrs. Knopf presented before the Geological Society of America a paper on the physiography of eastern Pennsylvania and Maryland. W. S. Bayley began the preparation of a paper on the pre-Cambrian geology and ore deposits of the Easton and Delaware Water Gap quadrangles. G. H. Girty studied Carboniferous fossils, E. O. Ulrich reported on fossils of Trenton age, and Edwin Kirk reported on Devonian fossils. G. W. Stose completed and transmitted to the State geologist a report on the economic geology of Adams County. He also prepared and read before the Geological Society of America a paper on a new type of structure in the Pennsylvania Appalachians. Charles Butts prepared papers on the Loyalhanna limestone in southwestern Pennsylvania and on the Birmingham overthrust fault in the Lynne quadrangle for the Geological Society of America. He also prepared a map of a small part of the Standingstone quadrangle for R. S. Bassler.

\section{SOUTH CAROLINA}

Field work.-G. R. Mansfield studied parts of the phosphate field of South Carolina.

Office work.-J. B. Reeside, jr., read proof of a paper on a new Eocene nautiloid from South Carolina, to be published as No. 2518 of the Proceedings of the United States National Museum.

\section{SOUTH DAKOTA}

Office work.-T. W. Stanton reported on Upper Cretaceous fossils from South Dakota for the State geologist. J. B. Reeside, jr., reported on Cretaceous 
fossils collected by C. E. Dobbin in western South Dakota and studied Jurassic fossils collected near Rapid City by W. T. Lee. G. H. Girty reported on some Carboniferous fossils. W. T. Thom, jr., prepared a joint paper with C. E, Dobbin on the Cretaceous-Eocene transition beds in the Dakotas and Montana. N. H. Darton spent some time condensing the text of the Black Hills folio.

\section{TENNESSEF}

Field work.-E. O. Ulrich, assisted by R. D. Mesler, studied the stratigraphy of the Tellico formation in eastern Tennessee. E. F. Burchard continued studies of brown iron ores in west-middle Tennessee in cooperation with the Tennessee Geological Survey. Charles Butts reviewed the geologic mapping of a part of the Friendsville marble belt.

Office work.-T. W. Stanton revised Bruce Wade's manuscript on the Upper Cretaceous fauna of Coon Creek (Prof. Paper 137). E. O. Ulrich, assisted by R. D. Mesler, prepared and compared old and new collections of fossils from beds of marble in eastern Tennessee in order to settle a controversy regarding the identification of the Meadow marble and to correct the mapping of its boundaries. In preparing a paper on additions to the flora of the Wilcox group, E. W. Berry studied material from this group in Tennessee. He also reported on Eocene plants from Tennessee. G. H. Girty studied Carboniferous fossils. E. F. Burchard began the preparation of a cooperative bulletin on the brown iron ores of west-middle Tennessee. D. F. Hewett continued the preparation of a paper entitled "Relation of manganese oxides in Virginia and Tennessee." Charles Butts revised the geologic map and profile sections of the Friendsville marble area.

TEXAS

Field work.-W. B. Lang visited wells in the western Texas potash area and procured samples of rock borings. Julia Gardner continued the study of the lower Eocene formations of the State. M. I. Goldman collected specimens and data for a study of the salt-dome cap rocks in the Gulf coast region of Texas and Louisiana. K. C. Heald held a field conference with Receiver Delano at Wichita Falls.

Office work. - In conjunction with the Director of the Survey, G. R. Mansfield prepared for the Journal of the American Bankers' Association an article entitled "Potash-the key to prosperous agriculture." Mr. Mansfield investigated the cost of core drilling in Texas in response to a request from Senator Sheppard for an estimate of the ámount required to make tests of cores of wells drilled for potash in western Texas and with W. B. Lang attended hearings on Senator Sheppard's potash bill before the Senate Committee on Agriculture and the House Committee on Mines and Mining. In connection with the search for potash W. B. Lang conferred with members of the Survey and the Bureau of Mines, compiled field data, and drafted maps of an area in Texas A press notice on potash in western Texas was prepared by David White and George Steiger. Work on salt-dome cap rocks was continued by M. I. Goldman, who prepared a paper entitled "The petrography of salt-dome cap rocks," for presentation at the Houston meeting of the American Association of Petroleum Geologists. G. H. Girty, P. V. Roundy, and M. I. Goldman prepared a paper on the microfauna of the Mississippian formations of San Saba County, Tex., which includes a study of the age and correlation of the Ellenburger and Mississippian limestone contact. G. H. Girty worked on a report on the basal Bend fauna of Texas, which he is preparing with P. V. Roundy, and studied Carboniferous fossils from the State. E. W. Berry continued the study of fossil plants in connection with his manuscript on additions to the Wilcox flora and studied collections of fossil plants from the State. Julia Gardner preparerl a report on the fossiliferous marine Wilcox beds of Texas for outside publication and continued work on her report on the Eocene formations of Texas. Miss Gardner studied Texas fossils in the Aldrich collection at Johns Hopkins University, Baltimore, Md., and made determinations of small collections from the Butler dome in Anderson County. L. W. Stephenson continued work on his paper entitled "Summary of the stratigraphy of the Gulf series (Upper Cretaceous) formations of Texas between Austin and the Rio Grande." E. O. Ulrich determined the horizons of fossils in a deep well in Texas; $T$. W. Stanton reported on Comanche fossils; W. H. Dall reported on fossils from the State; and P. V. Roundy examined outcrop material and drill cuttings. K. C. Heald prepared a statement regarding the oil, gas, and coal resources of southwestern Texas for the Interstate Commerce Commission and, with David 
White, attended hearings on the West Columbia salt dome before the incometax division of the Treasury Department.

Publications.-Professional Papers 126, 132-D; press notice on potash in western Texas (No. 16953).

UTAH

Field work.-F. L. Hess revisited carnotite fields in Utah and, with V. C. Heikes, examined arsenic and tungsten deposits in the Clifton district. G. I. Finlay and Carle $\mathrm{H}$. Dane made a reconnaissance map of an area along Gypsum Creek. E. M. Spieker, assisted by A. A. Baker and later by D. J. Fisher, completed an examination of the Wasatch Plateau coal field and coal-bearing areas in Salina Canyon and near Horse Canyon and Crescent.

office work.-E. M. Spieker and A. A. Baker continued the preparation of a report on the Wasatch Plateau coal field and transmitted for publication reports on coal in the Salina Canyon, near Horse Canyon, and near Crescent, Utah. Messrs. Spieker and Baker prepared reports for classification of lands. G. H. Girty began the preparation of a report on the Triassic faunas of Utah. H. D. Miser prepared a popular article on the exploration of the San Juan Canyon, a tributary of the Colorado, by K. W. Trimble and himself. He also completed a report on anticlinal structure in San Juan County (Bulletin 751-D). J. B. Reeside, jr., prepared the first draft of a popular report on the geology of Green River valley, Wyoming, Colorado, and Utah, for inclusion in a paper by $R$. R. Woolley on power sites. He also completed an examination of Mesozoic and Tertiary fossils collected by E. M. Spieker in central Utah. F. H. Knowlton reported on material from the Mesaverde formation of Utah for Mr. Spieker. F. R. Clark completed and transmitted for publication a report on the Sunnyside, Wellington, and Castlegate quadrangles. F. C. Calkins continued the preparation of a report on the general geology of the Cottonwood district by B. S. Butler and himself.

Publications.-Professional Paper 132-C, Bulletin 750-A.

\section{VERMONT}

L. M. Prindle spent some time in field work on the geology of the Taconic quadrangle and in the office continued the preparation of the Taconic folio.

\section{VIRGINIA}

Field work.-M. R. Campbell, assited at times by W. T. Thom, jr., completed a study of the Valley coal fields of Virginia, made in cooperation with the Virginia Geological Survey. E. O. Ulrich and R. D. Mesler studied the stratigraphy of areas in southwestern Virginia. W. C. Mansfield studied Tertiary deposits along James River above and below Claremont and in the "Northern Neck," mainly north of Warsaw.

Office work.-M. R. Campbell worked on a cooperative report on the Valley coal fields of Virginia. He also prepared a press notice on these fields. W. C. Mansfield continued the preparation of a report on the Miocene stratigraphy of Virginia. E. O. Ulrich began work on the faunas of the Murat limestone of Virginia, undertaken particularly to determine the age of the Holston marble of Tennessee. Mr. Mesler worked on collections of Ordovician fossils. G. W. Stose prepared a paper on iron carbonate in Clinton ores of southwestern Virginia for publication in Economic Geology and one entitled "The black-shale problem of Virginia." He also read proof of a report on Wise County to be published by the Virginia Geological Survey. Charles Butts reported on samples of well borings from the Rose Hill well. Edwin Kirk reported on Devonian fossils. K. C. Heald wrote a paper on Lee County for outs de publication. D. F. Hewett prepared a paper entitled "Relation of manganese oxide in Virginia and Tennessee."

Publications.-Press notices on the Valley coal fields of Virginia and oil in Lee County, Va.

\section{WASHINGTON}

Field work.-E. F. Burchard conferred with geologists and mining engineers in Spokane and examined iron-bearing deposits in northern Washington. J. T. Pardee studied Miocene shale and associated rocks for a report being prepared by him, F. H. Knowlton, and others.

Office work.-F. H. Knowlton studied the flora of the Puget group of Washington and described new fossil plants for a paper on the age of strata inter- 
bedded with the Columb:a lava at Spokane, Wash., and Coeur d'Alene, Idaho, and J. T. Pardee prepared an introduction to this paper. W. H. Dall reported on collections of Pleistocene invertebrate fossils. T. W. Stanton studied Lower Cretaceous invertebrate fossils from northwestern Washington.

\section{WEST VIRGINIA}

Field work.-By invitation of the State geologist, David White joined a party from the West Virginia Geological Survey early in May for a reconnaissance examination of the Mississippian formations in several counties of the State south of the Chesapeake \& Ohio Railway. Fossil plants were collected from horizons representing the Pocono, Greenbrier, and Mauch Chunk divisions. The expense of the trip was borne by the State Survey, which is preparing, in cooperation with the Federal Survey, a comprehensive report on the stratigraphy, areal geology, and paleontology of the Mississippian formations in the southern half of the State. The invertebrate fossils collected will be described by G. H. Girty and the plants by David White.

Office work.-G. H. Girty studied Carboniferous collections from West Virginia.

\section{WISCONSIN}

Field work.-E. O. Ulrich studied the Paleozoic stratigraphy of Wisconsin and conferred with the State geologist.

Office work.-E. O. Ulrich studied Ordovician and Silurian fossils from Wisconsin and prepared collections of Wisconsin Cambrian fossils for study. Frank Leverett worked on reports in hand.

\section{WYOMING}

Field work.-J. B. Reeside, jr., and C. E. Dobbin made stratigraphic and structural studies of the Powder River basin, Wyo., giving particular attention to the Fox Hills formation and its relations to the Pierre shale and the Lance formation. They made reconnaissance trips near Baggs, Rawlins, Walcott, and Lander and in the Big Horn Basin. Edwin Kirk studied the Rocky Mountain Ordovician rocks. F. L. Hess and C. W. Henderson visited reported platinum and placer gold deposits in the Medicine Bow Mountains. W. C. Alden studied the glacial deposits and the physiography in Park, Big Horn, Hot Springs, Washakie, Natrona, Johnson, Sheridan, and Fremont counties. W. T. Lee worked between Thermopolis, Wyo., and Bridger, Mont., in a study of oil-bearing formations. J. D. Sears, assisted by P. C. Benedict and Quentin Singewald, examined coal lands on Vermilion Creek, in southern Baxter Basin, Sweetwater County, for land classification and did some work in the Baxter Basin gas field. John D. Northrop examined tracts in the Arminto coal field and in the southern Big Horn Basin coal field for land classification. W. $H$. Bradley, assisted by Carle H. Dane, mapped and studied oil shales of northern Sweetwater County. A. J. Collier, C. D. Ayery, and E. T. McKnight mapped anticlines in southern Wyoming. W. H. Bradley and C. E. Erdmann made a three-day reconnaissance northwest of Rock Springs. J. B. Eby worked in the Yampa coal field and examined the stratigraphy and structure of parts of northwestern Colorado and southern Wyoming with J. B. Reeside, jr., and C. E. Dobbin. At the request of the Bureau of Mines W. T. Thom, jr., examined coal lands in the vicinity of Gillette. N. W. Bass and W. T. Thom, jr., examined miscellaneous tracts covered by applications for prospecting permits. C. D. Avery collected information about oil wells at Casper, Glenrock, Douglas, Torrington, Guernsey, Cheyenne, Laramie, Rawlins, and Medicine Bow. W. W. Rubey, assisted part of the time by H. W. Hoots, Alexander Stepanoff, M. N. Bramlette, and F. A. Melton, continued studies in several areas on the Black Hills rim.

Office work.-W. T. Thom, jr., prepared a report for the Bureau of Mines on coal lands near Gillette. W. T. Thom, jr., J. D. Sears, J. D. Northrop, and N. W. Bass reported on tracts examined for land classification. F. H. Knowlton reported on fossil plants from central Wyoming and studied fossil plants from the Rock Springs coal group of Wyoming. W. C. Alden prepared a paper on the physiographic development of the northern Great Plains for the Geological Society of America. A. J. Collier wrote a press notice on oil and gas prospects of the North Casper Creek anticline, and K. C. Heald prepared a memorandum concerning its possibilities as a naval oil reserve. W. W. Rubey compiled data relative to the Dry Creek anticline for land classification. P. V. Roundy worked with K. C. Heald on maps of the Teapot dome and studied out- 
crop material. G. H. Girty studied Carboniferous fossils. J. D. Sears revised his report on the geology and oil and gas prospects in a part of Moffat County, Colo., and southern Sweetwater County, Wyo. (Bulletin 751-G). D. F. Hewett completed the report on the geology and the oil, gas, and coal resources of the Oregon Basin, Meeteetse, and Grass Creek Basin quadrangles. A press notice on the possible oil in deep sands near the Osage field in Wyoming, including a structure contour map and description of the Pump Creek anticline, was prepared by C. R. Longwell and W. W. Rubey. K. C. Heald studied well cuttings from a deep well near the Osage field and from a deep well in Goshen Hole. W. C. Alden continued the preparation of a report on the Cenozoic history of eastern Montana and Wyoming, which includes an account of the Tertiary and Pleistocene bench gravels and glacial phenomena. W. T. Lee prepared a report on the continuity of some of the oil-bearing sands of Wyoming and Montana for presentation before the Society of Economic Geologists. J. B. Reeside, jr., prepared a popular report on the geology of the Green River valley, in Wyoming, Colorado, and Utah, for inclusion in a paper by $\mathbf{R}$. R. Woolley on power sites. K. C. Heald outlined a research problem for Edwin Binney, of Yale University, and started him on his work, which involves a study of the occurrence of gas in the Oregon Basin and Garland domes. J. D. Sears began the preparation of a report on the Baxter Basin gas field and submitted a preliminary report on the productive area of the field for land classification. W. W. Rubey prepared a report on the Osage, Mooreroft, and Wakeman region for land classification. He also compiled data relative to the Dry Creek anticline for land classification. Work on a report on the Black Hills rim was advanced by W. W. Rubey, H. W. Hoots, and Alexander Stepanoff. W. H. Bradley prepared a paper on fossil caddis-fly cases from the Green River formation of Wyoming for outside publication; also a paper on an oil shale and its microorganisms from the Fuson formation of Wyoming. He also began the preparation of a report entitled "A stratigraphic study of a shore phase of the Green River formation in northwestern Sweetwater County, Wyo." Mr. Bradley also wrote a paper on the calcareous alga reefs of the Green River formation for outside publication. K. C. Heald studied critically the relation of oil and gas to the structure of the Teapot dome and advised Government counsel dealing with this naval reserve. He conferred with Commissioner Stewart in Casper and Cheyenne regarding Naval Reserve No. 3. K. C. Heald, G. W. Stose, and T. W. Stanton completed the compilation of a geologic map of Wyoming. The character and the distribution of the Frontier formation were studied by G. K. Drach and K. C. Heald. J. B. Reeside, jr., reported on Cretaceous and Jurassic fossils from the western rim of the Black Hills and other places. Edwin Kirk reported on Cambrian fossils from Wyoming.

Publications.-Professional Paper 132-C; press notices on the possibility of finding oil in deep sands near the Osage field and the North Casper Creek anticline-a possible new gas and oil field.

\section{ALASKA}

In cooperation with the Alaskan mineral resources branch, F. H. Knowlton and W. H. Dall reported on fossil plants and invertebrate fossils from northern Alaska. Edwin Kirk prepared a paper on Harpidium, a new genus of pentameroid brachiopods from the Silurian rocks of southeastern Alaska. Messrs. Roundy, Stanton, Kirk, Girty, Knowlton, and Reeside reported on Carboniferous, Mesozoic, Paleozoic, Ordovician, Silurian, Devonian, Jurassic, and Cretaceous fossils.

CANADA

P. V. Roundy studied Ostracoda from Canada. G. H. Girty worked on Carboniferous fossils. Edwin Kirk prepared a manuscript on the stratigraphy of the Beaverfoot, Brisco, and Stanford ranges, British Columbia. Julia Gardner worked on a report on the gastropods of the Mons formation and prepared reports and revised manuscripts on the Paleozoic fauna of British Columbia for Secretary Walcott of the Smithsonian Institution. T. W. Stanton prepared a report on some Upper Cretaceous fossils from Alberta. W. H. Dall read proof of a short report to the Canadian Government on Oligocene material from the Arctic coast. F. L. Hess examined nickel and other mines in Canada at his own expense. Edwin Kirk was detailed to work with Secretary Walcott on the Upper Paleozoic fauna of British Columbia. W. H. Dall reported on fossils sent in by the Provincial Museum, Victoria, British Columbia. 


\section{WEST INDIES}

W. H. Dall reported on fossils from the Bahama Islands and from Bermuda. W. C. Mansfield identified Eocene and later fossils from Jamaica and prepared for publication a report on Miocene gastropods from Trinidad. W. P. Woodring prepared a report on Jamaican fossils for Dr. C. A. Matley, Government geologist of Jamaica, and helped in the publication and distribution of a report on the geology of the Republic of Haiti.

\section{MEXICO AND CENTRAL AMERICA}

Iulia Gardner examined fossils from Mexico. C. W. Cooke cataloged types of Mexican fossils. W. H. Dall furnished information on fossils from Lower California to Eric Jordan. J. B. Reeside, jr., examined Cretaceous fossils collected in Tehuantepec by J. T. Singewald. T. W. Stanton identified invertebrates of Comanche age from Guatemala. W. H. Dall reported on a small lot of Miocene fossils for W. C. Mansfield, who made a preliminary report on Oligocene and later fossils from Guatemala. W. C. Mansfield prepared a report on fossils from the Province of Chiriqui, Panama. W. P. Woodring attended to correspondence concerning geologic work in Central America.

\section{SOUTH AMERICA}

W. C. Mansfield prepared preliminary reports on Tertiary and Quaternary fossils from Colombia and Ecuador. J. B. Reeside, jr., examined collections of Mesozoic fossils from Colombia and examined and identified Cretaceous and Tertiary fossils from Patagonia. W. H. Dall reported on fossils from Peru, Venezuela, Brazil, Uruguay, and Patagonia.

\section{AUSTRALIA AND PACIFIC ISLANDS}

T. W. Vaughan, A. H. Brooks, and H. E. Gregory attended conferences of the Pan-Pacific Science Congress at Melbourne and Sydney, Australia, and made some geologic examinations. T. W. Vaughan visited museums and inspected Tertiary formations in New Zealand. W. H. Dall reported on fossils from Palmyra Island for the Bishop Museum at Honolulu and on fossils from the Fiji Islands. W. C. Mansfield prepared a report on fossils from Vavao, Tonga Islands, revised his manuscript on the Tertiary fossils of the Fiji Islands, and prepared a report on fossils from quarries near Suva, Viti Levu, and an annotated bibliography on the geology of the Fiji Islands. W. H. Dall reported on Hawaiian fossils and prepared illustrations for a monograph on Hawaii. W. C. Mansfield made a generic list of Miocene and later fossils collected by E. F. Burchard in the Philippine Islands.

\section{ASIA}

G. H. Girty worked on Carboniferous fossils from China. W. H. Dall reported on fossils from China for Prof. Arthur Jacot, Hau Liu University. F. H. Knowlton studied and prepared a report on fossil plants from central China. T. W. Stanton studied Chinese Mesozoic invertebrates. W. H. Dall reported on fossils from Japan and from the Persian Gulf.

\section{EUROPE}

W. H. Dall reported on fossils sent in by Dr. N. H. Odhner, of the Royal Academy, Stockholm, Sweden, on fossils from Shrewsbury, England, and on Pliocene fossils from Iceland.

\section{DIVISION OF MINERAL RESOURCES}

The work of the division of mineral resources was carried on during the year with little change in organization or program. On May 23, 1924, G. F. Loughlin, geologist in charge, was relieved of duty as chief of the division in order to assume charge of the section of metalliferous deposits in the division of geology, and Frank J. Katz was appointed geologist in charge. On November 11, 1923, the division suffered the loss of one technical employee through the resignation of $\mathrm{H}$. A. C. Jenison, specialist on copper and manganese. F. G. Tryon, who had been transferred 
to the United States Coal Commission during the preceding year, was reinstated in the division on September 23, 1923, and was furloughed on June 24, 1924, for about two months, to permit him to make special studies in Europe under the auspices of the Institute of Economics. The clerical staff was reduced by the resignation of one member and the transfer of two to other offices. This reduction was partly offset by the appointment of one clerk, who was assigned to duty at the branch office of the Survey at Denver. During the year the division employed, for short periods, nine clerks on temporary appointments in the Washington office and two on temporary appointments in the branch offices.

The work of the division continued to be hampered by inadequacy of personnel, working space, and funds for field canvasses and other investigations.

Cooperation with the Bureau of the Census in the census of manufactures for 1923 was maintained according to the program laid down for 1921, as outlined in the Director's report for the fiscal year 1922. Joint canvasses under this arrangement were essentially complete at the end of the fiscal year. The division also undertook, for the Bureau of the Census and the Forest Service, a canvass of coal and metal mines to obtain data on the use of timber underground in mines.

Cooperation with State geological surveys was continued. During the year the cooperating States were Alabama, Florida, Georgia, Illinois, Iowa, Maryland, Michigan, Missouri, New Jersey, New York, North Carolina, Oregon, Texas, Virginia, Washington, and Wisconsin.

The metals section limited its work to the routine of collecting and publishing statistical matter relating to the mine, smelter, and refinery output of metals and to performing a small amount of work in cooperation with the Senate Commission on Gold and Silver Inquiry. The nonmetals section also was engaged almost entirely in routine statistical inquiries and compilations, though in cooperation with the division of geology it made some field investigations of cement, bauxite, and asbestos. The coal section, in addition to compiling the annual statistical reports, prepared and issued its regular weekly report on coal and coke, continued to assist the United State Coal Commission up to the date of its termination, maintained contact with the Department of Commerce in its studies of special features of the coal industry, and, in cooperation with the Bureau of the Census, undertook and reported on four canvasses of consumers' stocks of coal. The petroleum and natural gas section, besides performing its routine work in preparing the annual report and monthly statements on petroleum, compiled.certain special statistics for the Federal Trade Commission and completed the preparation of a map showing petroleum and natural gas fields and petroleum pipe lines in Texas. The section of foreign mineral reserves was engaged chiefly in completing a world atlas on fuel reserves and in collecting and compiling information on the production of minerals in foreign countries.

In the San Francisco office the demand for statistical work required all the time of the geologist in charge, J. M. Hill, and necessitated the employment of additional temporary clerical help for 
about two and one-half months. V. C. Heikes, the statistician in charge of the Salt Lake City office, devoted a large part of his time to special studies of the available supply of arsenic and made several field investigations of arsenic resources and arsenic manufacturing plants. In the Denver office, in addition to making the routine statistical inquiries, C. W. Henderson, in charge, completed an exhaustive paper on the history of mining in Colorado (Prof. Paper 138).

Progress in the compilation of the annual chapters and the preparation of the completed volumes of Mineral Resources of the United States was farther advanced at the end of the year than in recent preceding years. Part I of the volume for 1922 is nearly ready for the printer. All the chapters of Part II were published except those on petroleum, coal, and coke, which were in the hands of the printer at the end of the year. Of the chapters for 1923, 25 were transmitted for publication, and 5 of these were published by the end of the year. The preliminary summary of mineral production in 1923 was transmitted April 8 and was in galley proof at the end of the year. Most of the reports for 1923, like those for several years preceding, have been made brief, primarily to keep within the limit imposed by reduced printing funds and partly because the lack of specialists on certain subjects has made impossible the preparation of more than statistical material for publication.

\section{DIVISION OF CHEMICAL AND PHYSICAL RESEARCH}

The personnel of the division of chemical and physical research on July 1, 1923, consisied of 7 chemists, 2 physicists, 2 laboratory aids, 1 clerk, 1 laboratory assistant, and 1 laborer. George Steiger was in charge of the division and supervised the work of the chemical laboratory, and C. E. Van Orstrand supervised the work of the physical laboratory. M. A. Shoultes, laboratory aid, resigned on August 31, and C. R. Randall, junior physicist, was appointed to fill the vacancy on March 1.

\section{WORK IN CHEMISTRY}

For the official work of the Survey 782 quantitative analyses were made and a number of minerals were determined, the determinations including a careful study of their properties. In addition 2,698 specimens sent to the Survey by persons outside were identified. On June 30400 samples were awaiting quantitative analysis and 75 specimens awaiting identification.

The bulletin entitled "The data of geochemistry" was revised and prepared for a fifth edition (Bulletin 770) by its author, F. W. Clarke, by adding facts necessary to bring it up to date.

The chemical and physical properties of a group of uranium and vanadium minerals, chiefly from Utah, Colorado, and Peru, were studied by W. $\mathrm{T}$. Schaller. This study has not only shown the eomposition of these minerals but has furnished data on their age, as well as on the age of the earth. Mr. Schaller also made laboratory experiments to show the relations of minerals of the jarosite group. Recent discoveries of natural silver jarosite (argentojarosite) suggested that gold-platinum-palladium jarosite also exists in nature, and recalculations of analyses of ores from Nevada confirm this suggestion. Mr. Schaller prepared two papers, one for publication in the American Journal of Science on the "Occurrence and properties of sincosite" - and one for the open files of the Geological Survey on the "Occurrence of phlogopite in the United States."

At the conclusion of a series of laboratory experiments made to elucidate the mode of formation of metallic copper in ore deposits $R$. C. Wells made a brief report to L. C. Graton and B. S. Butler, geologists cooperating in 
the study, and later prepared the manuscript for a bulletin entitled "Deposition of native copper by ascending solutions." Mr. Wells also prepared, for the committee on the measurement of geologic time by atomic disintegration, a bibliography of the literature dealing with the relation of radioactivity to geologic problems, which was published by the National Research Council. A note on the Hicks method of determining potassium was prepared for publication by R. C. Wells, R. K. Bailey, and J. G. Fairchild.

A series of laboratory experiments showing the solubility, the permeability, and the disintegrating effects of nitric acid on granites was concluded, and a paper on the results was prepared by George Steiger. Mr. Steiger also wrote a section on the "Chemical and mechanical analysis of sediments" for a treatise on sediments being prepared for publication by Prof. W. H. Twenhofel, of the University of Wisconsin.

The study of the chemical nature of the organic matter in oil shale was continued throughout the year by E. T. Erickson. The object of this study is to discover the source and the mode of formation of petroleum and other natural hydrocarbons, and the information obtained may also be of practical value in the recovery of oil from oil shale. Experiments were made with fish remains taken from a sunken vessel and with a number of samples of sediment from the Bay of Maine. Both investigations afforded data relative to the formation of petroleum from plant and animal material embedded in sediments.

A series of very elaborate assays, necessitating the study and choice of efticient methods for determining extremely small quantities of platinum in rocks reputed to be platinum ores, was made by $\mathrm{Mr}$. Erickson.

E. P. Henderson made 2,698 qualitative determinations of minerals for outside persons. Nearly all the regular routine quantitative analyses were made by J. G. Fairchild.

R. K. Bailey made 662 analyses of potash salts in material from western Texas. A most promising area for deposits of potash is in the southern half of Reagan County, where a potash-rich stratum was indicated at about the 1,300-foot level in each of three wells sunk 800 feet apart. Samples of salts from wells farther east are of the same general character, This is the most encouraging showing of potash yet found.

\section{WORK IN PHYSICS}

The section of physics, in addition to cooperating with the geologists in the study of certain special problems, continued investigations in the fields in which it has heretofore worked.

Observations of deep earth temperatures were made in Oklahoma, Pennsylvania, and Wyoming by C. E. Van Orstrand. A paper on "Apparatus for the measurement of temperatures in deep wells by means of maximum thermometers" was published in Economic Geology. Another paper summarizing the results of a somewhat extended temperature survey in Yellowstone National Park was published in the Journal of Geology under the title "Temperatures in some springs and geysers in Yellowstone National Park."

At the suggestion of G. B. Richardson an attempt was made to develop a method for the empirical representation of petroleum-production curves. A fair degree of accuracy was attained in the representation of the production data for the States of Ohio, Pennsylvania, and West Virginia and for two oil fields - the Kern River field in California and the Batson field in Texas. Manuscript for the fourth edition of Smithsonian Mathematical Tables, Hyperbolic Functions, has been submitted to the Smithsonian Institution for publication.

Investigations pertaining to the pore space of oil and gas sands were continued by A. F. Melcher. A paper on "The texture of oil sands with relation to the production of oil " has been submitted for publication in the Bulletin of the American Association of Petroleum Geologists. Field and laboratory studies of the texture and productivity of oil sands in the Burbank and Tonkawa fields of Oklahoma were continued. A short field trip to Pittsburgh and Bradford, $\mathrm{Pa}$., was made for the purpose of conferring with geologists and oil companies on the texture of the Bradford oil sand. A. M. Boetcher, a student of George Washington University, and Prof. R. H. Johnson, of the University of Pittsburgh, assisted in the work on pore space. The total number of determinations of pore space made during the year was 150 .

C. R. Randall devoted his time to computations and observations in the laboratory. 


\section{ALASKAN MINERAL RESOURCES BRANCH}

\section{PERSONNEL AND EXPENDITURES}

On July 1, 1923, the personnel of the Alaska force consisted of 1 chief Alaskan geologist, 6 geologists, 2 topographers, 1 cadastral engineer, 1 draftsman, and 4 clerks on annual salaries; 1 assistant geologist and 1 junior topographer on monthly salaries; and 2 geologists, 1 assistant geologist, and 1 geologic aid on per diem salaries; and on June 30, 1924, it consisted of 1 chief Alaskan geologist, 7 geologists, 4 topographic engineers, 1 draftsman, and 3 clerks on annual salaries; 1 geologist, 1 junior geologist, and 1 topographic aid on monthly salaries; and 2 associate geologists on per diem salaries.

The funds available for the field season included the current appropriation of $\$ 75,000$ for the investigation of Alaskan mineral resources and an unexpended balance of $\$ 14,100$ from the similar appropriation available until June 30,1923 . These were allotted as follows :

Allotments for salaries and field and office expenses during field seasons of $1923-24$

Professional salaries $\$ 28,887$

Field expenses 28,100

Clerical salaries and other office expenses

6,870

Office of Director

10,992

Reserved for field season of 1924

14, 251

89,100

Approximate allotments to different kinds of surveys and investigations during field seasons of 1923-24

Special investigation of geology and mineral resources

$\$ 10,990$

Geologic reconnaissance surveys

25,130

Topographic reconnaissance surveys

11,600

Map compilation

2,200

Collecting mineral statisties

1,560

Administration of Alaska branch, including clerical salaries and miscellaneous expenses

Office of Director

10,992

Reserved for field season of 1924

14,251

89,100

Approximate geographic distribution of allotments for investigations in Alaska during field seasons of 1923-24

Special investigation of geology and mineral resources_ $\$ 7,085$

Southeastern Alaska

Prince Wiliam Sound

Alaska Railroad region

Alaska Peninsula

Yukon basin

7,425

Map compilation.

2,200

Mineral statistics

Administration of Alaska branch, including clerical salaries and miscellaneous office expenses 
In addition to the amounts stated a grant of $\$ 75,000$ was made by the Department of the Navy, of which $\$ 55,700$ was expended in 1923 for a survey of a part of Naval Petroleum Reserve No. 4 . The balance, $\$ 19,300$, and an additional grant of $\$ 75,000$ from the Navy were allotted to the continuation of this work. A grant of $\$ 6,000$ from the appropriation for the classification of public lands was devoted to the survey of petroleum lands in Alaska.

Progress of surveys in Alaska, 1898-1923

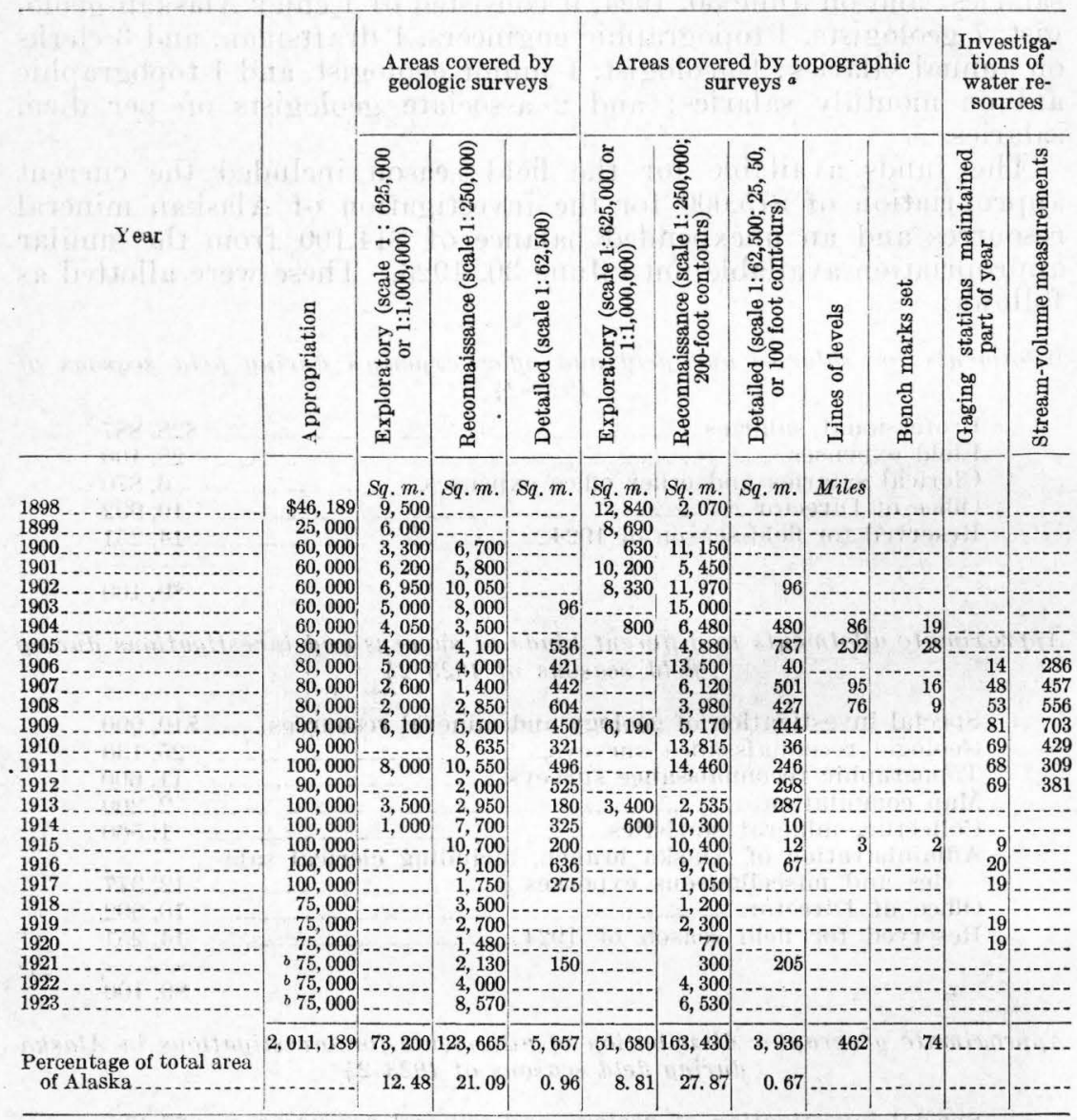

a The Coast and Geodetic Survey, International Boundary Commission, and General Land Office have also made topographic surveys in Alasks. The areas covered by these surveys are, of course, not included in these totals.

$b$ In 1921-1923 additional funds were available; see above.

\section{WORK OF THE YEAR}

Under the appropriation of $\$ 75,000$ and the grant of $\$ 6,000$ for the classification of petroleum lands, 7 field parties were dispatched to Alaska in 1923. These parties included 7 geologists, 2 topographic engineers, and 11 auxiliaries. Five of these were engaged in purely geologic work and 2 in combined geologic and topographic 
work. Naval Petroleum Reserve No. 4 was surveyed in 1923 by three parties, which were engaged in both classes of work and which included three geologists, three topographic engineers, and 17 auxiliaries. In January, 1924, a large expedition led by Philip S. Smith went to northern Alaska to continue the survey of the petroleum reserve. This expedition reached the head of the Colville in March and was in Arctic Alaska at the end of the fiscal year.

Alfred H. Brooks, chief Alaskan geologist, as official delegate to the Pan-Pacific Science Congress, made a journey to Australia within the fiscal year, returning October 10, 1923. While in the office Mr. Brooks gave about 40 per cent of his time to scientific investigations and the preparation of reports and the remainder to administrative work. Stephen R. Capps gave about 40 per cent of his office time to administrative duties as acting chief Alaskan geologist, and R. H. Sargent gave about the same percentage to the supervision of topographic surveys and to the compilation of maps. Miss Lucy M. Graves devoted the larger part of her time to administering the clerical work of the branch and was in charge of the branch during the absence of the chief and the senior Alaskan geologists. Miss Erma C. Nichols devoted about two-thirds of her time to the collection and coordination of the mineral statistics of Alaska.

A. F. Buddington continued his investigation of the geology and mineral resources of southeastern Alaska and gave special attention to the Hyder district and the nickel deposits in the Sitka district.

F. H. Moffit continued his study of the copper deposits of Prince William Sound.

S. R. Capps during July continued his study of the metal deposits of the region along the Alaska Railroad.

R. H. Sargent, with Kirtley F. Mather, geologist, carried a reconnaissance survey from Kamishak Bay to Katmai.

R. K. Lynt, with Walter R. Smith, geologist, mapped an area lying between Katmai on the north and Cold Bay on the south.

George C. Martin continued from July 18 to August 28 his study of the stratigraphy of Alaska Peninsula and gave special attention to the Cold Bay petroleum field and the Chignik district. His office work consisted chiefly of the completion of a report on the Mesozoic geology of Alaska.

J. B. Mertie, jr., carried a geologic reconnaissance survey from Beaver, on the Yukon, to the Chandalar placer district. Later he studied the geology along the Yukon between Beaver and the Tanana.

Sidney Paige led an expedition to investigate the oil resources of Naval Petroleum Reserve No. 4. The field work began about July 15 and ended about September 9. The northern party, including Sidney Paige, geologist, and E. C. Guerin, cadastral engineer, worked from Wainwright around Point Barrow to Dease Inlet and thence up Meade River about 80 miles. The northeastern party, James Gilluly, geologist, and J. E. Whitaker, topographic assistant, went overland from Peard Bay down to Inaru River and explored Topagarok River for 40 miles. The southern party, W. T. Foran, geologist, and Gerald FitzGerald, junior topographer, landed near Cape Beaufort and surveyed the shore line north to Icy Cape. It mapped Kukpowruk River inland for 35 miles, Kokolik River for 25 miles, and Utukok River for 40 miles and explored the lower part of Wainwright Inlet. The Paige expedition mapped in all 2,150 square miles, but the exploration has thrown much light on the topography and geology of 10,000 square miles in northern Alaska.

C. Arthur Hollick completed his studies of the Alaska Tertiary flora and will soon submit his report.

James McCormick was employed in the Alaskan branch for a part of the year in revising the "Geographic dictionary of Alaska" (Bulletin 299).

The publications of the year consisted of a report on the progress of investigations in Alaska in 1921 (Bulletin 739), a bulletin on the Ruby-Kuskokwim region (Bulletin 754), and three chapters of the report on the progress of investigations in Alaska in 1922 (Bulletins 755-A to 755-C). Brief notices of these publications appear elsewhere in this report.

$11580-24-4$ 


\section{TOPOGRAPHIC BRANCH}

\section{ORGANIZATION}

The organization of the topographic branch during the year was as follows:

Chief topographic engineer, C. H. Birdseye.

Atlantic division, topographic engineer in charge, Frank Sutton. ${ }^{1}$

Central division, topographic engineer in charge, W. H. Herron.

Rocky Mountain division, topographic engineer in charge, Glenn S. Smith. (In the absence of Mr. Birdseye Mr. Smith acted as chief topographic engineer.)

Pacific division, topographic engineer in charge, T. G. Gerdine.

Computing section, topographic engineer in charge, E. M. Douglas.

Section of inspection and editing, topographic engineer in charge, W. M. Beaman.

Section of cartography, draftsman in charge, A. F. Hassan.

Map information office, topographic engineer in charge, J. H. Wheat.

Section of relief maps, geographer in charge, J. H. Renshawe.

Section of photographic mapping, topographic engineer in charge, T. P. Pendleton.

\section{PERSONNEL}

The technical force was increased by the appointment of 3 junior topographers, 10 topographic aids, and 5 draftsmen and the reinstatement or transfer of 5 topographic engineers, 2 assistant topographic engineers, 1 junior topographer, and 1 assistant map printer. The force was reduced by 11 resignations and 3 transfers. With these changes the corps now includes 1 chief topographic engineer, 4 topographic engineers in charge of divisions, 4 geographers, 77 topographic engineers, 2 topographers, 41 assistant topographic engineers, 30 junior topographers, 10 topographic aids, 1 map editor, 2 map revisers, 1 assistant map printer, and 16 draftsmen, a total of 189. During the year 8 topographic engineers, 6 assistant topographic engineers, and 8 junior topographers were on furlough. In addition, 37 technical field assistants were employed during the whole or a part of the year. The clerical force comprises 15 clerks of various grades, one of whom is a temporary employee, and one messenger.

\section{PUBLICATIONS}

The published work of the topographic branch for the fiscal year consisted of 68 new standard topographic maps, 17 river plans and profiles, 2 revised State maps, advance photolithographic prints of 106 new topographic maps now in process of engraving, and 34 photolithographs of new topographic maps for which publication has not yet been otherwise provided. Additional publications were a shaded relief map of Kentucky and shaded relief editions of 5 Pennsylvania and 2 West Virginia standard topographic maps. One State map (completely revised) is in press.

Bulletin 709, giving the results of triangulation and primary traverse in the United States for 1916-1918, in one volume, and Bulletin 689 , descriptive of the boundaries, areas, geographic centers, and altitudes of the United States and of the several States, were published during the year.

$1 \mathrm{Mr}$. Sutton was on annual and sick leave and on leave without pay, owing to illness, from January 1 to June 30 . 


\section{APPIOPRIATIONS}

The Federal appropriations for topographic surveys for the fiscal year 1924 were as follows:

$\begin{array}{lr}\text { Topographic surveys } & \$ 500,000.00 \\ \text { Salaries, scientific assistants } & 9,200.00 \\ \text { Special funds for military mapping (contributed by } & \\ \text { War Department) } & \\ & \\ \text { COOPERATION } & 545,248.41 \\ \end{array}$

COOPERATION

Cooperation has been maintained in 19 States and 1 Territory, which contributed the following amounts:

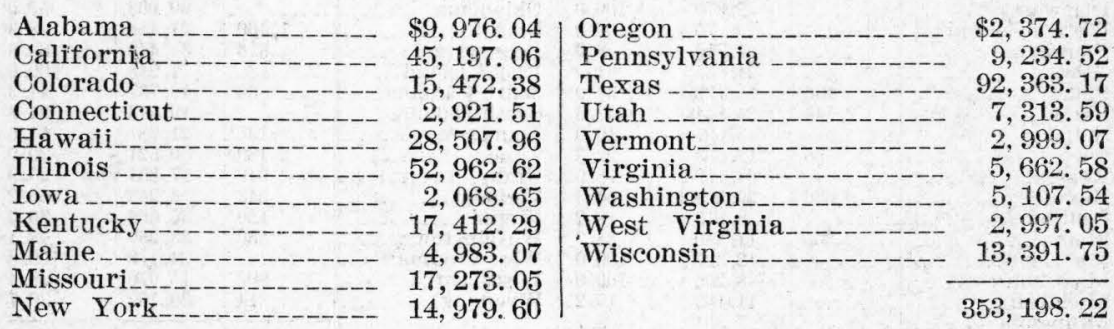

In addition, base-map work was done and paid for by other Federal organizations as follows: For the National Park Service, $\$ 1,021.06$; for the Coal Commission, $\$ 980.65$; for the General Land Office, $\$ 428.99$; for the Federal Board for Vocational Education, $\$ 96.62$. The total amount received from these sources was $\$ 2,527.32$.

The total amount expended from all sources for the work of the topographic branch was $\$ 900,973.95$.

\section{SUMMARY OF RESULTS}

The condition of topographic surveys to June 30, 1924, distinguished as to scale and date, is shown on Plate I.

As shown in the following table, the new area mapped was 16,021 square miles, making the total area surveyed to date in the continental United States, exclusive of Alaska, 1,248,062 square miles, or 41.2 per cent of the entire country. In addition, 644 square miles of resurvey was completed, making the total area of surveys during the year 16,665 square miles. River surveys amounting to 818 linear miles were also made.

In connection with these surveys, 7,781 linear miles of primary levels were run, making 304,975 miles of primary and precise levels run since the authorization of this work by Congress in 1896 . In the course of this work 2,059 permanent bench marks were established.

Triangulation stations to the number of 177 were occupied, and 122 were permanently marked.

Primary traverse lines aggregating 5,832 miles were run, in connection with which 1,450 permanent marks were set.

In addition, 696 square miles of topographic mapping was completed in Hawaii and 228 miles of primary levels were run and 90 bench marks established there. 
Present condition of topographic surveys of the United States and new area surveyed July 1, 1923, to June 30, 1924

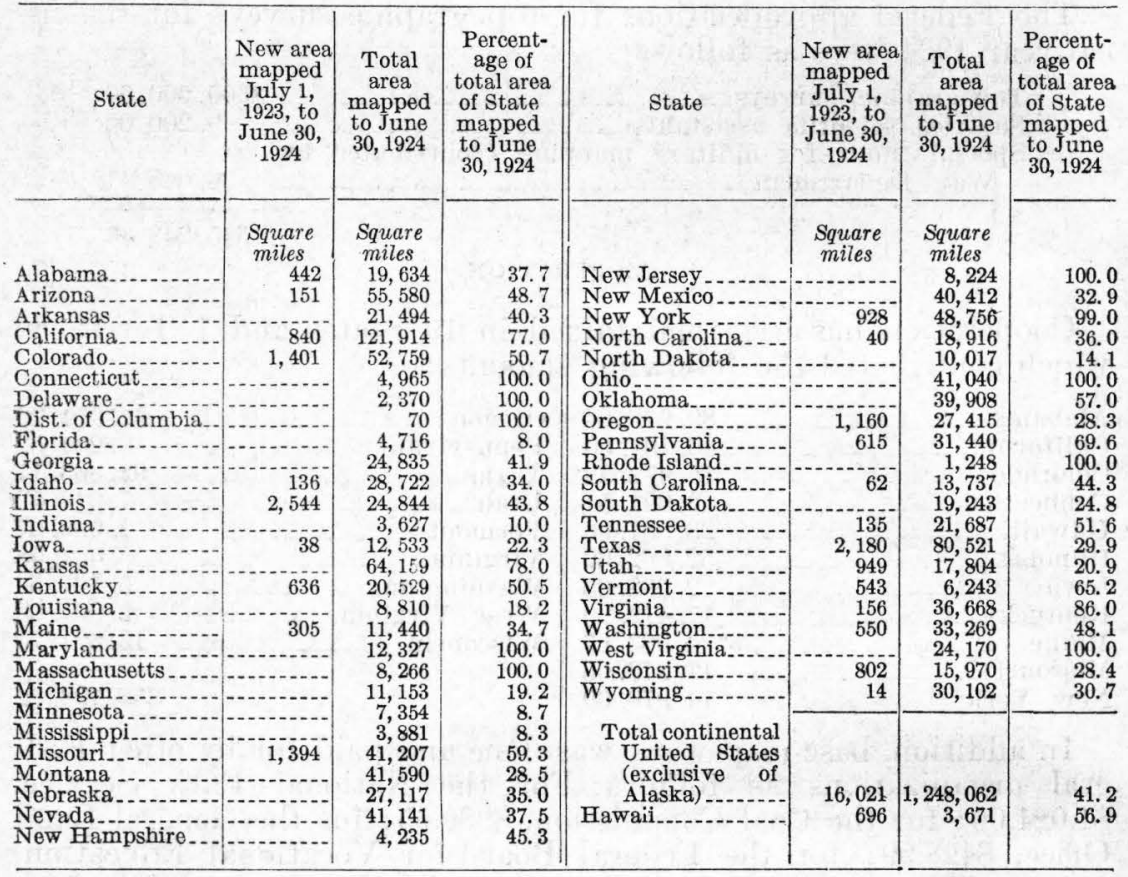

Topographic surveys from July 1, 1923, to June 30, 1924

\begin{tabular}{|c|c|c|c|c|c|c|c|c|c|c|}
\hline \multirow{2}{*}{ State } & \multirow{2}{*}{$\begin{array}{l}\text { Contour } \\
\text { interval }\end{array}$} & \multicolumn{6}{|c|}{ For publication on scale of - } & \multicolumn{3}{|c|}{ Total area surveyed } \\
\hline & & $1: 12,000$ & $1: 20,000$ & $1: 24,000$ & $1: 31,680$ & $1: 62,500$ & $1: 125,000$ & New & $\begin{array}{c}\text { Resur- } \\
\text { vey }\end{array}$ & Total \\
\hline Alabama & Feet & mi. & Sq. mi. & Sq. mi. & Sq. mi. & Sq. mi. & Sq. $m i$. & $S q \cdot m i$. & Sq. mi. & Sq. mi. \\
\hline Arizona- & 50 & & & & & 151 & & 151 & & 151 \\
\hline California & 5,20 & 14 & & 325 & 501 & & & 840 & & 840 \\
\hline Colorado_ & 50,100 & & & & & 781 & 620 & 1,401 & & 1,401 \\
\hline Idaho & 50,100 & & & & & 86 & 50 & 136 & & 136 \\
\hline Illinois.............. & 10,20 & & & & & 2,544 & -.. & 2,544 & & 2,544 \\
\hline $\begin{array}{l}\text { Iowa } \\
\text { Kentucky }\end{array}$ & 20 & & & -7 & & $\begin{array}{r}38 \\
634\end{array}$ & & $\begin{array}{r}38 \\
636\end{array}$ & & 38 \\
\hline $\begin{array}{l}\text { Kentucky } \\
\text { Maine.... }\end{array}$ & $\begin{array}{l}20 \\
20\end{array}$ & & & & & $\begin{array}{l}634 \\
305\end{array}$ & $\cdots$ & $\begin{array}{l}636 \\
305\end{array}$ & & $\begin{array}{l}636 \\
305\end{array}$ \\
\hline Massachusetts & 10 & & 52 & & & & & & 52 & 52 \\
\hline Missouri. & 20 & & & & & 1,394 & & 1,394 & & 1,394 \\
\hline Montana & 10 & & ... & ... & .. & 10 & & & 10 & 10 \\
\hline New York & 20 & & {$\left[\begin{array}{lll}-1 & 0 & 0\end{array}\right.$} & & & 928 & & 928 & & 928 \\
\hline $\begin{array}{l}\text { North Carolina.... } \\
\text { Ohio }\end{array}$ & $\begin{array}{l}20 \\
10\end{array}$ & & & & & $\begin{array}{r}40 \\
532\end{array}$ & & & 532 & $\begin{array}{r}40 \\
532\end{array}$ \\
\hline Oregon. & $\left\{\begin{array}{l}5,10,20 \\
25,100\end{array}\right.$ & \} & & & 40 & 152 & 968 & 1,160 & & 1,160 \\
\hline Pennsylv & & & & & & 615 & & 615 & & 615 \\
\hline Rhode Isla & 5,10 & & 11 & & & & & & 11 & \\
\hline South Carolina & 10,20 & & $\ldots$ & $\cdots$ & - & 62 & & 62 & & 62 \\
\hline $\begin{array}{l}\text { Tennessee_..... } \\
\text { Texas......... }\end{array}$ & 20 & & & & & 135 & & 135 & & 135 \\
\hline Texas..... & $5,10,20$ & & & 373 & & 1,807 & .... & 2,180 & & \\
\hline Utah...... & $\left\{\begin{array}{l}1,5,20 \\
50,100\end{array}\right.$ & \}- & & 280 & 530 & 27 & 112 & 949 & & 949 \\
\hline Vermont.- & 20 & & & & & 543 & & 543 & & 543 \\
\hline Vir & & & & & & 195 & & 156 & 39 & 195 \\
\hline Washingto & 25,100 & & & & & 495 & & 550 & & 550 \\
\hline Wisconsin & 20 & & & & & 802 & & 802 & & 802 \\
\hline Wyoming.- & 10 & & - & 14 & $\ldots+\ldots$ & ..... & -..non & 14 & & 14 \\
\hline Hawaii. & 10.50 & 14 & 63 & 1,032 & 1,071 & 12,680 & 1,805 & 16,021 & 644 & 16,665 \\
\hline & & & & & & & & & & \\
\hline
\end{tabular}




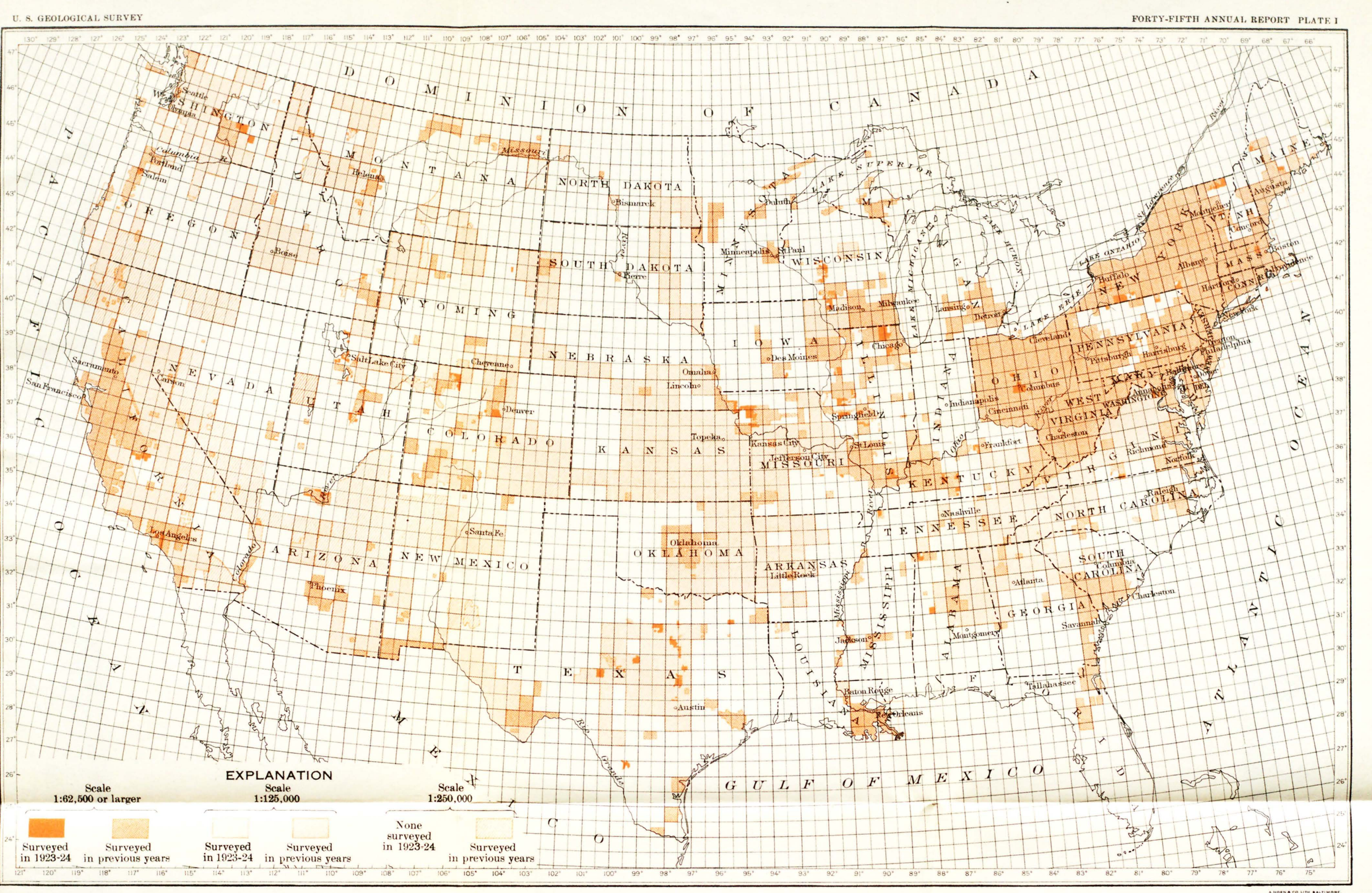

AREAS COVERED BY TOPOGRAPHIC SURVEYS MADE BY UNITED STATES GEOLOGICAL SURVEY PRIOR TO JULY 1 , 1924 AND THE SCALE EMPLOYED FOR EACH AREA

$100 \quad 100^{20} \quad 200 \quad 300 \quad 400 \quad 300$ Miles 
Topographic surveys from July 1, 192s, to June 30, 1924-Continued

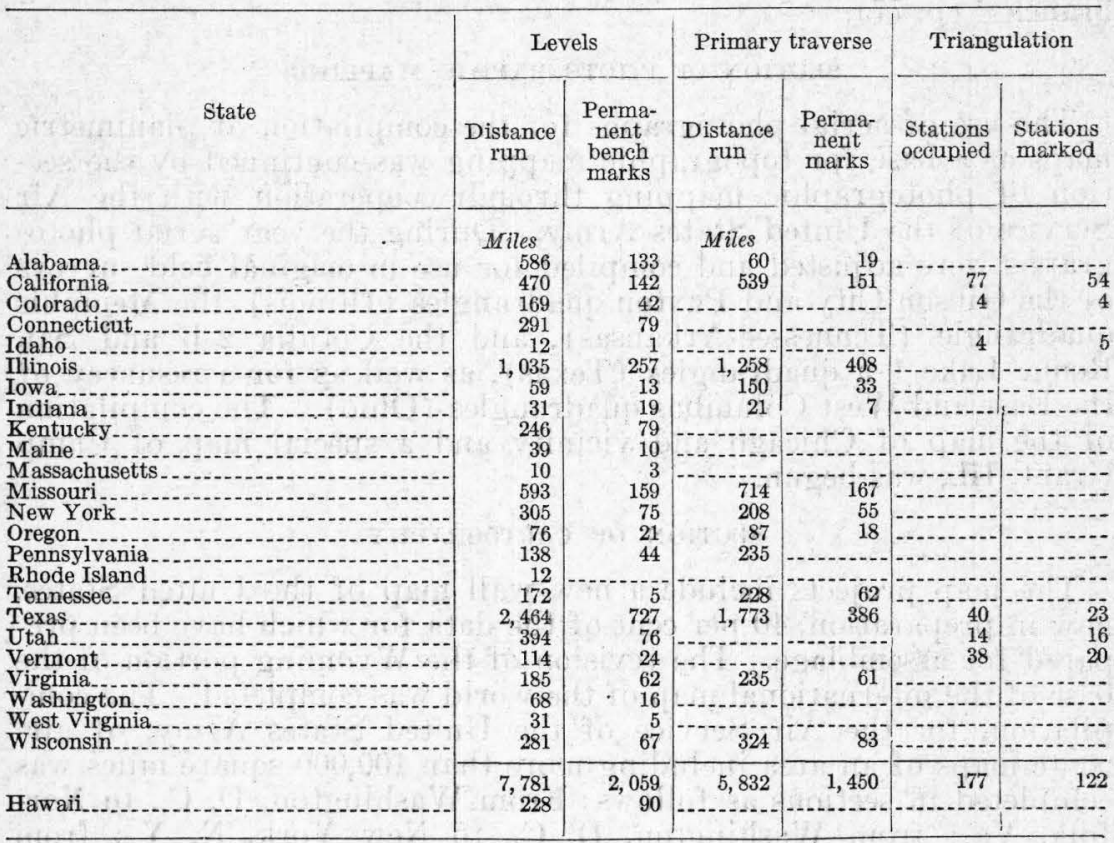

GENERAL OFFICE WORK

Computations for vertical and horizontal control were made, and the results were copied and cataloged by the computing section. The section of relief maps prepared shaded relief maps of Arizona, northern New Jersey, and parts of Pennsylvania and New York, as well as a special map of parts of Arizona, California, Nevada, and Mexico and maps of the Howard, Lock Haven, and Williamsport quadrangles in Pennsylvania. The map information office was engaged in indexing and cataloging the map data available in the several Federal departments and a number of non-Federal organizations and in furnishing miscellaneous map information to the public.

\section{SECTION OF INSPECTION AND EDITING OF TOPOGRAPHIC MAPS}

The section of inspection and editing of topographic maps continued to supervise the office preparation of all topographic maps and to inspect and edit them before reproduction. It also edited a number of maps submitted by other Survey branches and Government bureaus.

The number of topographic maps in progress in the topographic branch (exclusive of those being engraved and printed) ranged from 163 in August to 278 in March; the monthly average was 232. An average of 16 employees were engaged in this section for the year.

James McCormick spent three-quarters of the year in work for the United States Geographic Board and in other special investigations and one-quarter of the year in revising the "Geographic dictionary of Alaska." 
The work of this section is described further under "Publication branch" (p. 77).

\section{SECTION OF PHOTOGRAPHIC MAPPING}

The use of aerial photographs for the compilation of planimetric maps as a base for topographic mapping was continued by the section of photographic mapping through cooperation with the Air Service of the United States Army. During the year aerial photographs were adjusted and compiled for use in original field surveys of the Gibson City and Paxton quadrangles (Illinois), the Memphis quadrangle (Tennessee-Arkansas), and the Cotulla $2-b$ and San Roque Lake 1-a quadrangles (Texas), as well as for a resurvey of the East and West Columbus quadrangles (Ohio). The compilation of the map of Chicago and vicinity and a special map of Camp Grant, Ill., was begun.

\section{SECTION OF CARTOGRAPHY}

The map projects include a new wall map of the United States, now in preparation, 40 per cent of the data for which have been prepared for assemblage. The revision of the Wyoming portion of the base of the international map of the world was completed. The compilation, for the Air Service of the United States Army, of airroute maps of an area including more than 100,000 square miles was completed in sections as follows: From Washington, D. C., to Norfolk, Va.; from Washington, D. C., to New York, N. Y.; from New York, N. Y., to Boston, Mass.; from Dayton, Ohio, to Rantoul, Ill.; from Montgomery, Ala., to New Orleans, La.; and from Chicago, Ill., to Iowa City, Iowa. Other air-route maps are in preparation. Maps of proposed dam sites on Colorado River and a map of Arizona showing their locations were drafted. The results of reconnaissance surveys of streams in Colorado and Wyoming were assembled and redrafted, and a series of maps of Missouri River were prepared. Numerous diagrams and graphs were prepared for the Federal Board for Vocational Education and the Bureau of Education. Projections were constructed for field and office use, the road map of Illinois was further revised for the State, and maps of the Texas-Oklahoma boundary line were prepared for printing.

\section{ATLANTIC DIVISION}

\section{FIELD WORK}

Alabama.-In cooperation with the State geologist of Alabama the survey of the Tuscaloosa quadrangle was completed and that of the Gravelly Springs quadrangle was begun. At the request of the Engineer Corps of the Army the survey of 38 square miles along Tennessee River was completed for a map on the scale of $1: 24,000$ having a contour interval of 5 feet. For the control of this area 17 miles of primary levels were run and 3 permanent bench marks were established.

Alabama-Tennessee.-At the request of the Engineer Corps of the Army 362 miles of primary levels were run along Tennessee River and 27 permanent bench marks were set, to be used by the Corps in the investigation of the Tennessee River basin.

Connecticut.-In cooperation with the Connecticut State Highway Commission for control of new work 291 miles of primary levels were run and 79 permanent marks were established.

Maine.-In cooperation with the Maine State Water Power Commission the survey of the Attean Pond and Burnham quadrangles was completed and that of the Pierce Pond quadrangle was begun. 
Massachusetts. - The resurvey of Camp Devens, Mass., and vicinity was completed, the total area mapped being 52 square miles, for publication on the scale of $1: 20,000$, with a contour interval of 10 feet. For the control of this area 10 miles of primary levels were run and 3 permanent bench marks established. This work was done for the War Department.

New York.-In cooperation with the New York State engineer the survey of the Arcade, Belmont, Franklinville, and Springville quadrangles was completed and that of the Deposit, Rathbone, Rexville, and Wellsville quadrangles was begun.

Pennsylvania.-In cooperation with the Pennsylvania Department of Forests and Waters, Topographic and Geologic Survey, the survey of the Berlin, Cambridge Springs, Meadville, and Towanda quadrangles was completed and that of the Bradford, Lewistown, and Menno quadrangles was begun.

Pennsylvania-New Jersey.-In cooperation with the Pennsylvania Department of Forests and Waters, Topographic and Geologic Survey, the survey of the Bushkill quadrangle was continued. The area mapped was all in Pennsylvania.

Rhode Island.-The resurvey of Block Island, R. I., an area of 11 square miles, was completed, for publication on the scale of $1: 20,000$, with contour intervals of 5 and 10 feet. For the control of this area 12 miles of primary levels were run. This work was done for the War Department.

South Carolina.-The survey of the Williston quadrangle, S. C., was completed.

South Carolina-Georgia.-The survey of the Warrenville quadrangle, S. C.Ga., was completed. The area mapped was all in South Carolina.

T'ennessee.-In preparation for the revision of the maps of the Donelson and Nashville Special quadrangles, Tenn., 228 miles of primary traverse were run and 62 permanent marks set.

Tennessee-Missouri-Kentucky.-The survey of the Reelfoot Lake quadrangle, Tenn.-Mo.-Ky., was completed.

Vermont.-In cooperation with the State geologist of Vermont the survey of the Royalton quadrangle was begun. In addition, the survey of the Irasburg, Jay Peak, and Lake Memphremagog quadrangles was completed for the War Department.

Virginia-Maryland.-The resurvey of the Virginia portion of the Indian Head quadrangle was completed, the total area mapped being 21 square miles, for publication on the scale of $1: 62,500$, with a contour interval of 20 feet.

Virginia-North Carolina.-In cooperation with the State geologist of Virginia the survey of the Danville quadrangle was completed and that of the Axton and Martinsville quadrangles was begun.

West Virginia.-In cooperation with the State geologist of West Virginia the revision of 16 quadrangles was completed and that of 3 quadrangles was begun.

West Virginia-Virginia.-In cooperation with the State geologist of West Virginia the resurvey of the Peterstown quadrangle was begun.

\section{OFFICE WORK}

The drafting of 23 sheets was completed and that of 4 sheets begun. Primary-level circuits were adjusted for 71 quadrangles. Geographic positions were computed for 32 quadrangles.

\section{CENTRAL DIVISION}

\section{FIELD WORK}

Illinois.-In cooperation with the Department of Registration and Education of Illinois the survey of the Alexis, Carlinville, Elgin, Genoa, Harrisburg, Harvard, Havana, Marion, Raymond, Rushville, and Yorkville quadrangles was completed and that of the Beardstown, Griggsville, McHenry, Waverly, and Winchester quadrangles was begun. Additional primary-traverse control has been extended over the Calumet, Chicago, Des Plaines, Evanston, Highwood, and Riverside quadrangles in preparation for the resurvey of this area; 477 miles were run and 218 permanent marks set.

Indiana.-In cooperation with the Culver Military Academy 31 miles of primary levels were run, 19 permanent bench marks established, 21 miles of primary traverse run, and 7 permanent marks set, in connection with the survey of Culver, Ind., and vicinity. 
Iowa - In cooperation with the Iowa State Geological Survey the survey of the Albia quadrangle was begun.

Kentucky.- In cooperation with the State Geological Survey of Kentucky the survey of the Spring Lick quadrangle was completed, that of the Cub Run and Waddy quadrangles was continued, and that of the Scottsville quadrangle was begun. A survey was made of the Burnside area, the total area mapped being 2 square miles, for publication on the scale of $1: 24,000$, with a contour interval of 20 feet. This work was done in such a manner as to be available for future incorporation into the regular map of the quadrangle of which the area surveyed is a part.

Missouri.-In cooperation with the State geologist of Missouri the survey of the Clarksdale, Gower, Maysville, and Plattsburg quadrangles was completed, that of the Darlington and Meramec Springs quadrangles was continued, and that of the Bolckow, Edge Hill, Kearney, Maitland, Stanberry, and Tarkio quadrangles was begun.

Missouri-Kansas.-In cooperation with the State geologist of Missouri the survey of the Atchison No. 2 quadrangle was completed and that of the Atchison No. 1 quadrangle was begun. The area mapped was all in Missouri.

Ohio.-The resurvey of the East and West Columbus quadrangles, Ohio, was completed and that of the Delaware quadrangle was begun.

Wisconsin.-In cooperation with the State geologist of Wisconsin the survey of the La Farge and Viroqua quadrangles was completed, that of the Black River Falls, North Bend, and Pigeon Falls quadrangles was continued, and that of the Bell Center, Fairchild, Osseo, Shamrock, Stoddard, Strum, and Wauzeka quadrangles was begun.

\section{OFFICE WORK}

The drafting of 28 sheets was completed and that of 15 sheets was begun. Primary-level circuits were adjusted for 62 quadrangles. Geographic positions were computed for 87 quadrangles.

\section{ROCKY MOUNTAIN DIVISION}

\section{FIELD WORK}

Arizona.-In cooperation with the National Park Service the survey of the Supai quadrangle and of the parts of the Grand Canyon No. 1, Grand Canyon No. 2, and Shinumo Altar No. 2 that lie within the Grand Canyon National Park was completed. Special plan and profile surveys of Colorado River from Lees Ferry, Ariz., to Black Canyon, Ariz.-Nev., through Marble and Grand canyons, were made for publication on the scale of $1: 31,680$, with a contour interval oi 50 feet, 253 miles of Colorado River being traversed and mapped and 75 miles of surveys carried up side canyons to appropriate controlling elevations. In connection with this work 22 dam sites were surveyed on the scale of 400 feet to 1 inch, with a contour interval of 10 feet.

Colorado.-In cooperation with the State engineer of Colorado the survey of the Evergreen quadrangle was completed and that of the Pagosa Springs and James Peak No. 3 quadrangles was begun. In addition, the survey of the Elk Head Creek and Pilot Knob quadrangles was completed and that of the Pagoda No. 1 quadrangle was begun:

Idaho.-At the request of the Forest Service the survey of the Casto quadrangle, Idaho, was begun. The survey of the Ozone quadrangle was begun for the geologic branch, and a plan and profile survey of Clearwater River and its tributaries was begun for the land-classification branch, 95 linear miles of river being traversed.

Montana.- In cooperation with the National Park Service the resurvey of the St. Mary Lake area, in Montana, covering 10 square miles, was completed.

Fexas.-In cooperation with the Texas State Board of Water Engineers the survey of twenty-six $7 \frac{1}{2}$-minute quadrangles, falling in the following 30 minute quadrangles, was completed: Cleburne, Coleman, Farmersville, Gatesville, Granbury, McKinney, Palo Pinto, San Angelo, Sherwood, Temple, Waco, and Weatherford. The survey of thirty-five $7 \frac{1}{2}$-minute quadrangles, falling in the following 30-minute quadrangles, was begun: Ballinger, Breckenridge, Coleman, Cotulla, Eden, Fort Worth, Gatesville, Georgetown, Granbury, Loma Vista, Palo Pinto, Pearsall, San Roque Lake, Sunset, Taylor, Temple, Waco, and Weatherford. In connection with this work the survey of 10 reservoir sites was completed and that of one was begun, the total area mapped being 372 souare miles, for publication on the scale of $1: 24,000$, with contour inter- 
vals of 5 and 10 feet. This work was so performed that its results may be incorporated into the regular maps of the quadrangles of which the areas surveyed form parts.

Utah.-In cooperation with Box Elder, Salt Lake, Tooele, Utah, and Weber counties, Utah, and the United States Bureau of Reclamation the survey of these counties was continued, the total area mapped being 306 square miles. For the control of these projects 149 miles of primary levels were run, 67 permanent bench marks established, 14 triangulation stations occupied, and 16 triangulation stations permanently marked. This work was done to aid in planning irrigation and drainage systems, and the results will be incorporated in regular topographic maps. In addition, the survey of the Accord Lakes, Ferron, and Monument Peak quadrangles was completed and that of the Kyune, Poison Spring, and Soldier Summit quadrangles was begun, the total area mapped being 480 square miles, for publication on the scale of $1: 31,680$, with a contour interval of 50 feet. A survey of streams in the Uinta Basin, covering 156 linear miles, was made, the total area mapped being 50 square miles, for publication on the scale of $1: 31,680$, with a contour interval of 20 feet. This work was done for land classitication. At the request of the Forest Service the survey of the Fort Douglas quadrangle was begun, the total area mapped being 112 square miles, for publication on the scale of $1: 125,000$, with a contour interval of 100 feet.

Wyoming.-At the request of the Bureau of Mines the survey of a special area in the vicinity of Gillette, Wyo., was completed, the total area mapped being 14 square miles, for publication on the scale of $1: 24,000$, with a contour interval of 10 feet.

\section{OFFICE WORK}

The drafting of 18 sheets was completed and that of 16 sheets was begun. Primary-level circuits were adjusted for 51 quadrangles. Geographic positions were computed for 39 quadrangles.

\section{PACIFIC DIVISION}

\section{FIELD WORK}

California.-In cooperation with the California Department of Public Works the survey of the Burrel, Goshen, Hanford, Laton, Lemoore, Monson, No. 30, Riverdale, and Traver quadrangles was completed and that of quadrangle No. 34 was begun. A part of the Raisin quadrangle was revised. In cooperation with Los Angeles County the survey of the Alhambra, Artesia, Bell, Clearwater, El Monte, Hollywood, Long Beach, Van Nuys, Whittier, and Wilmington quadrangles was completed, the total area mapped being 326 square miles, for publication on the scale of $1: 24,000$, with a contour interval of 5 feet, Airplane photographs were taken by the Army Air Service, which aided in the progress of the mapping. For the control of this work 138 miles of primary levels were run, 38 permanent bench marks established, and 77 triangulation stations occupied, 54 of which were permanently marked. Practically all the expense of this work was paid by Los Angeles County. In cooperation with the East Bay Municipal Utility District 58 miles of primary levels were run and 26 permanent bench marks established for the control of the Laytonville quadrangle. The survey of the Alleghany mining district was completed, the total area mapped being 14 square miles, for publication on the scale of $1: 12,000$, with a contour interval of 20 feet. For the control of this area 41 miles of primary levels were run and 14 permanent bench marks established. This work was done for the geologic branch.

California-Oregon.-A plan and profile survey was made of Klamath River from Keno, Oreg., to the mouth of Scott River, Calif,, a distance of 104 miles. This work was done for the land-classification branch and in cooperation with the California-Oregon Power Co.

Hawaii.-In cooperation with the Territory of Hawaii the survey of the following quadrangles was completed: Honakahau SE. 1/4, Honakahau SW. 1/4, Keahole NE. $1 / 4$, Koolau NW. 1/4, Lanai NE. 1/4, Lanai NW. 1/4, Lanai SW. $1 / 4$, Lanai SE. $1 / 4$, Makelawena SE. $1 / 4$, Makena NE. $1 / 4$, Makena NW. $1 / 4$, Makena SW. $1 / 4$, Makena SE. $1 / 4$, Puako NW. $1 / 4$, Puako NW. $1 / 4$, Puako SW. $1 / 4$, and Puako SE. $1 / 4$. The survey of the following quadrangles was begun: Haleakala NW. 1/4, Kailua NE. 1/4, Kailua N. W. 1/4. Kailua SW. 1/4, and Koolau SW. 1/4.

Oregon.-In cooperation with the State engineer of Oregon the survey of the Stayton quadrangle was completed. The survey of the Waldo Lake quadrangle was completed and that of the Mount Hood quadrangle was begun. 
This work was done for the Forest Service. The survey of the Twickenham quadrangle was continued for the geologic branch. A plan and profile survey of Rogue River, covering 113 linear miles of the river, was continued, the total area mapped being 40 square miles, for publication on the scale of $1: 31,680$, with contour intervals of 5 and 10 feet; and a plan and profile survey of Illinois River, covering 66 linear miles of the river, was begun. This work was done for the land-classification branch and in cooperation with the CaliforniaOregon Power Co. In addition, a plan and profile survey of Umpqua River, covering 31 linear miles of river, was begun for the land-classification branch. In connection with these surveys several dam sites were surveyed.

Washington.-In cooperation with the Washington State Department of Conservation and Development the survey of the Washtucna, Wheeler, and Schrag quadrangles was completed and that of the Chewelah quadrangle was begun. In addition the survey of the Mount Rainier quadrangle was begun, the total area mapped being 20 square miles, for publication on the scale of $1: 125,000$, with a contour interval of $\mathbf{1 0 0}$ feet. This work was done for the Forest Service.

\section{OFFICE WORK}

The drafting of 36 sheets was completed and that of 7 sheets was begun. Primary-level circuits were adjusted for 20 quadrangles. Geographic positions were computed for 49 quadrangles.

\section{WATER-RESOURCES BRANCH}

\section{ORGANIZATION}

The work of the water-resources branch was conducted under the supervision of N. C. Grover, chief hydraulic engineer, and is organized in five divisions:

Division of surface water, John C. Hoyt, hydraulic engineer, in charge.

Division of ground water, O. E. Meinzer, geologist, in charge.

Division of quality of water, W. D. Collins, chemist, in charge.

Division of power resources, A. H. Horton, hydraulic engineer, in charge.

Division of land-classification investigations, N. C. Grover, chief hydraulic engineer, in charge.

\section{PERSONNEL}

During the year the technical force was reduced 11 and was increased 29, a net increase of 18 . At the end of the year the force consisted of 1 chief hydraulic engineer, 33 hydraulic engineers, 12 engineers, 25 assistant engineers, 35 junior engineers, 4 geologists, 3 assistant geologists, 1 chemist, 3 associate chemists, and 8 classifiers, a total of 125 . Of this number 4 hydraulic engineers, 2 engineers, 2 assistant engineers, 5 junior engineers, and 1 assistant geologist were employed occasionally. In addition the advisory board of the superpower investigation was dissolved and the appointments of the 13 members who gave occasional service in the study of superpower problems were canceled.

In the clerical force there were 9 separations and 9 accessions, and at the end of the year the force numbered 33. Of this number 6 have been employed only at times. One skilled laborer also was employed occasionally.

\section{ALLOTMENTS}

The appropriation for gaging streams was $\$ 170,000$. In addition $\$ 71,427.16$ of the appropriation for the classification of lands was expended for field work by the water-resources branch. Of the total appropriations 66 per cent was allotted to work in public-land States. The cooperative funds made available by State allotments have been increased in some States and decreased in others, and the changes have necessitated corresponding adjustments of this work. The total 
amount of these funds available for work to be done during the year was $\$ 282,002.47$.

Allotments of funds for gaging streams, 1923-24

Administration, general

Branch administration

Inspection

Computations

$\$ 16,711.52$

$13,000.00$

$40,211.52$

Surface water :

Connecticut

Maine

New Hampshire

Vermont

Massachusetts

New York

New Jersey

Middle Atlantic States_

North Carolina

Tennessee-Kentucky _-

Ohio

Texas

Wisconsin

Minnesota

Iowa

Illinois

Missouri

Kansas

Colorado, Wyoming,

New Mexico
$9,500.00$

1, 000.00

Surface water-Continued.

Montana

North Dakota.

Utah

Nevada

Idaho (Boise)

Idaho (Idaho Falls)

Oregon _...-...-.

Washington

California

Hawaii-

Field____- $\$ 3,500$

Washington_ 1,000

$2,500.00$

5, 500.00

3, 000.00

4, 000.00

4, 000.00

3, 000.00

3, 000,00

5, 000.00

$3,500.00$

300.00

2, 000.00

1, 500.00

4, 000.00

$3,500.00$

7, 000.00
$\$ 5,000.00$ 300.00

$5,000.00$

2, 500.00

3, 900. 00

1, 100.00

$5,000.00$

5, 000.00

$5,500.00$

3, 500.00

4, 500. 00

$97,100.00$

$11,500.00$

$13,500.00$

7, 000,00

500.00

188. 48

$170,000.00$

\section{COOPERATION}

States.- The following amounts were expended by States from cocperative allotments. In addition, several State agencies cooperated by furnishing office quarters and occasional services in field and office.

Alabama

$\$ 60.00$

Arizona :

Stream gaging.

Colorado River

$\$ 11,799.99$

Ground water, San Pedro Valley

7, 000.00

850.00

California :

State________ $22,582.59$

County and city

8, 464.62

Colorado :

State

1, 500.00

Municipal

200. 00

Florida

Hawaii

Idaho:

State Department of Reclamation-

Outside of Snake River basin

Snake River basin

12, 194. 87

$2,175.06$

922.88

Bureau of Mines and Geology

\section{Illinois :}

State

3, 755.38

Municipal

60.00

15, 292. 81

19. 649.99

$31,047.21$

1. 700.00

1. 800.00

18, 439.76

3, 815. 38 
Iowa :

State Highway Commission

$\$ 2,459.04$

State Geological Survey

749. 92

Kansas

Kentucky

Maine

Massachusetts

Minnesota

Missouri

Montana

Nevada

New Hampshire

New Jersey:

Stream gaging.

$9,354.28$

Ground water

$5,084.24$

New York:

State

County and city

$10,492.00$

592.84

North Carolina

North Dakota:

Stream gaging

817. 00

Ground water

800.00

Ohio

Oregon:

State

6, 428. 24

Municipal

1, 750.83

Tennessee

Texas:

State Board of Water Engineers

Municipal

$62,700.00$

292. 41

Utah

Washington:

State

Municipal

$4,157.89$

695. 36

West Virginia :

State

495. 22

Municipal

29. 30

Wisconsin

524.52

$6,252.34$

$6,106.34$

$62,992.41$

$3,102.68$

$4,853.25$

, 208. 96

330. 00

$5,107.11$

$3,059.86$

483. 49

$8,774.51$

$6,442.50$

$1,449.37$

1, 807. 79

$14,438.52$

$11,084.84$

$5,919.67$

$1,617.00$

$24,866.43$

8, 179.07

$4,683.55$

Wyoming

282, 002.47

The work done under cooperative agreements with the States has been restricted to studies of stream flow, except in Arizona, Connecticut, Idaho, New Jersey, and North Dakota, where groundwater investigations also have been made. (See p. 63.)

Bureau of Reclamation.-The measurement of streams that are to furnish water to reclamation projects under construction was continued in cooperation with the United States Bureau of Reclamation. The field work was done by Survey engineers who were employed where the measurements were made, and the cost was met by the Bureau of Reclamation through transfer of funds. Geologic investigations of reservoir sites or ground-water supplies were made for the Bureau of Reclamation in Idaho, New Mexico, Oregon, and Washington. (See pp. 62-64.) 
Office of Indian Affairs.-In accordance with authorization by the Office of Indian Affairs, stream gaging was continued on the Crow, Fort Hall, Yakima, Colville, Klamath, Wind River Diminished, Western Shoshone, Walker River, and Uinta Indian reservations.

National Park Service.-Streams in the Yosemite and Yellowstone national parks were measured during the year at stations maintained in cooperation with the National Park Service.

Forest Service.-A study of stream flow in the Angeles National Forest, in southern California, was continued in cooperation with the Forest Service. Stream gaging in the Arapaho and Uncompahgre national forests was done by the Forest Service, the cost of which was reimbursed by the Geological Survey.

City of San Francisco.- - In connection with the storage of the water of Tuolumne River in Hetch Hetchy Valley as a water supply for the city of San Francisco, measurement of that stream was continued in cooperation with the city government.

Federal Power Commission:-Projects of the Federal Power Commission in Arizona, New Mexico, and Idaho were examined, and the examination of one in Oregon is in progress. The operation of six licensees of the commission in California, four in Oregon, three in Idaho, two in Washington, one in Idaho-Oregon, and one in $\mathrm{Ne}$ vada were supervised by the Geological Survey, as well as the operations of six permittees of the commission in Oregon, three in Arizona, four in Idaho, two in California, one in Utah, one in UtahWyoming, one in New Mexico, and one in Montana. All stream gaging by permittees of the commission is done in cooperation with the Geological Survey. Such cooperative stream gaging is in progress in Alabama, Arizona, Arkansas, California, Colorado, Florida, Idaho, Illinois, Indiana, Kentucky, Louisiana, Michigan, Minnesota, Missouri, Montana, Nevada, New Mexico, North Carolina, Oregon, Pennsylvania, South Carolina, Utah, Virginia, Washington, West Virginia, Wisconsin, and Wyoming.

Office of the Chief of Engineers.-Stream gaging has been done in the basins of Tennessee and Cumberland rivers in cooperation with the office of the Chief of Engineers.

\section{PUBLICATIONS}

The publications of the year prepared by the water-resources branch comprised 17 reports and 2 separate chapters. Titles and brief summaries of these publications are given elsewhere in this report. At the end of the year 27 other reports were in press and 8 manuscripts were awaiting editorial work.

DIVISION OF SURFACE WATER

\section{ORGANIZATION}

The work of the division of surface water consists primarily of the measurement of the flow of rivers, but it includes also special investigations of conditions affecting stream flow and the utilization of 
the streams. In carrying on the work the United States is divided into 23 districts, including Hawaii. The district offices and engineers in charge are as follows:

New England: C. H. Pierce, Customhouse, Boston, Mass.

New York: A. W. Harrington, Journal Building; Albany, N. Y.

New Jersey : O. W. Hartwell, Statehouse, Trenton, N. J.

Middle Atlantic and Ohio River: A. H. Horton, Washington, D. C.

South Atlantic and eastern Gulf: W. E. Hall, 6 Government Street, Asheville, $\mathbf{N}$. C.

Tennessee: W. R. King, Municipal Building, Chattanooga, Tenn.

Ohio: Lasley Lee, Brown Hall, Ohio State University, Columbus, Ohio.

Upper Mississippi River: S. B. Soulé, Capitol Building, Madison, Wis.

Illinois: H. E. Grosbach, Kimball Building, Chicago, Ill.

Iowa : J. B. Spiegel, State Highway Commission Building, Ames, Iowa.

Kansas: H. B. Kinnison, Federal Building, Topeka, Kans.

Missouri : H. C. Beckman, Rolla, Mo.

Upper Missouri River: W, A. Lamb, Montana National Bank Building Helena, Mont.

Rocky Mountain: Robert Follansbee, Post Office Building, Denver, Colo.

Great Basin: A. P. Purton, Federal Building, Salt Lake City, Utah.

Idaho: C. G. Paulsen, Idaho Building, Boise, Idaho.

Snake River Basin: G. C. Baldwin, Federal Building, Idaho Falls, Idaho.

Washington: G. L. Parker, Federal Building, Tacoma, Wash.

Oregon: F. F. Henshaw, Post Office Building, Portland, Oreg.

California: H. D. MeGlashan, Customhouse, San Francisco, Calif.; suboffice, Federal Building, Los Angeles, Calif.

Arizona: W. E. Dickinson, care of University of Arizona, Tueson, Ariz.

Texas: C. E. Ellsworth, Capitol Building, Austin, Tex.

Hawaii : E. D. Burchard, Capitol Building, Honolulu, Hawaii.

\section{CHARACTER AND METHOD OF WORK}

Field investigations necessary to the work are made from the district offices, where the results are examined and corrected, if correction is necessary, to insure their accuracy and completeness. At selected gaging stations the volume of water carried by the streams is measured and records of stage and other data are collected from which the daily flow of the streams is computed. The data thus collected are transmitted from the district offices to Washington, where they are reviewed in the computing section and prepared for publication. By this review the records obtained in different parts of the country are brought to a uniform standard, and standardization is further effected through annual conferences of the engineers.

At the end of the year 1,673 gaging stations were being maintained, including 73 in Hawaii; 317 stations were discontinued, and 399 new stations established during the year. Records for about 162 additional stations were received, ready for publication, from Government bureaus and private persons, and a number of Government and State organizations and individuals cooperated in the maintenance of the regular gaging stations. 
Gaging stations and cooperating parties for the year ended June 30, 1924

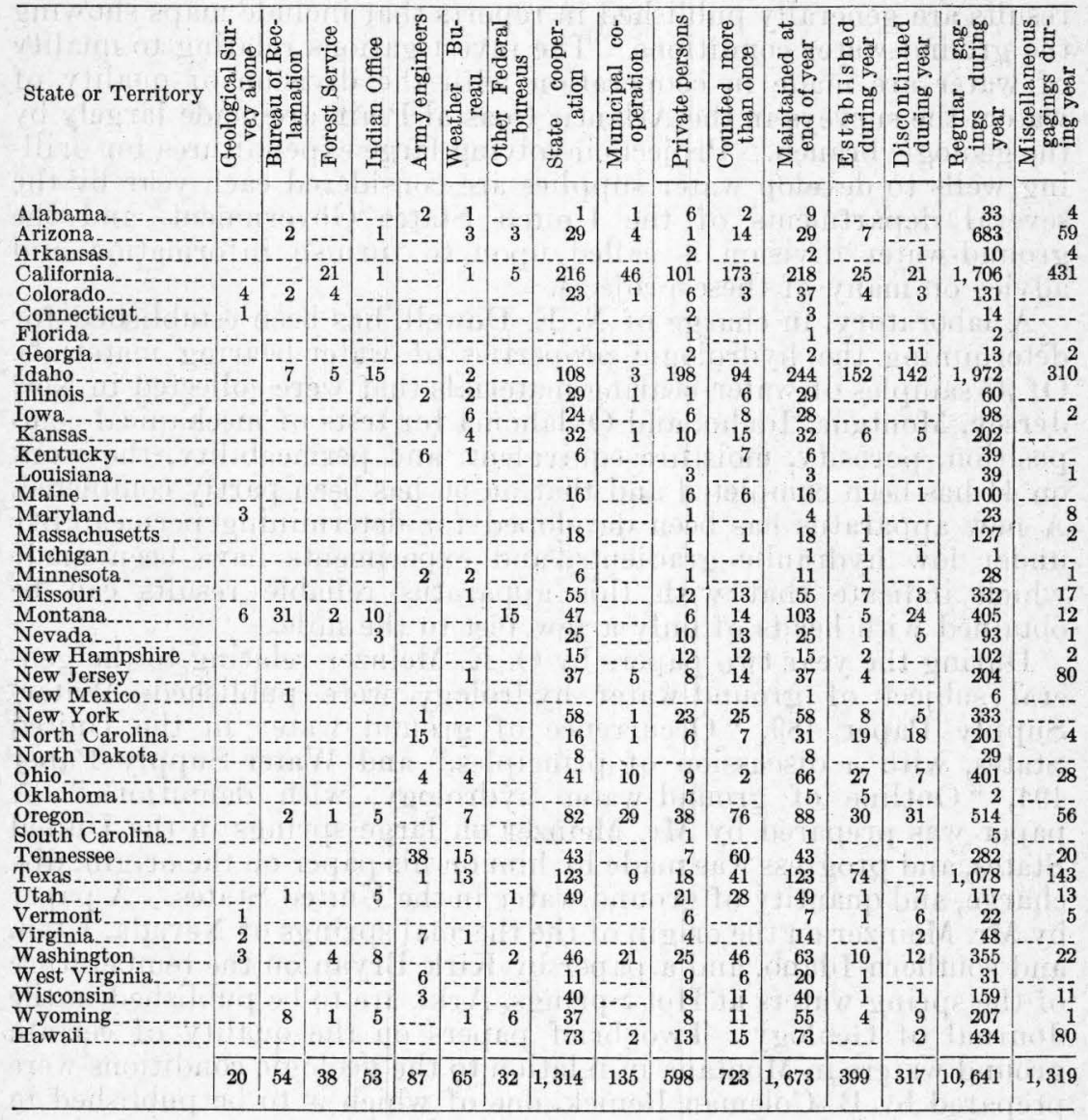

PUBLICATIONS

For convenience and uniformity in publications, the United States has been divided into 12 primary drainage basins, and the results of stream measurements are published annually in a series of progress reports that correspond to these 12 divisions; the records for the twelfth division are published in three papers. In addition to the progress reports, special reports on hydraulic subjects have been com. pleted for publication during the year.

\section{DIVISION OF GROUND WATER}

\section{GENERAL FEATURES}

The division of ground water investigates the waters that lie below the surface - their occurrence, quantity, quality, and head; their recovery through wells and springs; and their utilization for domestic, industrial, irrigation, and public supplies and at watering places for livestock and desert travelers. Each year surveys are made of 
selected areas where problems of water supply are urgent, and the results are generally published in reports that include maps showing the ground-water conditions. The investigations relating to quality of water are made in cooperation with the division of quality of water; the surveys in the Atlantic Coastal Plain are made largely by the geologic branch. Projects involving large expenditures for drilling wells to develop water supplies are considered each year by the several departments of the United States Government, and the ground-water division is called upon to furnish information and advice on many of these projects.

A laboratory, in charge of N. E. Dowell, has been established for determining the hydrologic properties of water-bearing materials. Of 97 samples of water-bearing materials that were collected in New Jersey, Montana, Idaho, and Oklahoma for tests of mechanical composition, porosity, moisture equivalent, and permeability, the work on 41 has been completed and that on 56 has been partly completed. A new apparatus has been developed for determining permeability under low hydraulic gradients, and experiments have been made which indicate that with this apparatus reliable results can be obtained with heads of only a. few feet to the mile.

During the year two papers by O. E. Meinzer relating to the general subject of ground-water hydrology were published-WaterSupply Paper 489, "Occurrence of ground water in the United States, with a discussion of principles," and Water-Supply Paper 494, "Outline of ground-water hydrology, with definitions." \& paper was prepared by Mr. Meinzer on large springs in the United States, and progress was made by him on his paper on the origin, discharge, and quantity of ground water in the United States. A paper by Mr. Meinzer on the origin of the thermal springs of Nevada, Utah, and southern Idaho, and a paper by Kirk Bryan on the temperature of the spring waters at Hot Springs, Ark., are to be published in the Journal of Geology. Two brief papers on the quality of certain ground waters in Montana in relation to the geologic conditions were prepared by B. Coleman Renick, one of which is to be published in the Journal of Geology and the other as a contribution to hydrology.

In February, 1924, Mr. Meinzer delivered a course of lectures on ground water at the annual meeting of the Minnesota Well Drillers Association in St. Paul. These lectures are being published in the Howell Drillers News.

Cooperation with the committee on physiography was continued through Mr. Meinzer, who serves on that committee. Several manuscripts for geologic folios were examined with respect to their treatment of ground water.

\section{WORK BY STATES}

Arizona.-Progress was made on a report on the geology and water resources of San Pedro Valley, Ariz., by Kirk Bryan, of the Geological Survey, and G. E. P. Smith, of the Arizona Agricultural Experiment Station.

Arkansas.- Studies of the temperature and source of the hot-water supply in the Hot Springs National Park, Ark., were continued by Mr. Bryan.

Califormia.-A comprehensive report entitled "The Mohave Desert regiona geographic, geologic, and hydrologic reconnaissance," was completed by D. G. Thompson for publication as a water-supply paper. This paper was made available to the public in manuscript form, copies of it being filed in the Washington and Los Angeles offices of the Geological Survey. Water 
levels were measured in selected wells in southern California, as in previous years, under the direction of F. C. Ebert. At the request of the Director of the Veterans' Bureau an examination was made relating to a water supply for a proposed hospital near Livermore, Calif. Charles H. Lee made this examination.

Connecticut.-A paper on ground water in the Pomperaug drainage basin, Conn., with special reference to intake and discharge, by 0 . E. Meinzer and N. E. Dowell, was completed and is to be published as a water-supply paper. The work was done in cooperation with the State Geological and Natural History Survey.

Hawaii.-Field work was begun by $H$. T. Stearns in the Kau district, Island of Hawaii, to complete an investigation of the geologic and groundwater conditions left unfinished by the resignation of $W$. O. Clark.

Idaho.-Observations were continued in the Mud Lake basin, Idaho, through cooperation with C. G. Paulsen, district engineer of the surface-water division in Idaho. A brief report on the basin, including the records obtained during the first two years of the investigation, was prepared by $H$. $T$. Stearns and L. L. Bryan. Progress was also made on the final report on the Mud Lake basin. A report by A. M. Piper on the Goose Creek basin was published as Bulletin 6 of the Idaho Bureau of Mines and Geology, and a report by 0 . E. Meinzer on the Pahsimeroi Valley was published as Pamphlet 9 of that bureau. During the year $\mathrm{Mr}$. Piper completed his report on the geology and water resources of the Bruneau River basin and began field work on the artesian-water conditions in Camas Prairie. Mr. Stearns examined the region of recent lavas west of Arco and prepared a report for the National Park Service recommending the withdrawal of an area in this region as a national monument. The area has since been established as the Craters of the Moon National Monument. The ground-water work in Idaho is done in cooperation with the State Bureau of Mines and Geology. The work in the Mud Lake basin received financial support from the United States General Land Office and the Idaho Bureau of Reclamation. At the request of the United States Bureau of Reclamation investigations were made by Mr. Stearns of the Island Park reservoir site of the Dubois project and of two reservoir sites of the Empire irrigation district. Reports on both projects were transmitted to the Commissioner of the Bureau of Reclamation.

Montana.-George M. Hall completed his report on Yellowstone and Treasure counties, Mont., and made progress on his report on Big Horn County. He also completed field work in Fergus County. B. Coleman Renick made a ground-water survey of the central and southern parts of Rosebud County and nearly completed a report thereon. An examination of ground-water conditions in the vicinity of Ingomar was made by Mr. Renick, and a manuscript report based on this work was sent to the citizens of Ingomar.

New Jersey.-An investigation of the quantities of ground water available for public and industrial supplies in New Jersey has been in progress during the year in cooperation with the State Department of Conservation and Development. The work has been in charge of D. G. Thompson, who has been assisted at times by F. Clark Rule and H. C. Barksdale. Special attention was given to the water supplies at Atlantic City and Camden, and experiment stations were established at the pumping plants of Atlantic City and Perth Amboy.

New Mexico-At the request of the Bureau of Reclamation a brief field study of the ground-water supplies available for irrigation in Estancia Valley, N. Mex., was made by 0 . E. Meinzer and Charles $H$. Lee, and a report, prepared by Mr. Lee, was transmitted to the Bureau of Reclamation.

North Dakota.- The decline of the artesian water supply in the Edgeley quadrangle, N. Dak., has been under observation for nearly ten years, chiefly by H. A. Hard. In the fall of 1923, through the cooperation of the North Dakota Geological Survey, the quadrangle was covered by C. E. Turnbaugh, an experienced artesian-well driller, who measured the discharge of all the artesian wells. A paper based on records obtained for several years was prepared by O. E. Meinzer and H. A. Hard on the artesian water supplies of the Dakota sandstone in North Dakota, with special reference to the Edgeley quadrangle. It will be published as Water-Supply Paper 520-E. Progress was $11580-24-5$ 
made by Howard E. Simpson, water geologist of the State Geological Survey, on a comprehensive report on the ground-water resources of North Dakota.

Oklahoma.-At the request of the city of Enid, Okla., Mr. Renick made an examination to discover additional ground-water supplies for that city and prepared a report giving the results of his work. This report was transmitted to the mayor of the city and was afterward published by the Survey as Water-Supply Paper 520-B.

Oregon.-At the request of the Bureau of Reclamation Kirk Bryan examined the reservoir site of the Owyhee irrigation project, Oreg., and prepared a report on the subject, which was transmitted to the Commissioner of the Bureau of Reclamation.

South Carolina.-Progress was made on a report on ground water in the Coastal Plain of South Carolina by C. W. Cooke, of the geologic branch.

Texas.-A report on ground water in the Coastal Plain of Texas southwest of Brazos River, by Alexander Deussen, was completed and is to be published as a water-supply paper.

Virginia.-At the request of the city of Purcellville, Va., an examination of the ground-water conditions in that vicinity was made by $\mathrm{Mr}$. Hall, and a report based on this examination was transmitted to the city officials.

Washington.--Kirk Bryan, who in April, 1923, had been assigned as geologist to an investigation of the Columbia Basin project, Wash., by the United States Bureau of Reclamation, completed his field work and prepared a report, which was transmitted to the Commissioner of the Bureau of Reclamation. He also made a preliminary investigation and report on the reservoir site for the Cle Elum project. At the request of the Department of Justice an examination was made by Mr. Bryan as to an additional water supply for the Federal Prison on McNeil Island, and a report thereon was transmitted to the Superintendent of Prisons.

\section{DIVISION OF QUALITY OF WATER}

During the year 819 samples of water were analyzed, and studies were made of several methods of water analysis. Analyses were made for ground-water reports on Rosebud County, Mont. (123 analyses), Fergus County, Mont. (60), Pomperaug Valley, Conn. (11), and Enid, Okla. (5). Analytical work was practically completed for reports on quality of water in Florida (330 analyses) and on Pecos River, Tex. (91) ; work was started on reports on quality water in New Jersey (103) and in Rhode Island (30). Manuscripts of three ground-water reports and proof of two reports were reviewed and checked with reference to statements in regard to quality of water and tabulation of analyses. A brief report on the temperature of waters was practically completed. The text of a report on the production of mineral water in 1922 was prepared for the division of mineral resources, and a paper on the determination of manganese in water was prepared for publication in Industrial and Engineering Chemistry.

\section{DIVISION OF POWER RESOURCES}

The work of the division of power resources during the year comprised the preparation of monthly reports of the production of electricity and consumption of fuel by public-utility power plants, of reports on the stock of coal on hand at such plants at different dates, and of a report on the developed water power of the United States.

The monthly reports are based on reports submitted by publicutility companies. About 4,000 power plants, each having a monthly output of 10,000 kilowatt-hours or more, are requested to submit reports of their production of electricity and consumption of fuel. 
The total capacity of the generators in these plants in January, 1924, was about $17,800,000$ kilowatts. Reports received represent over 95 per cent of the total generating capacity of these plants. Each report is published about 30 days after the end of the last month included in it. The following tables show the power and fuel statistics for the calendar years 1919 to 1923 :

Electricity produced at public-utility power plants in the United States, 1919-1923

\begin{tabular}{|c|c|c|c|c|c|c|c|c|}
\hline \multirow[b]{2}{*}{ Year } & \multicolumn{2}{|l|}{ Total } & \multicolumn{3}{|c|}{ Water power } & \multicolumn{3}{|c|}{ Fuel power } \\
\hline & $\begin{array}{l}\text { Kilowatt- } \\
\text { hours }\end{array}$ & $\begin{array}{c}\text { Change } \\
\text { from } \\
\text { previous } \\
\text { year } \\
\text { (per } \\
\text { cent) }\end{array}$ & $\begin{array}{c}\text { Kilowatt- } \\
\text { hours }\end{array}$ & $\begin{array}{l}\text { Per } \\
\text { cent } \\
\text { of } \\
\text { total }\end{array}$ & $\begin{array}{c}\text { Change } \\
\text { from } \\
\text { rrevious } \\
\text { year } \\
\text { (per } \\
\text { cent) }\end{array}$ & $\begin{array}{c}\text { Kilowatt- } \\
\text { hours }\end{array}$ & $\begin{array}{l}\text { Per } \\
\text { cent } \\
\text { of } \\
\text { total }\end{array}$ & $\begin{array}{l}\text { Change } \\
\text { from } \\
\text { previous } \\
\text { year } \\
\text { (per } \\
\text { cent) }\end{array}$ \\
\hline $\begin{array}{l}1919 \ldots . \ldots \\
1920 \ldots \ldots \\
1921 \ldots \ldots \\
1922 \ldots \ldots \\
1923 \ldots \ldots\end{array}$ & $\begin{array}{l}38,921,000,000 \\
43,555,000,000 \\
40,976,000,000 \\
47,659,000,000 \\
55,674,000,000\end{array}$ & $\begin{array}{r}+11.9 \\
-5.9 \\
+16.3 \\
+16.8\end{array}$ & $\begin{array}{l}14,606,000,000 \\
16,150,000,000 \\
14,971,000,000 \\
17,206,000,000 \\
19,348,000,000\end{array}$ & $\begin{array}{l}37.5 \\
37.1 \\
36.5 \\
36.1 \\
34.8\end{array}$ & $\begin{array}{r}+10.6 \\
-7.3 \\
+14.9 \\
+12.4\end{array}$ & $\begin{array}{l}24,315,000,000 \\
27,405,000,000 \\
26,005,000,000 \\
30,453,000,000 \\
36,327,000,000\end{array}$ & $\begin{array}{l}62.5 \\
62.9 \\
63.5 \\
63.9 \\
65.2\end{array}$ & $\begin{array}{r}+12.7 \\
-5.1 \\
+17.1 \\
+19.3\end{array}$ \\
\hline
\end{tabular}

Fuel consumed in the production of power at public-utility plants in the United States, 1919-1923

\begin{tabular}{|c|c|c|c|c|c|c|}
\hline \multirow[b]{2}{*}{ Year } & \multicolumn{2}{|c|}{ Coal } & \multicolumn{2}{|c|}{ Fuel oil } & \multicolumn{2}{|c|}{ Gas } \\
\hline & Short tons & $\begin{array}{c}\text { Change } \\
\text { from } \\
\text { previous } \\
\text { year (per } \\
\text { cent) }\end{array}$ & Barrels & $\begin{array}{c}\text { Change } \\
\text { from } \\
\text { previous } \\
\text { year (per } \\
\text { cent) }\end{array}$ & M cubic feet & $\begin{array}{l}\text { Change } \\
\text { from } \\
\text { previous } \\
\text { year (per } \\
\text { cent) }\end{array}$ \\
\hline $\begin{array}{l}1919 \\
1920 \\
1921 \\
1922 \\
1923\end{array}$ & $\begin{array}{l}35,100,000 \\
37,124,000 \\
31,585,000 \\
34,179,000 \\
38,954,000\end{array}$ & $\begin{array}{r}+5.8 \\
-14.9 \\
+8.3 \\
+14.0\end{array}$ & $\begin{array}{l}11,050,000 \\
13,123,000 \\
12,045,000 \\
13,197,000 \\
14,679,000\end{array}$ & $\begin{array}{r}+18.8 \\
-8.2 \\
+9.6 \\
+11.2\end{array}$ & $\begin{array}{l}21,406,000 \\
24,702,000 \\
23,722,000 \\
27,172,000 \\
31,433,000\end{array}$ & $\begin{array}{r}+15.4 \\
-4.0 \\
+14.5 \\
+15.7\end{array}$ \\
\hline
\end{tabular}

Reports on the stock of coal held by electric public-utility power plants were made for inclusion in reports on commercial stocks of coal undertaken by the Bureau of the Census, Department of Commerce, and the Geological Survey under authority of the Federal Fuel Distributor. Four of these reports were prepared during the year, giving the stock of coal held on the first day of the months of July, August, and September, 1923, and January, 1924.

\section{DIVISION OF LAND-CLASSIFICATION INVESTIGATIONS}

The division of land-classification investigations performed certain technical work required for the classification of the public lands with respect to their water resources. The work is done mainly by the use of funds allotted by the land-classitication branch and by men from both branches who are sent to the field in summer and spend the winter in the office in preparing reports. The work comprises the examination of public lands for designation under the enlarged 
and stock-raising homestead laws and the examination of streams and neighboring lands for the classification of public lands with respect to their value for water power or irrigation.

\section{ENLARGED AND STOCK-RAISING HOMESTEADS}

The work of examining lands for classification under the enlarged and stockraising homestead laws was continued during the year, but more time was given to general reconnaissance examinations, especially in Kansas, Nebraska, southeastern Montana, New Mexico, western North Dakota, Oklahoma, South Dakota, northeastern Wyoming, and eastern Idaho. During the summer of 1923 examination was made of all lands included in applications pending at the beginning of the year in Arizona, California, Colorado, Idaho, Kansas, Nebraska, North Dakota, Oklahoma, Oregon, South Dakota, Utah, and Washington and of most of the lands included in such applications in Montana, New Mexico, and Wyoming - a total of about 2,000 applications.

Examination was also made to determine the value as public water reserves of tracts of land in Arizona, the Mohave Desert region in California, and Wyoming.

During the field season of 1924 work was begun early in June and at the end of the month had been completed in Arizona and New Mexico and was in progress in Colorado, Idaho, Montana, Oregon, South Dakota, Utah, and Wyoming.

\section{POWER AND IRRIGATION}

Arizona.-Hydraulic engineers were attached to the topographic survey party that traversed and mapped Colorado River from Lees Ferry, Ariz., to the lower end of Black Canyon. Surveys of all promising dam sites in that stretch were made under their supervision, and a report on the potential water power and storage capacities of the various dam sites and of the river below the mouth of the Green is in preparation. At the request of the Federal Power Commission examination of a project to develop power on Salt River was made and a report giving its results was prepared, and a report was made on a proposed power development on Black River.

Colorado.-A reconnaissance survey has been made on streams tributary to South Platte River north and west of Denver to determine the power value of lands set aside as power-site reserves. A similar survey is in progress in the Colorado River basin, a survey of Blue River from Dillon to its mouth having been completed and a survey of Eagle River from Redcliff to its mouth being under way. An examination and a report were made for the Federal Power Commission with respect to the power value of lands along Clear Creek in T. $3 \mathrm{~S}$., R. $74 \mathrm{~W}$. sixth principal meridian. Work has been started on a report on the utilization of Colorado River in Colorado and Utah to the mouth of Green River.

Idaho.-In order to determine the location and extent of special surveys for dam and reservoir sites along Clearwater River, Idaho, and to obtain information for incorporation in a report on the power value of that river and the adjacent lands, an engineer is working with a topographic party that is making surveys along the river. At the request of the Federal Power Commission an examination and report were made on a project to develop power on Crane Creek. Supplemental statistics were compiled from records of the State Department of Reclamation to show the amount and location of irrigated land in Snake River basin. A summary report has been prepared on the power resources of Snake River between Huntington, Oreg., and Lewiston, Idaho, to be published as Water-Supply Paper 520-C.

Montana.-An investigation of the use of water for power and irrigation and of the possible future use of water, principally for irrigation, in the drainage area of Missouri River above the mouth of Portage Creek (12 miles below Great Falls, Mont.), begun in June, 1923, was completed at the end of August. An examination was made to determine the irrigability of the bottom lands along Missouri River from Fort Benton, Mont., to the Montana-North Dakota State line.

New Mexico.- At the request of the Federal Power Commission an examination and a report were made on a project to develop power on Gila River in Grant County, N. Mex. 
Oregon.-In order to designate possible dam sites for detailed survey and to obtain information for reports on the power value of the streams and adjacent lands an engineer was detailed to a party making a survey of Klamath River from Keno, Oreg., to a point about 100 miles downstream, and two engineers are now detailed to parties surveying Umpqua River and its tributaries. Similar work that was being done in the Rogue River basin at the beginning of the year has been completed. An examination and a report were made for the Federal Power Commission with regard to the water-power resources of Trask, Nestucca, and Smith rivers. An examination is being made for the Federal Power Commission of a project to develop power on Crooked River. An office study, which was in progress during the previous year, of the water supply of streams in Oregon that flow to the Pacific Ocean between Klamath and Columbia rivers was completed.

Utah.-An investigation was made in the Escalante Desert, Utah, to determine the location of lands susceptible of irrigation from wells in a strip extending from a point 20 miles north of Milford, on the Los Angeles \& Salt Lake Railroad, southwestward, approximately parallel to the railroad, to the Utah-Nevada State line. Early in the year an engineer began to supervise a topographic survey of streams in the Uinta Basin and to make an examination of the region in order to report on the power value of the lands along the streams. This work is still in progress. Reports have been made for office use on the power value of lands in the Weber River basin included in powersite reserves, and some work has been done on similar reports for the San Rafael and Sevier River basins. Work has been continued on a report, to be published as a water-supply paper, on the utilization of Green River, in Wyoming, Colorado, and Utah.

Wyoming.-A reconnaissance survey of Sweetwater River, Wyo., begun in June, 1923, to determine the power value of the stream and adjacent lands between T. 28 N., R. 101 W., and T. 29 N., R. 85 W., a distance of more than 200 miles, was completed in July. A similar survey, covering a stretch of about 40 miles, was made of Encampment River and adjacent lands. At the request of the Federal Power Commission a brief investigation was made of the power value of lands lying along Torrey Lake outlet, a tributary of Wind River. (For report on Green River see Utah.)

\title{
IAAND-CLASSIFICATION BRANCH
}

\author{
ORGANIZATION AND PERSONNEL
}

At the end of the fiscal year the organization and technical personnel of the land-classification branch were as follows:

Chief, Herman Stabler.

Assistant chief, John D. Northrop.

Chief clerk, Elsie Patterson.

Division of mineral classification: J. D. Northrop, geologist, chief; C. D. Avery, mining engineer; W. W. Boyer, geologist; G. W. Holland, classifier.

Division of hydrographic classification: W. G. Hoyt, hydraulic engineer, chief. Power section: B. E. Jones, hydraulic engineer, chief; N. J. Tubbs, engineer; E. E. Jones and R. O. Helland, classifiers; Warren Oakey, assistant engineer. Irrigation section: J. F. Deeds, hydraulic engineer, chief; C. E. Nordeen, topographic engineer; W. N. White, classifier.

Division of homestead classification: A. E. Aldous, classifier, chief; J. G. Mathers, engineer; W. L. Hopper, classifier.

In addition, two engineers, R. W. Davenport and D. J. Guy, were detailed from the branch for duty with the Federal Power Commission during the entire year, and 8 classifiers on the rolls of the water-resources branch were added to the staff of the land-classification branch during the office season in connection with homesteadclassification work.

During the fiscal year there were 4 additions to the force and 6 separations. At its end the staff numbered 46, including the clerical force and employees detailed to the Federal Power Commission. 
During the year the land-classification branch performed the duties of the Geological Survey relating to "the classification of public lands" with which the Director of the Survey is charged by law. The field of its work is coextensive with the public domain of the United States, including Alaska.

The results of the work of the land-classification branch are utilized mainly in the preparation of orders for the withdrawal from entry, restoration to entry, classification, and designation of the public lands, of informative and advisory reports, and of recommendations for appropriate action concerning public lands, made chiefly to the General Land Office, the Secretary of the Interior, the Office of Indian Affairs, and the Federal Power Commission.

\section{FUNDS}

The current appropriation of $\$ 280,000$ for land classification prior to June 30,1924 , is an increase of $\$ 55,000$ over the appropriation for the preceding year but still $\$ 20,000$ below the appropriation available during the year ended June 30,1922. Of the sum appropriated about 35 per cent was utilized for administrative and office expenses and the remainder for field investigations.

\section{CORRESPONDENCE}

During the year 15,316 letters and petitions were received by the land-classification branch. In addition, 5,000 copies of miscellaneous correspondence were sent to the branch for its information and filing. The correspondence was made up largely of letters from the General Land Office to its local officers and of reports on the character of lands by its inspectors and examiners, copies of decisions rendered by the Department of the Interior, and copies of withdrawals and restorations recommended by the Bureau of Reclamation. Within the same period 12,054 letters were prepared by the branch. These figures show an average of 50 incoming letters and of 40 outgoing letters for each working day of the year.

\section{SUMMARY OF CASES}

The information supplied concerning land classification is furnished either in reports made in response to specific requests for action on cases presented or in the form of broad areal classifications. The following table, which gives a summary of the cases presented and acted on during the year, shows that reports were made on nearly 15,000 specific requests. The mere number of cases disposed of, however, is not a true index to the magnitude of the work done, for some cases require only a few minutes' consideration, whereas others require exhaustive study and research, extending 
over days or weeks, and some necessitate field investigations. The terms "gain" and "loss" in the table signify, respectively, decrease and increase in the number of cases pending.

General summary of cases involving land classification

\begin{tabular}{|c|c|c|c|c|c|c|c|c|}
\hline \multirow[b]{2}{*}{ Class of cases } & \multicolumn{6}{|c|}{ Record for fiscal year $1923-24$} & \multicolumn{2}{|c|}{$\begin{array}{l}\text { Record since } \\
\text { receipt of } \\
\text { first case }\end{array}$} \\
\hline & $\begin{array}{c}\text { Pend- } \\
\text { ing } \\
\text { July 1, } \\
1823\end{array}$ & $\begin{array}{c}\text { Re- } \\
\text { ceived } \\
\text { during } \\
\text { fiscal } \\
\text { year }\end{array}$ & Total & $\begin{array}{c}\text { Acted } \\
\text { on } \\
\text { during } \\
\text { fiscal } \\
\text { year }\end{array}$ & $\begin{array}{c}\text { Pend- } \\
\text { ing } \\
\text { June } \\
30, \\
1924\end{array}$ & $\begin{array}{c}\text { Gain } \\
\text { or loss } \\
\text { during } \\
\text { fiscal } \\
\text { year }\end{array}$ & $\begin{array}{c}\text { Re- } \\
\text { ceived }\end{array}$ & $\begin{array}{l}\text { Acted } \\
\text { on }\end{array}$ \\
\hline General Land Office requests.......... & \multirow[t]{2}{*}{483} & \multirow[t]{2}{*}{1,329} & \multirow[t]{2}{*}{1,812} & \multirow[t]{2}{*}{1,583} & \multirow[t]{2}{*}{229} & \multirow[t]{2}{*}{+254} & & \\
\hline $\begin{array}{l}\text { Applications for classification as to } \\
\text { mineral: } \\
\text { General }\end{array}$ & & & & & & & 3 & \\
\hline Coal & 18 & 13 & 31 & 22 & 9 & +9 & 756 & 747 \\
\hline Oil.. & 119 & 895 & 1,014 & 837 & 177 & -58 & 3,273 & 3,096 \\
\hline Phosphate. & 1 & & & & & -1 & & \\
\hline Applications for mineral permits.... & 619 & 6,607 & 7,226 & 6,019 & 1,207 & -588 & 27,336 & 26,129 \\
\hline Applications for mineral leases....... & 35 & 247 & 282 & 262 & 20 & +15 & 707 & 687 \\
\hline Applications for patent, potassium & 2 & & 2 & 1 & 1 & +1 & 17 & \\
\hline \multicolumn{9}{|l|}{$\begin{array}{l}\text { Federal Power Commission cases: } \\
\text { Preliminary permits }\end{array}$} \\
\hline $\begin{array}{l}\text { Preliminary permits } \\
\text { Licenses }\end{array}$ & \multirow{3}{*}{$\begin{array}{l}1 \\
1 \\
7\end{array}$} & \multirow[t]{2}{*}{6} & \multirow{2}{*}{$\begin{array}{l}7 \\
1 \\
7\end{array}$} & 6 & \multirow{2}{*}{$\begin{array}{l}1 \\
1\end{array}$} & & \multirow{2}{*}{$\begin{array}{l}46 \\
12 \\
61\end{array}$} & \\
\hline $\begin{array}{l}\text { Determinations under sec } 24 \\
\text { Anplications }\end{array}$ & & & & 7 & & +7 & & \\
\hline \multicolumn{8}{|l|}{ A pplications for reclassification as } & \\
\hline $\begin{array}{l}\text { to water resources } \\
\text { Applications for rights of way }\end{array}$ & \multirow{2}{*}{$\begin{array}{r}28 \\
4\end{array}$} & \multirow{2}{*}{$\begin{array}{r}6 \\
196 \\
8\end{array}$} & $\begin{array}{r}13 \\
224\end{array}$ & $\begin{array}{r}6 \\
192\end{array}$ & 32 & -4 & \multirow{2}{*}{$\begin{array}{r}634 \\
5,435\end{array}$} & \multirow{2}{*}{$\begin{array}{r}627 \\
5,403 \\
876\end{array}$} \\
\hline Irrigation project reports & & & 12 & 8 & 4 & & & \\
\hline $\begin{array}{l}\text { Applications under enlarged-home- } \\
\text { stead acts. }\end{array}$ & \multirow{2}{*}{578} & 585 & \multirow{2}{*}{1,163} & 822 & 341 & +237 & 54,907 & \multirow[t]{2}{*}{54,566} \\
\hline $\begin{array}{l}\text { Applications under stock-raising } \\
\text { homestead act }\end{array}$ & & 3,812 & & 4,929 & 1,837 & $+1,117$ & 109,282 & \\
\hline $\begin{array}{l}\text { Applications under ground-water } \\
\text { reclamation act }\end{array}$ & \multirow{3}{*}{$\begin{array}{r}45 \\
3 \\
1\end{array}$} & 58 & 103 & $x, 800$ & 1,001 & & & \\
\hline Indian Office requests for information. & & $\begin{array}{c}08 \\
4\end{array}$ & 7 & $\begin{array}{r}00 \\
6\end{array}$ & i & $\begin{array}{l}+8 \\
+2\end{array}$ & 9,490 & 9,489 \\
\hline Cases in national forests. & & 10 & 11 & 11 & & +1 & 293 & 293 \\
\hline & 4,906 & 13,782 & 18,688 & 14,782 & 3,906 & $+1,000$ & & \\
\hline
\end{tabular}

DIVISION OF MINERAL CLASSIFICATION

The work of the division of mineral classification involves, first, the withdrawal, classification, and restoration of public lands according to their mineral character; second, the solution of geologic and economic problems arising in connection with the leasing of mineral lands; and third, the preparation of reports showing the mineral character of specific lands for the information and guidance of other Government bureaus charged with the administration of the public-land and Indian land laws.

The approval of the potash-land leasing act in October, 1917, and of the general mineral-lands leasing act in February, 1920, opened to disposition the deposits of coal, oil, gas, phosphate, oil shale, sodium, and potash in some $50,000,000$ acres that were then embraced in outstanding mineral-land withdrawals, but it did not obviate the necessity for the classification of these lands and their restoration to the public domain. To this unfinished task the mineral division is devoting as much energy as is permitted by the limitations imposed by small personnel, inadequate geologic information, and pressure of more urgent work. The results accomplished in the fiscal year 
include a net increase of $1,812,685$ acres in the total area classified as coal land and of 4,105 acres in the total area classified as oil land and a net decrease of 2,998,210 acres in the area of outstanding coal withdrawals and of 421,723 acres in the area of outstanding petroleum withdrawals. No change was made during the year in areas previously withdrawn or classified as oil-shale land or in areas classified as phosphate land or included in potash reserves.

The gross areas already classified as valuable for mineral and those remaining withdrawn at the end of the fiscal year for certain minerals under the act of June 25, 1910, are shown in the following table:

Summary of outstanding mineral withdrawals and classifications, June 30, 1924, in acres

\begin{tabular}{|c|c|c|c|c|c|c|c|c|c|}
\hline \multirow[b]{2}{*}{ State } & \multicolumn{2}{|c|}{ Coal } & \multicolumn{2}{|c|}{ Oil } & \multicolumn{2}{|c|}{ Oil shale } & \multicolumn{2}{|c|}{ Phosphate } & \multirow[b]{2}{*}{$\begin{array}{l}\text { Potash } \\
\text { with- } \\
\text { drawn }\end{array}$} \\
\hline & $\begin{array}{l}\text { With- } \\
\text { drawn }\end{array}$ & $\begin{array}{l}\text { Classified } \\
\text { as coal } \\
\text { land }\end{array}$ & $\begin{array}{l}\text { With- } \\
\text { drawn }\end{array}$ & $\begin{array}{c}\text { Classi- } \\
\text { fled as } \\
\text { oil } \\
\text { land }\end{array}$ & $\begin{array}{l}\text { With- } \\
\text { drawn }\end{array}$ & $\begin{array}{c}\text { Classi- } \\
\text { fied as } \\
\text { oil-shale } \\
\text { land }\end{array}$ & $\begin{array}{l}\text { With- } \\
\text { drawn }\end{array}$ & $\begin{array}{l}\text { Classi- } \\
\text { fied as } \\
\text { phos- } \\
\text { phate } \\
\text { land }\end{array}$ & \\
\hline \multirow{13}{*}{$\begin{array}{l}\text { Alaska } \\
\text { Arizona } \\
\text { Arkansas } \\
\text { California } \\
\text { Colorado } \\
\text { Florida... } \\
\text { Idaho } \\
\text { Louisiana } \\
\text { Montana } \\
\text { Nevada } \\
\text { New Mexico } \\
\text { North Dakot } \\
\text { Oregon } \\
\text { South Dakot } \\
\text { Utah } \\
\text { Washington } \\
\text { W yoming }\end{array}$} & \multirow[b]{2}{*}{139,415} & \multirow[t]{2}{*}{56,993} & \multirow[b]{2}{*}{230,400} & & & & & & \\
\hline & & & & & & & & & \\
\hline & 17,603 & $\begin{array}{r}61,160 \\
8,720\end{array}$ & $1,178,392$ & & & & & & 90,518 \\
\hline & $4,241,552$ & $3,170,566$ & 222,977 & & 41,560 & 952,239 & & & \\
\hline & 4,761 & $\overline{603}$ & & $-\cdots$ & & 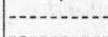 & $\begin{array}{r}84,842 \\
720,534\end{array}$ & 207 & \\
\hline & & & 466,990 & 4,105 & & & & 207,722 & $\cdots$ \\
\hline & $8,455,506$ & $8,419,065$ & $1,350,426$ & 42,097 & & & 287,883 & & \\
\hline & $\begin{array}{r}83,673 \\
5,158,680\end{array}$ & & & & 123 & & & & 39,422 \\
\hline & $\begin{array}{l}5,158,680 \\
5,954,364\end{array}$ & $\begin{array}{r}567,924 \\
11,178,286\end{array}$ & 84,894 & & & & & & $\cdots$ \\
\hline & 4,361 & 18,887 & & & & & & & \\
\hline & $4,258,519$ & $1,101,867$ & $1,870,627$ & & 86,584 & $2,705,035$ & 302,465 & & \\
\hline & $\begin{array}{r}691,801 \\
2,358,563\end{array}$ & $\begin{array}{r}141,444 \\
6,736,183\end{array}$ & 597,175 & & & 460,103 & 995,049 & 25,293 & 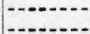 \\
\hline & $31,368,798$ & $31,715,791$ & $6,001,881$ & 46,202 & 128,267 & $4,117,377$ & $2,390,773$ & 293,015 & 129,940 \\
\hline
\end{tabular}

The contributions made to the administration of the mineral-lands leasing laws with respect to coal involve the determination whether a prospecting permit or a lease should be issued, and, if a lease is required, the establishment of a leasing unit consistent in area and content of coal with the mining operation to be undertaken and the recommendation of appropriate stipulations as to royalty, minimum investment, and minimum annual production. Those made with respect to oil and gas involve the definition of the "known geologic structure " of producing oil or gas fields as the primary distinction between leasing and prospecting areas, the determination of the structural relations of lands embraced in prospecting permit applications, and the classification of all tracts included in such applications that are involved in unperfected entries under the nonmineralland laws. Similar types of service involving decisions based on geologic evidence are rendered in the administration of the potashland leasing law and the sections of the general mineral-lands leasing law pertaining to phosphate, oil shale, and sodium. 
The following table summarizes the results of the year's work to the extent that they involve the consideration of specific applications for permit or lease rights under the leasing laws:

Applications made, acted on, and pending under the mineral-leasing acts, fiscal year 1923-24

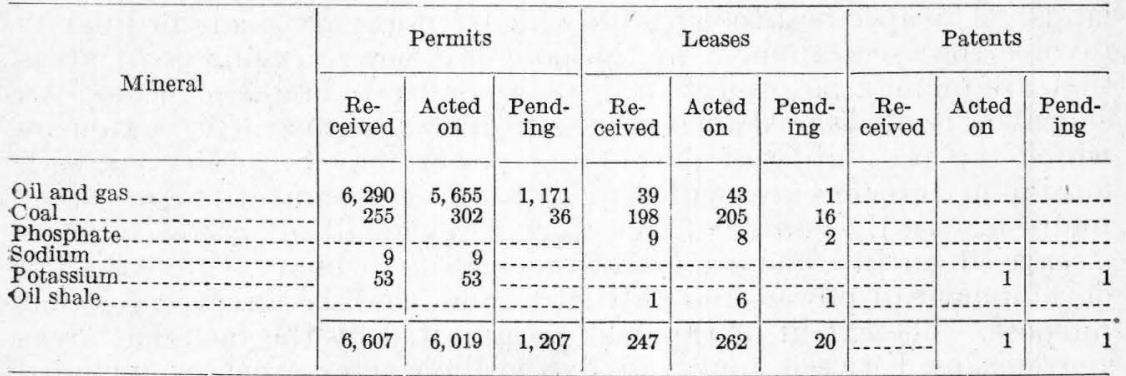

The work done under the leasing laws was restricted almost entirely to the designation of boundaries of the "known geologic structure" of producing oil and gas fields - that is, the designation of lands that are subject to lease only as distinguished from those on which prospecting permits may be granted. The results included definitions of the Hamilton (Moffat) and Wellington oil and gas fields, Colo.; the Aztec gas field, N. Mex.; the Alkali Butte and Notches oil fields and Boone Dome gas field, Wyo.; the Woodside gas field, Utah; and an extension of the Buena Vista Hills oil field, Calif.; and a revision of a definition of the Elk Hills field, Calif.

Reports made in response to requests of the General Land Office and the Office of Indian Affairs for information concerning the mineral character of specific lands have been kept up to date. There was a net reduction of 254 cases involving reports to the General Land Office and of 2 cases involving reports to the Office of Indian Affairs.

The work done involved the planning and financing of field surveys, both reconnaissance and detailed, which were made by the geologic and topographic branches.

The larger items of field work thus undertaken during the year to meet the specific needs of the land-classification branch and financed in whole or in part by allotments from funds appropriated for the classification of lands include (1) general geologic investigations in Blaine, Fergus, and Rosebud counties, Mont.; in Routt and Delta counties and along the east front of the Rocky Mountains, Colo.; in the Book Cliffs, Wasatch Plateau, and San Rafael districts, Utah; in the Powder River, Great Divide, and Snake River basins and the Rock Springs and Black Hills uplifts, Wyo.; in the Paradise Valley and Portneuf districts, Idaho; and in the Cold Bay region, Alaska; (2) detailed investigations of deposits of coal, oil, gas, and phosphate requisite to recommendations as to action on applications made under the leasing laws for lands in the States mentioned and in Oklahoma and New Mexico; and (3) core-drill prospecting of certain lands in Florida, undertaken to permit their classification with respect to phosphate. 


\section{DIVISION OF HYDROGRAPHIC CLASSIFICATION}

\section{POWER SECTION}

The work of the power section consists primarily in obtaining and making available for use in the administration of the public-land laws information as to the water-power resources of the public lands. The specific problems on which reports are made ordinarily involve the ascertainment of the potential power resources of areas that are or may be subject to disposal under public-land laws. An endeavor is made to determine the proper administrative action by which the possibility of developing power may be preserved with minimum interference with agricultural, transportation, or other interests. In the course of this work a review of all power reserves is carried on in order that all land having primary value for the development of power, and only such land, shall be reserved for that purpose. The extent of this task is indicated by the fact that areas. aggregating between four and five million acres are now included in power reserves whose use will be required for the development of about $15,000,000$ continuous horsepower.

In order that this information may be made substantially complete, areas not thoroughly surveyed are designated for examination by the field branches of the Survey. The larger items of field work done to obtain information for power classification undertaken and in progress during the year at the request of the land-classification branch and financed by allotments from funds appropriated for the classification of lands include (1) plan and profile surveys and power-site investigations on Colorado River through Glen, Marble, and Grand canyons in Arizona, Utah, and California; on Rogue River and its larger tributaries and on Umpqua River and its larger tributaries in Oregon; on Clearwater River in Idaho; on streams in the Uinta River basin. Utah; and on Klamath River in Oregon and California; (2) detailed studies of the possibilities of developing power on the western tributaries of South Platte River in Colorado, on Sweetwater and Encampment rivers in Wyoming, and on Madison, Beaverhead, Bighole, and Jefferson rivers and a part of South Fork of Flathead River in Montana.

The information obtained is indexed and incorporated in an inventory of water resources, which, when complete, will enable the Survey to give competent advice on short notice as to the manner: in which each tract of public land having value for power can be best used in connection with the development of water power and as to the relation of such use to other possible uses of the tract. Copies of many of the reports made on the power possibilities of the streams examined have been placed in the district offices of the Survey for public inspection, and notices of the availability of the reports have been sent to the press.

The work done in the section is briefly summarized in the following tables showing power-site reserves, outstanding water resources, and agricultural withdrawals and classifications, and in the table, already presented, giving a general summary of cases involving land classification. 
Pursuant to the instructions of the Secretary of the Interior dated August 24, 1916 (45 L. D. 326), permittees under the act of February 15, 1901 (31 Stat. 790), and grantees under the act of March 4, 1911 (36 Stat. 1253), to whom rights have been granted by the Secretary since January 1, 1913, were called upon for detailed reports of the operation or development of their power systems during the calendar year 1923. The total installation of the reporting companies is $1,574,000$. kilowatts, of which 1,271,000 kilowatts is installed at hydraulic plants. The total energy generated amounted to 5,910,000,000 kilowatt-hours, of which $5,245,000,000$ kilowatt-hours was generated by water power. The operating expenses of the companies generating 100,000,000 kilowatts or more (90 per cent of which was generated by water power), including taxes and depreciation, averaged 9.22 mills per kilowatt-hour installed. The gross income from the electrical operations of the same companies was 14.7 mills per kilowatt-hour of energy sold.

Power output of permittees and grantees, 1916-1923

\begin{tabular}{|c|c|c|c|c|}
\hline \multirow{2}{*}{ Year } & \multirow{2}{*}{$\begin{array}{l}\text { Number } \\
\text { report- } \\
\text { ing }\end{array}$} & \multirow{2}{*}{ Kilowatt-hours } & \multicolumn{2}{|c|}{ Increase or decrease } \\
\hline & & & Kilowatt-hours & Per cent \\
\hline 1916 & $\begin{array}{l}26 \\
32 \\
51 \\
57 \\
56 \\
59 \\
59\end{array}$ & $\begin{array}{l}1,200,000,000 \\
2,000,000,000 \\
3,200,000,000 \\
3,100,000,000 \\
4,200,000,000 \\
3,725,000,000 \\
4,947,000,000 \\
5,910,000,000\end{array}$ & $\begin{array}{r}+800,000,000 \\
+1,200,000,000 \\
-100,000,000 \\
+1,100,000,000 \\
-475,000,000 \\
+1,222,000,000 \\
+963,000,000\end{array}$ & $\begin{array}{r}+67 \\
+60 \\
-3 \\
+35 \\
-11 \\
+33 \\
+19\end{array}$ \\
\hline
\end{tabular}

Power-site reserves, in acres

[Includes all areas reserved or classified as valuable for power purposes and withheld subject to disposal only under the Federal water-power act of June 10, 1920 (41 Stat. 1053). Designations, classifications, and other types of reserves are included in the total areas without distinction]

\begin{tabular}{|c|c|c|c|c|c|c|}
\hline State & $\begin{array}{l}\text { Reserved } \\
\text { prior to } \\
\text { July 1, } \\
1923\end{array}$ & $\begin{array}{c}\text { Eliminated } \\
\text { prior to } \\
\text { July } 1 \\
1923\end{array}$ & $\begin{array}{c}\text { Reserves } \\
\text { outstanding } \\
\text { prior to } \\
\text { July } 1,1923\end{array}$ & $\begin{array}{c}\text { Reserved } \\
\text { during } \\
\text { fiscal } \\
\text { year }\end{array}$ & $\begin{array}{c}\text { Eliminated } \\
\text { during } \\
\text { fiscal } \\
\text { year }\end{array}$ & $\begin{array}{c}\text { Reserves } \\
\text { outstanding } \\
\text { June } 30 \\
1924\end{array}$ \\
\hline \multirow{2}{*}{\multicolumn{6}{|c|}{$\begin{array}{l}\text { Alabama.. } \\
\text { Alaska...- }\end{array}$}} & \\
\hline & & 520 & & 267 & & 167,988 \\
\hline Arizona.-. & $1,161,710$ & 105,194 & $1,056,516$ & 1,453 & 8,000 & $1,049,969$ \\
\hline Arkansas. & 28,469 & & 28,469 & 82 & & 28,551 \\
\hline California. & 953,072 & 18,252 & 934,820 & 42,282 & 1,007 & 976,095 \\
\hline Colorado & 342,406 & 48,254 & 294,152 & 11,103 & 6,879 & 298,376 \\
\hline $\begin{array}{l}\text { Florida - } \\
\text { Idaho }\end{array}$ & $\begin{array}{r}486 \\
440.936\end{array}$ & & 486 & & & $\begin{array}{r}486 \\
459\end{array}$ \\
\hline Michigan. & $\begin{array}{r}440,936 \\
1,240\end{array}$ & 172,467 & $\begin{array}{r}268,469 \\
1,240\end{array}$ & 9,943 & 11,753 & $\begin{array}{r}266,659 \\
1,240\end{array}$ \\
\hline Minnesota. & 12,841 & 532 & 12,309 & & & 12,357 \\
\hline Monta & 283,581 & 78,486 & 205,095 & 16,051 & 6,316 & 214,830 \\
\hline Nebraska. & 761 & & 761 & & & 761 \\
\hline Nevada & 300,422 & 28 & 300,142 & 328 & 200 & 300,270 \\
\hline New Mex & 215,181 & 6,53 & 208,644 & & 1,096 & 207,548 \\
\hline Oregon & 512,295 & 78,802 & 433,493 & 40,190 & 6,446 & 467,237 \\
\hline South Dakota & 12 & & 12 & & & \\
\hline Utah & 588,672 & 120,812 & 467,860 & 09017 & 2,228 & 468,678 \\
\hline $\begin{array}{l}\text { Washington. } \\
\text { Wisconsin. }\end{array}$ & $\begin{array}{r}178,441 \\
1,096\end{array}$ & 41,005 & 137,436 & 947 & 9,202 & $\begin{array}{l}151,181 \\
870\end{array}$ \\
\hline \multirow[t]{2}{*}{ Wyoming .......... } & 217,083 & 67,998 & 149,085 & 5,312 & 5,410 & 148,987 \\
\hline & $5,407,694$ & 739,365 & $4,668,329$ & 153,052 & 58,537 & $4,762,844$ \\
\hline
\end{tabular}


Summary of outstanding water-resources withdrawals and classifications, June 30, 1924, in acres

\begin{tabular}{|c|c|c|c|c|c|c|c|c|}
\hline \multirow{2}{*}{ State } & \multicolumn{5}{|c|}{ Power reserves } & \multirow{2}{*}{$\begin{array}{l}\text { Reser- } \\
\text { voir } \\
\text { with- } \\
\text { drawals }\end{array}$} & \multirow{2}{*}{$\begin{array}{l}\text { Public } \\
\text { water } \\
\text { with- } \\
\text { drawals }\end{array}$} & \multirow{2}{*}{$\begin{array}{l}\text { Ground- } \\
\text { water } \\
\text { reclama- } \\
\text { tion } \\
\text { designa- } \\
\text { tions }\end{array}$} \\
\hline & $\begin{array}{c}\text { With } \\
\text { drawals }\end{array}$ & $\begin{array}{l}\text { Classifi- } \\
\text { cations }\end{array}$ & $\begin{array}{l}\text { Designa- } \\
\text { tions }{ }^{a}\end{array}$ & $\begin{array}{l}\text { Miscel- } \\
\text { laneous }\end{array}$ & Total & & & \\
\hline Alabama & 120 & 190 & & 39 & 749 & & - & \\
\hline laska. & 93,415 & 3,478 & & 71,095 & 167,988 & & & \\
\hline Arizona.- & 302,208 & 37,182 & 528,245 & 182,334 & $1,049,969$ & 23,040 & 14,646 & \\
\hline $\begin{array}{l}\text { Arkansa } \\
\text { Californ }\end{array}$ & 22,354 & 1,590 & & 4,607 & 28,551 & & & \\
\hline Californi & 296,178 & 78,614 & & 601,303 & 976,095 & 1,160 & 167,371 & \\
\hline $\begin{array}{l}\text { Colorado } \\
\text { Florida. }\end{array}$ & 252,560 & 18,684 & & 27,132 & 298,376 & 1,728 & 1,740 & \\
\hline Idaho.... & 212,936 & 47,229 & & 6,494 & 266,659 & & 12,080 & $\cdots$ \\
\hline $\begin{array}{l}\text { Michigan } \\
\text { Minnesot }\end{array}$ & $\begin{array}{r}1,240 \\
12,309\end{array}$ & & & & & 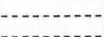 & & \\
\hline Munnesota & 141,521 & 51,271 & & 22,038 & 214,830 & 9,080 & 7,297 & (n)..... \\
\hline $\begin{array}{l}\text { Nebraska...... } \\
\text { Nevada....... }\end{array}$ & 761 & & & & & & & \\
\hline $\begin{array}{l}\text { Nevada.-...-. } \\
\text { New Mexico.. }\end{array}$ & $\begin{array}{l}27,492 \\
64,387\end{array}$ & 27,786 & & 244,992 & 300,270 & (n....... & 10,086 & $1,425,060$ \\
\hline North Dakota... & 64, & & 143,161 & & 201, & 1,569 & & \\
\hline $\begin{array}{l}\text { Oregon } \\
\text { South Dakota. }\end{array}$ & 395,215 & 24,356 & 15,891 & 31,775 & 467,237 & 10,619 & 15,951 & $\cdots$ \\
\hline $\begin{array}{l}\text { South Da } \\
\text { Utah.... }\end{array}$ & 445 , & 4,529 & & 37 & 8 & & $\begin{array}{r}240 \\
33,485\end{array}$ & \\
\hline Washingtc & 100,136 & 26,294 & 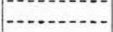 & 24,751 & 151,181 & 35,943 & 920 & . \\
\hline \multirow{2}{*}{ Wyoming } & 82,829 & 25,621 & & $\begin{array}{r}870 \\
40,537\end{array}$ & $\begin{array}{r}870 \\
148,987\end{array}$ & 1,714 & 81,505 & \\
\hline & $2,450,743$ & 346,824 & 687,297 & $1,277,980$ & $4,762,844$ & 84,933 & 353,637 & $1,425,0 \in 0$ \\
\hline
\end{tabular}

$a$ Designated and not otherwise withdrawn for power purposes.

\section{IRRIGATION SECTION}

The work of the irrigation section includes the classification of lands under the enlarged and stock-raising homestead laws as nonirrigable; the classification of lands under the Nevada ground-water reclamation act as nontimbered and not known to be susceptible of successful irrigation; the preparation of reports on the sufficiency of the water supply and general feasibility of irrigation projects that require some form of Federal approval in connection with the administration of public-land laws; and the initiation of withdrawal of lands for reservoir sites. Applications for classification are disposed of according to the results of examination made by the field branches of the Survey and information gathered from other sources showing water supply and adaptability to irrigation. Many applications involve the classification of large areas, and such broad classifications serve to govern action on new applications for the classification of land in the same areas. Thus broad field studies are planned in critical areas for execution by the field branches and financed by allotments from the funds appropriated for the classification of lands. During the year such studies were in progress at the headwaters of Missouri River in Montana, in the drainage areas of Red Rock, Beaverhead, Bighole, Jefferson, and Madison rivers; along Missouri River from Fort Benton to the Montana-North Dakota State line; and in Escalante Valley, Utah. Additional field studies were undertaken in scattered small tracts throughout the public-land States.

During the year the area of land designated under the Nevada ground-water reclamation act as a result of the work of the section was increased from $1,300,940$ to $1,425,060$ acres. Other results of 
the work are shown briefly in the tables relating to enlarged and stock-raising homestead designations and general summary of cases.

\section{Summary of enlarged-homestead designations, in acres}

A reas classified as arid and nonirrigable, residence by entrymen required, under act of Feb. $19,1909(35$ Stat. 639), applicable to Arizona, Colorado, Montana, Nevada, New Mexico, Oregon, Utah, Washingtor, W yoming; act of June 17, 1910 (36 Stat., 531), applicable to Idaho; act of June 13, 1912 (37 Stat., 132), applicable to California, North Dakota; act of Mar. 3, 1915 (38 Stat.. 953), applicable to Kansas; act of Mar. 4, 1915 (38 Stat., 1163), applicable to South Dakota. Areas classified as arid, nonirrigable, and lacking domestic water supply, residence by entrymen not required, under act of Feb. 19, 1909 (35 Stat., 639), applicable to Utah; act of June 17, 1910 (36 Stat., 531), applicable to Idaho.]

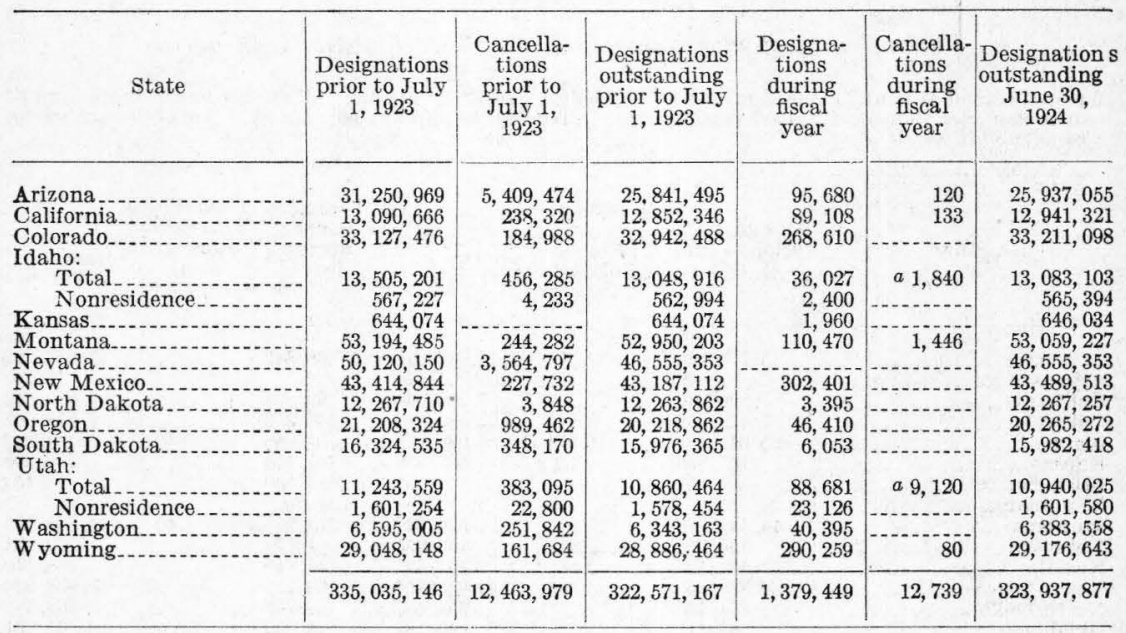

$a$ Previously designated under secs. 1-5, now designated under sec. 6.

\section{DIVISION OF HOMESTEAD CLASSIFICATION}

The stock-raising homestead law requires that prior to entry under its terms land shall be classified as nontimbered, nonirrigable, valuable chiefly for grazing and raising forage crops, and of such character that 640 acres is reasonably required for the support of a family. The division of homestead classification determines what lands shall be so classified, except as to irrigability, which is determined by the division of hydrographic classification. Field examination of individual tracts by the water-resources branch is planned by this division and financed by allotments from the funds appropriated for the classification of lands. Broad areal classification after general reconnaissance is made wherever practicable, in order to reduce the number of detailed field investigations to a minimum.

Under instructions of the Secretary of the Interior the division is cooperating with the Department of Agriculture in preparing a report on the agriculture and the utilization of land in the northern Great Plains region.

The work of this division includes also the reservation and restoration of tracts valuable for watering stock. During the year the additions to public water reserves embraced 125 acres in Arizona, 104,960 acres in California, 80 acres in Idaho, 360 acres in Montana, 70 acres in New Mexico, 1,640 acres in Oregon, 109 acres in Utah, and 40 acres in Wyoming, and the cancellations of such reserves included 5,777 acres in California, 80 acres in Colorado, 326 acres in 
Montana, 40 acres in Nevada, 120 acres in New Mexico, and 440 acres in Wyoming. The areas remaining reserved as public watering places at the end of the year are shown in the table of outstanding water-resources and agricultural withdrawals and classifications.

The following summary of stock-raising homestead designations shows in detail other features of the progress of the work of this division, which has been kept substantially current throughout the year.

Summary of stock-raising homestead designations, in acres

[Areas classified as nonirrigable, nontimbered, chiefly valuable for grazing and raising forage crops, and of such character that 640 acres are reasonably required for the support of a family. Act of December 29 , 1916 (39 Stat. 862)]

\begin{tabular}{|c|c|c|c|c|c|c|}
\hline State & $\begin{array}{c}\text { Designations } \\
\text { prior to July } \\
1,1923\end{array}$ & $\begin{array}{c}\text { Cancella- } \\
\text { tions } \\
\text { prior to } \\
\text { July } 1 \text {, } \\
1923\end{array}$ & $\begin{array}{l}\text { Designations } \\
\text { outstanding } \\
\text { prior to July } \\
1,1923\end{array}$ & $\begin{array}{l}\text { Designa- } \\
\text { tions } \\
\text { during } \\
\text { fiscal } \\
\text { year } 1924\end{array}$ & $\begin{array}{c}\text { Cancella- } \\
\text { tions } \\
\text { during } \\
\text { fiscal } \\
\text { year } 1924\end{array}$ & $\begin{array}{c}\text { Designations } \\
\text { outstanding } \\
\text { June } 30, \\
1924\end{array}$ \\
\hline $\begin{array}{l}\text { Arizona } \\
\text { Arkansas } \\
\text { California. } \\
\text { Colorado. } \\
\text { Idaho } \\
\text { Kansas } \\
\text { Michigan } \\
\text { Minnesota }\end{array}$ & $\begin{array}{r}13,779,110 \\
1,120 \\
7,529,930 \\
7,478,952 \\
5,041,035 \\
107,859 \\
2,951\end{array}$ & $\begin{array}{r}832,200 \\
9,240 \\
1,134 \\
\hdashline \\
\hdashline\end{array}$ & $\begin{array}{r}12,946,910 \\
1,120 \\
7,529,930 \\
7,469,712 \\
5,039,901 \\
107,859 \\
2,951\end{array}$ & $\begin{array}{r}88,312 \\
89,933 \\
469,253 \\
104,986 \\
1,440 \\
500\end{array}$ & 640 & $\begin{array}{r}13,035,222 \\
1,120 \\
7,619,863 \\
7,938,965 \\
5,144,247 \\
109,299 \\
3,451\end{array}$ \\
\hline $\begin{array}{l}\text { Montana. } \\
\text { Nebraska } \\
\text { Nevada } \\
\text { Now Mexico Dakota. } \\
\text { Oklahoma } \\
\text { Oregon } \\
\text { South Dakota } \\
\text { Utah } \\
\text { Washington } \\
\text { Wyoming. }\end{array}$ & $\begin{array}{r}14,543,978 \\
160,255 \\
434,125 \\
30,839,355 \\
354,430 \\
67,111 \\
6,036,989 \\
6,437,247 \\
1,080,482 \\
638,533 \\
19,325,090\end{array}$ & $\begin{array}{r}17,041 \\
2,800 \\
600 \\
2,408 \\
550 \\
880 \\
1,134 \\
4,934\end{array}$ & $\begin{array}{r}14,526,937 \\
160,255 \\
431,325 \\
30,838,755 \\
354,430 \\
67,111 \\
6,034,581 \\
6,436,697 \\
1,079,602 \\
637,399 \\
19,320,156\end{array}$ & $\begin{array}{r}277,278 \\
1,779 \\
36,815 \\
160,171 \\
8,755 \\
6,090 \\
106,264 \\
17,427 \\
96,748 \\
9,550 \\
326,140\end{array}$ & 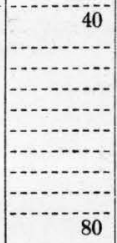 & $\begin{array}{r}14,804,175 \\
162,034 \\
468,140 \\
30,998,926 \\
363,185 \\
73,201 \\
6,140,845 \\
6,454,124 \\
1,176,350 \\
646,949 \\
19,646,216\end{array}$ \\
\hline & $113,858,552$ & 872,921 & $112,985,631$ & $1,801,441$ & 760 & $114,786,312$ \\
\hline
\end{tabular}

\section{PUBLICATION BRANCH}

\section{DIVISION OF BOOK PUBLICATION}

\section{SECTION OF TEXTS}

During the year 27,981 pages of manuscript were edited and prepared for printing, and proof sheets comprising 2,306 galley proofs and 15,928 page proofs were read and corrected. Indexes were prepared for 25 publications, covering 4,455 pages. Copy and proof or stencils for 620 pages of multigraph and mimeograph matter were read. The book publications of the year are listed and abstracted on pages 8-13.

At the end of the fiscal year $\breve{5}$ persons were employed in this section. The water-resourees branch has continued to render special assistance in preparing copy and reading proof.

\section{SECTION OF ILIUSTRATIONS}

The number of drawings prepared was 4,442, including 166 maps, 1,031 sections and diagrams, 349 photographs, and 2,896 paleontologic drawings; 119 miscellaneous jobs were also done by the section. The 
illustrations transmitted to accompany manuscripts numbered 873 , to be reproduced by chromolithography, photolithography, halftone, zinc etching, and cuts already engraved. The number of proofs received and examined was 575 . At the end of the year material for illustrating 37 reports was on hand. The section now consists of 10 employees.

DIVISION OF MAP EDITING

\section{SECTION OF GEOLOGIC EDITING OF MAPS AND ILLUSTRATIONS}

During the year 5 geologic folios were in hand. Four of these were completed and published. (See p. 13.) The maps of the Black Hills folio were printed and part of the text was in galiey proof at the end of the year. The boundaries and letter symbols for the geologic map of Wyoming were drawn and prepared for photolithography. The boundaries and letter symbols of the geologic map of Arizona were prepared and engraved and transferred to stone, and the color sheets were prepared. The geologic map of Oklahoma, which is being compiled by others, was examined in cooperation with the compilers. The compilation of the geologic map of Texas was begun, and work was done on the geologic map of the United States. Illustrations for 32 reports of the Survey were critically examined and edited in the section. Some of these illustrations were drawn in the section, and several geologic maps for reports not yet transmitted were compiled and drawn in the section.

\section{SECTION OF INSPECTION AND EDITING OF TOPOGRAPHIC MAPS}

During the year 90 topographic maps were edited and transmitted for engraving, 222 published topographic maps were edited for reprint, 54 plan and profile river-survey sheets were edited for photolithography, 3 miscellaneous maps were edited for engraving or photolithography, and 249 maps were edited as illustrations for Survey reports, a total of 618 maps edited. First, second, combined, and woodland proofs of engravings for new topographic maps and reprints numbering 424 and proofs of maps reproduced by photolithography numbering 189 were read. At the end of the year 87 new topographic maps were in process of engraving and printing. Index maps for 18 State circulars were revised and proofs corrected.

\section{DIVISION OF DISTRIBUTION}

During the year the division received 114 new books and pamphlets, 2 reprinted books and pamphlets, 4 new geologic folios, 12 new geologic maps, 92 new or revised topographic and other maps, and 203 reprinted topographic and other maps. A number of special pamphlets and forms prepared for administrative use were also received and distributed. The total units of all publications received numbered 351,107 books and pamphlets, 15,485 geologic folios, 1,777 geologic maps, and 970,804 topographic and other maps, a grand total of $1,339,173$.

The division distributed 521,548 books, 16,681 folios, 923 copies of the World Atlas (555 of Part I and 368 of Part II), and 735,573 maps, a total of $1,274,725$, of which 8,263 folios, 692 copies of the World Atlas (457 of Part I and 235 of Part II), and 608,436 maps 
were sold. The sum received and deposited in the Treasury from the sale of publications was $\$ 41,690.31$, including $\$ 39,383.01$ for topographic and geologic maps, $\$ 1,329.10$ for geologic folios, and $\$ 978.20$ for copies of the World Atlas. In addition, $\$ 990.19$ was paid by other establishments of the Federal Government for maps or folios furnished by request. The total receipts, therefore, were $\$ 42,680.50$. The division received and answered 87,502 letters.

\section{DIVISION OF ENGRAVING AND PRINTING}

\section{TOPOGRAPHIC MAPS AND GEOLOGIC FOLIOS}

During the fiscal year 70 new topographic maps were engraved and printed, including a revised edition of the Brownsville (Kentucky) map, and 22 new maps were photolithographed and printed, making a total of 92 new maps printed and delivered. Corrections were engraved on the plates for 214 maps. Photolithographic reprints of editions of 193 topographic maps and of 10 corrected State and other maps were delivered. In addition, 32 new topographic maps were engraved but had not been printed by June 30, and the engraving for 9 more new topographic maps was nearly completed.

Of new and reprinted maps 295 different editions, amounting to 970,804 copies, were delivered.

Four new geologic folios were printed, in editions amounting to 15,485 copies. Twelve extra geologic maps of these folios, numbering 1,777 copies, were also delivered.

\section{OTHER GOVERNMENT MAP PRINTING}

A large amount of work was done for the Government Printing Office, for the office of the Secretary of the Interior, for the Bureau of Mines, Bureau of Reclamation, Bureau of Education, National Park Service, Office of Indian Affairs, General Land Office, Bureau of Public Roads, Bureau of Plant Industry, Bureau of Agrieultural Economics, Forest Service, Bureau of Standards, Bureau of Foreign and Domestic Commerce, Bureau of Lighthouses, Department of Labor, Department of Justice, Department of State, War Department, Post Office Department, Interstate Commerce Commission, United States Coal Commission, Federal Power Commission, International Boundary Commission, Alaskan Engineering Commission, Commission of Fine Arts, Federal Fuel Distributor, Federal Board for Vocational Education, and Veterans' Bureau. This work done for other branches of the Government included many reprints, and the charges for it amounted to about $\$ 120,000$, for which the appropriation for engraving and printing geologic maps was reimbursed by transfer of credit on the books of the Treasury Department. Work amounting to $\$ 4,643.79$ was done on a topographic map of Arizona for the Bureau of Mines of that State, the employees of the Survey having been placed on an Arizona pay roll.

'Transfer impressions numbering 264 were made during the year, including 125 furnished to contracting lithographic printers on requisition of the Government Printing Office, 103 furnished to private firms, 9 furnished under cooperative agreements to State geological surveys, and 27 furnished to the War Department. Other miscellaneous work was done for the Anthracite Bureau of In- 
formation, Idaho Bureau of Mines, Des Moines Joint Stock Land Bank, The Military Engineer, Rider's Guides, and the World Book Co. The amount turned over to miscellaneous receipts from this work was $\$ 497.79$.

Of contract and miscellaneous work of all kinds, 3,667,916 copies were printed. Including topographic maps and geologic folios, a grand total of $4,655,982$ copies were printed and delivered. As most of this work was in colors, involving many separate printings, the total number of impressions was about 23,000,000.

\section{PHOTOGRAPHIC IABORATORY}

The output of the photographic laboratory consisted of 14,008 negatives (1,644 wet, 246 paper, 3,026 dry, 4,550 field negatives developed, and 4,542 photolithographic negatives), 1,609 lantern slides, 111,037 prints $(72,165$ maps and diagrams, 34,518 photographs for illustrations, and 4,354 rectigraphs), 3,744 zinc plates, 270 zine etchings, 105 celluloid prints, 341 lantern slides colored, and 1,387 prints mounted.

\section{ADIMINISTRATIVE BRANCH}

\section{EXECUTIVE DIVISION}

During the year 138,310 pieces of mail, of which 2,535 were registered, were opened and referred, and 1,000 letters and cards were received in connection with the revision of mailing lists. In addition 210,051 letters were received directly by other divisions, making a total of 348,361 , an increase of 3 per cent over the total in 1923. Of the letters opened in this division 19,624 contained money remitted for Survey publications. The ordinary letters mailed through the division numbered 95,623 , the registered letters and packages 17,990, and the form letters, etc. (addressograph section), 475,000. In addition 294,566 pieces of mail were sent out directly from other divisions. The total number of outgoing pieces of mail from the Geological Survey was 883,179.

During the year 3,505 pieces of freight and express were handled, 1,294 outgoing and 1,211 incoming.

The Secretary's appointees at the end of the fiscal year numbered 928, 13 more than at the end of the fiscal year 1923. The total number of changes in personnel was 489, which included 170 appointments, 157 separations, and 162 miscellaneous changes.

During the calendar year 192316,663 days of annual leave and 4,165 days of sick leave were granted-about 72 per cent of the annual leave and 18 per cent of the sick leave that could have been granted to an average of 768 employees entitled to leave. Leave without pay and furlough amounting to 5,176 days was also granted.

The clerical personnel of the division consisted of 29 employees, 15 of whom were employed in the addressograph section. In addition there were 2 general laborers, a chief messenger, and 9 messengers, a total of 40 .

$$
11580-24-6
$$




\section{DIVISION OF SCIENTIFIC AND TECHNICAL EQUIPMENT}

The work of the division of scientific and technical equipment consists of the receipt, custody, and shipment of field property, the repair of instruments, the inspection and repair of all electric apparatus, and the execution of cabinet and carpenter work. Records are kept of all camp equipment, such as livestock, automobiles, and instruments. In this work 7 persons were employed. The express and freight handled during the year weighed approximately 77,000 pounds.

\section{LIBRARY}

The accessions to the library numbered 13,962 books, pamphlets, and periodicals and 693 maps. The recorded loans were 6,762 books and 292 maps, not including those used by 12,908 readers who consulted the library in person. The catalog was increased by the addition of 7,920 cards. In accordance with the cooperative cataloging arrangement 469 title entries were furnished to the Library of Congress for printing, the proof reading for which involved 111 galleys.

The correspondence, consisting of 2,225 letters written and 2,356 received, concerned chiefly the exchange of publications. The foreign articles and letters translated for other divisions of the Survey numbered 230. There were 1,200 books collated and prepared for binding and 1,589 newly bound books accessioned and labeled.

Continued calls are received from other parts of the country for the loan of publications that are available only in this library. The library is cooperating in the compilation of a union list of serials in the libraries of the United States, which is to be published under the auspices of the American Library Association.

The bibliography and index of geologic literature on North America, 1785-1918, were proof read and have been issued as Bulletins 746 and 747. The bibliography of North American geology for 1921-22 (Bulletin 758) was prepared and proof read.

\section{DIVISION OF ACCOUNTS}

Condensed statements covering the expenditures from Federal funds during the year are given on the following pages. The amounts expended by States for cooperative work are set forth in the reports of the field branches. 
Amounts appropriated for and expended by the United States Geological Survey pertaining to the fiscal year ended June 30, 1924a

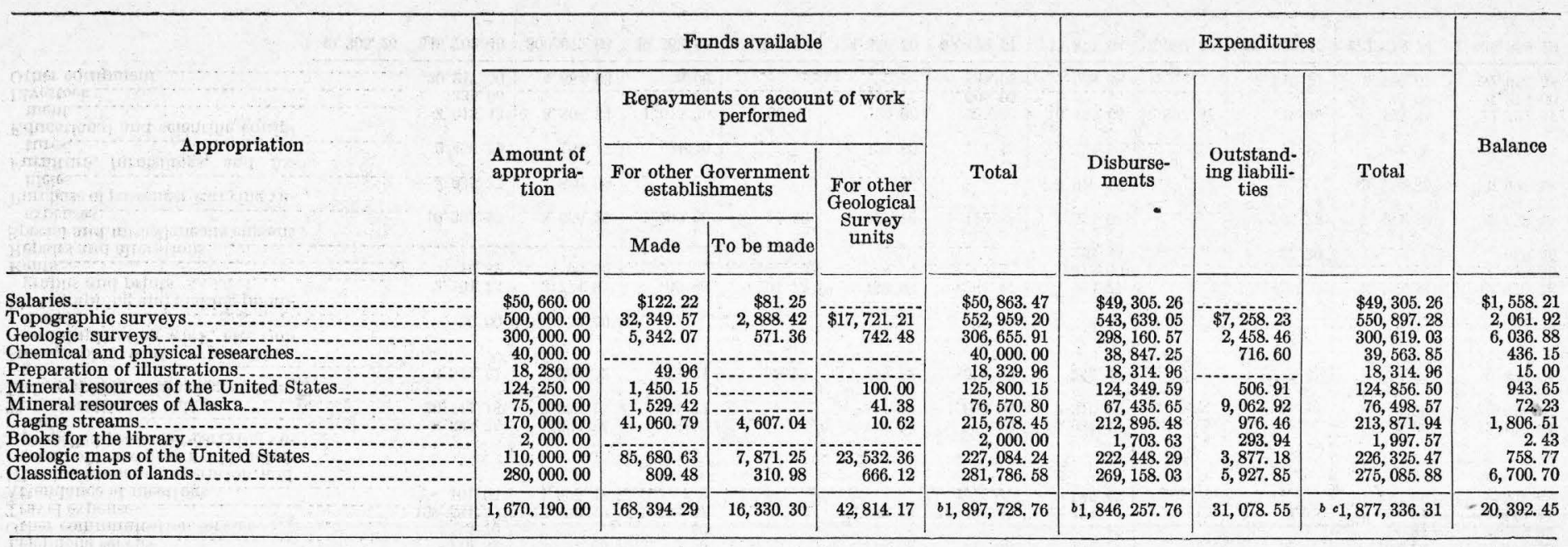

- In addition to these appropriations, items of $\$ 110,000$ for printing and binding Survey publications and $\$ 10,000$ for miscellaneous printing and binding were contained in the appropriation for that purpose, the accounts for which, however, were not kept in the Geological Survey. There was also an allotment of $\$ 4,280.70$ for miscellaneous supplies from the appropriation for contingent expenses of the Interior Department.

Included in this amount is $\$ 42,814.17$ covering work performed by Survey units for other Survey units, necessarily reported in combining totals but otherwise a duplication.

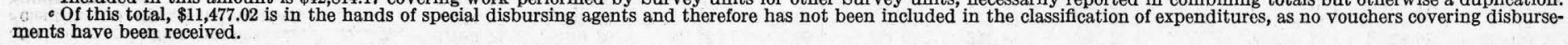




\begin{tabular}{|c|c|c|c|c|c|c|c|c|c|c|c|c|}
\hline Object of expenditure & $\begin{array}{l}\text { Geological } \\
\text { Survey } \\
\text { salaries }\end{array}$ & $\begin{array}{l}\text { Topo- } \\
\text { graphic } \\
\text { surveys }\end{array}$ & $\begin{array}{l}\text { Geologic } \\
\text { surveys }\end{array}$ & $\begin{array}{l}\text { Chemical } \\
\text { and phys- } \\
\text { ical } \\
\text { researches }\end{array}$ & $\begin{array}{l}\text { Prepara- } \\
\text { tion of } \\
\text { illustra- } \\
\text { tions }\end{array}$ & $\begin{array}{l}\text { Mineral } \\
\text { resources } \\
\text { of the } \\
\text { United } \\
\text { States }\end{array}$ & $\begin{array}{c}\text { Mineral } \\
\text { resources } \\
\text { of } \\
\text { Alaska }\end{array}$ & $\begin{array}{l}\text { Gaging } \\
\text { streams }\end{array}$ & $\begin{array}{l}\text { Books } \\
\text { for the } \\
\text { library }\end{array}$ & $\begin{array}{l}\text { Geologic } \\
\text { maps of the } \\
\text { United } \\
\text { States }\end{array}$ & $\begin{array}{l}\text { Classifi- } \\
\text { cation of } \\
\text { lands }\end{array}$ & Total \\
\hline 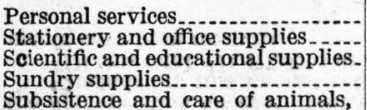 & $\$ 49,305.26$ & $\begin{array}{r}\$ 353,786.74 \\
1,883.71 \\
844.85 \\
4,998.48\end{array}$ & $\begin{array}{r}\$ 249,342.71 \\
870.20 \\
1,767.13 \\
555.06\end{array}$ & $\begin{array}{r}\$ 32,746.56 \\
87.36 \\
2,159.11 \\
106.70\end{array}$ & $\begin{array}{r}\$ 17,992.18 \\
1.50 \\
43.64\end{array}$ & $\begin{array}{r}\$ 118,160.15 \\
213.05 \\
353.91 \\
55.31\end{array}$ & \begin{tabular}{|r|}
$\$ 52,076.43$ \\
234.83 \\
247.03 \\
103.31
\end{tabular} & $\begin{array}{r}\$ 159,819.81 \\
903.79 \\
1,216.77 \\
2,088.99\end{array}$ & & $\begin{array}{r}\$ 167,537.72 \\
39,626.10 \\
1,968.64 \\
6,739.49\end{array}$ & $\begin{array}{r}\$ 194,217.67 \\
1,229.97 \\
214.46 \\
898.11\end{array}$ & $\begin{array}{r}\$ 1,394,985.23 \\
45,050.51 \\
8,815.54 \\
15,545.45\end{array}$ \\
\hline $\begin{array}{l}\text { Subsistence and care of animals, } \\
\text { and storage and care of vehicles. } \\
\text { Telegraph service. }\end{array}$ & & 1,415. 05 & 739. 24 & & & & & & & & 150.16 & $2,304.45$ \\
\hline $\begin{array}{l}\text { Telegraph service } \\
\text { Telephone service }\end{array}$ & & $\begin{array}{l}627.74 \\
119.32\end{array}$ & $\begin{array}{r}170.58 \\
22.65\end{array}$ & $\begin{array}{l}1.79 \\
3.50\end{array}$ & & $\begin{array}{l}882.87 \\
145: 08\end{array}$ & $\begin{array}{r}112.59 \\
11.08\end{array}$ & $\begin{array}{l}248.34 \\
453.29\end{array}$ & & 4.82 & $\begin{array}{l}220.50 \\
104.66\end{array}$ & $\begin{array}{r}2,268.23 \\
859.58\end{array}$ \\
\hline $\begin{array}{l}\text { Other communication service.-.. } \\
\text { Travel expenses... }\end{array}$ & $\cdots$ & $\begin{array}{r}5.70 \\
109.564 .39\end{array}$ & & $\begin{array}{r}0.00 \\
.60\end{array}$ & -... & & & 7.15 & & & 14.87 & $\begin{array}{r}859.58 \\
28.32\end{array}$ \\
\hline $\begin{array}{l}\text { Travel expenses. } \\
\text { Attendance at meetings }\end{array}$ & & $\begin{array}{r}109,564.39 \\
101.05\end{array}$ & $\begin{array}{r}18,839.19 \\
1,605.48\end{array}$ & $1,588.97$ & & $2,669.00$ & $10,428.80$ & $\begin{array}{r}21,434.57 \\
565.42\end{array}$ & & 53.88 & $\begin{array}{r}41,463.31 \\
319.68\end{array}$ & $\begin{array}{r}206,042.11 \\
2,591.63\end{array}$ \\
\hline $\begin{array}{l}\text { Hire, maintenance, operation, and } \\
\text { repair of horse-drawn and motor- } \\
\text { propelled passenger-carrying ve- }\end{array}$ & & & & & & & & & & & & \\
\hline Tracles & & $\begin{array}{r}8,338.75 \\
20,111.18\end{array}$ & $\begin{array}{l}1,396.84 \\
3,360.19\end{array}$ & $\begin{array}{r}6.00 \\
541.77\end{array}$ & & $\begin{array}{l}146.38 \\
157.16\end{array}$ & $\begin{array}{r}96.00 \\
1,633.04\end{array}$ & $\begin{array}{l}3,981.41 \\
2,310.83\end{array}$ & & 48. 40 & $\begin{array}{l}5,170.96 \\
8,456.20\end{array}$ & $\begin{array}{l}19,136.34 \\
36,618.77\end{array}$ \\
\hline Lithographing, engraving, and en- & & $6,348.51$ & $1,886.52$ & 13. 24 & 8. 29 & 499. 53 & 529. 93 & 742. 98 & & 215. 21 & 50.83 & $10,495.04$ \\
\hline $\begin{array}{l}\text { Stenographic work, typewriting, } \\
\text { and duplicating work, etc. (job } \\
\text { work) }\end{array}$ & & 30.00 & 52.50 & & & & 30.00 & 6.54 & & & 3. 35 & 122. 39 \\
\hline $\begin{array}{l}\text { Photographing and making photo- } \\
\text { graphs and prints.. } \\
\text { Rents. }\end{array}$ & & $\begin{array}{r}2,101.73 \\
19.32\end{array}$ & $\begin{array}{r}5,774.91 \\
96.90\end{array}$ & 60.86 & 194.75 & $\begin{array}{r}189.96 \\
8.14\end{array}$ & 281.47 & $\begin{array}{r}903.77 \\
1,815.00\end{array}$ & & & $3,463.33$ & $\begin{array}{r}12,970.78 \\
1,939.36\end{array}$ \\
\hline $\begin{array}{l}\text { Repairs and alterations } \\
\text { Special and miscellaneous current }\end{array}$ & & & & & & & & 223.35 & & 427.30 & & 650.65 \\
\hline $\begin{array}{l}\text { expenses } \\
\text { Purchase of passenger-carrying ve- }\end{array}$ & & $10,395.99$ & $3,650.39$ & $1,202.60$ & 14.60 & 927.16 & $1,142.38$ & $1,554.94$ & & $2,765.75$ & $7,854.33$ & $29,508.14$ \\
\hline $\begin{array}{l}\text { hicles } \\
\text { Furniture, furnishings, and fix- }\end{array}$ & & $2,035.37$ & $1,830.00$ & & & & & $3,926.16$ & & & $2,136.35$ & $9,927.88$ \\
\hline $\begin{array}{l}\text { tures } \\
\text { Educational and scientific equip- }\end{array}$ & & $2,406.59$ & 166. 17 & 21. 40 & & 428.80 & 751.13 & 134.80 & & 41.96 & 592.99 & $4,543.84$ \\
\hline $\begin{array}{l}\text { ment. } \\
\text { Livestock }\end{array}$ & & $\begin{array}{r}3,015.43 \\
335.00\end{array}$ & $3,808,34$ & $1,015.39$ & 60.00 & 20.00 & $\begin{array}{r}255.46 \\
005.00\end{array}$ & $10,495.65$ & $\$ 1,997.57$ & $1,149.49$ & 305. 34 & 22, 122.67 \\
\hline Other equipment.... & & $20,217.50$ & $4,684.03$ & 8.00 & 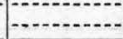 & (1) & 485.09 & $1,038.38$ & $\ldots$ & $5,746.71$ & $5,776.67$ & $37,956.38$ \\
\hline & $49,305.26$ & $548,702.40$ & $300,619.03$ & $39,563.85$ & $18,314.96$ & $124,856.50$ & $69,423.57$ & $213,871.94$ & $1,997.57$ & $226,325.47$ & $272,878.74$ & $1,865,859.29$ \\
\hline
\end{tabular}




\section{INDEX}

Page

Accounts division.

Administrative branch

$80-82$

Air-route maps. 79-82

Alabama, surveys and reports

$13,28,52$

Alaska, surveys and reports......... 3, 14, 40,45-47

Appropriations and expenditures. $23,24-25,45-46,49,56-57,68,80-82$

Arizona, surveys and reports..... 14, 28-29, 54, 62, 66

Arkansas, surveys and reports.............. 29, 62

Asia, fossils examined

29,62

California, surveys and reports . . 14-16, 29, 55, 62-63

Canada, specimens examined.

Central America, fossils examined

Chemical research.

Clarke, F. W., chemical research.. 2-3, 6-7, 43-44, 64

Colorado, surveys and reports....... $29-30,54,66$

Colorado Canyon survey

Connecticut, surveys and reports $\ldots . . . .9,30,52,63$

Cooperation with States and with other

$$
\text { Federal bureaus. }
$$

$25-26,49,57-59,78-79$

$5,68,79$

Correspondence

Director, work and addresses............. 6, 7-8

District of Columbia, field work

Editing.

$7-78$
30

Editing _._................................... 51, 76-77

Europe, fossils examined

Executive division

Florida, surveys and report

Geologic surveys

41

Georgia, surveys and reports

Hawaii, surveys and reports...............

年

Idaho, surveys and reports ........... 16, 31, 54, 63, 66

Illinois, surveys and reports............ 16-17, 31,53

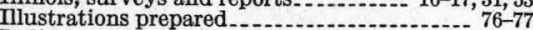

Indiana, surveys

Instruments and equipment.......... 80

Iowa, surveys ......................... 31,54

Irrigation surveys..................... $66-67,74-75$

Kansas, surveys and reports

Kentucky, surveys and reports......... 17, 32, 53, 54

Land classification......................... 4, 65-76

Library . . . .

Louisiana, surveys and reports............ 32

$1 \overline{7}, 32,52$

Maps edited and printed
Page

Massachusetts, surveys and reports .......... 32,53

Mexico, fossils examined

Michigan, surveys and reports ........ 18, 32-33

Mineral-resources division ___ 2, 41-43

Minnesota, geologic work

Mississippi, surveys and reports.......... 18, 33

Missouri, surveys and reports....... $17,18,33,53,54$

Montana, surveys and reports... $18,33-34,54,63,66$

Naval Petroleum Reserve No. 4. ....... 5-6, 46, 47

Nebraska, study of rocks ....................... 34

Nevada, surveys and reports................. 34

New Hampshire, geologic work

New Jersey, surveys

New Mexico, surveys and reports....... $35,63,66$

New York, surveys and reports ........ 18-19, 35, 53

North Carolina, surveys and reports .......... 35

North Dakota, surveys and reports........ 35, 63-64

Ohio, surveys and reports

Oklahoma, surveys and reports $. . . . . . . . .35-36,64$

Oregon, surveys and reports... $16,19,36,55-56,64,67$

Pennsylvania, surveys and reports....... 19,36,53

Photographic work

Physical research

Potash investigations

Power-resources surveys......... 64-65, 66-67, 72-74

Publications prepared and issued...... 4, 8-22, 76-78

Resignations _................................ 24, 41

Rhode Island, surveys..................... 53

South America, fossils examined..........
South Carolina, surveys and reports..... 41

South Dakota, geologic reports............. 36-37

Summary of the work of the year............ 1-5

Tennessee, surveys and reports .......... 37,52,53

Texas, surveys and reports...... 20,37-38, 54-55, 64 Topographic branch, work and publications. 38 ,

Topographic surveys, map showing areas covered 50

Utah, surveys and reports........................... $38,55,67$ Vermont, surveys and reports .......... 20,38, 53 Virginin, surveys and reports........ $21,38,53,64$ Washington, surveys and reports... $20,38-39,56,64$ Water-resources, branch West Indies, fossils examined............. 41

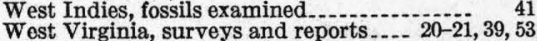
Wisconsin, surveys and reports......... 17, $22,39,54$ Wyoming, surveys...................... $39-40,55,67$ 